\title{
Detailed genetic analysis of faba bean (Vicia faba L.) winter-hardiness and related traits
}

Doctoral Dissertation

Submitted for the Ph. D. degree in the Faculty of Agricultural Sciences,

Georg-August-University Göttingen,

Germany

by

Mustapha Arbaoui

born in Rabat, Morocco

Göttingen, May 2007 
D7

1. Name of referee: Prof. Dr. Wolfgang Link

2. Name of co-referee: Prof. Mohammed Sadiki

Date of dissertation: 24.05.2007 
To my dear family 


\section{Table of contents}

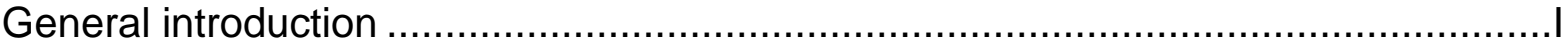
Literature review ........................................................................................... 1 -

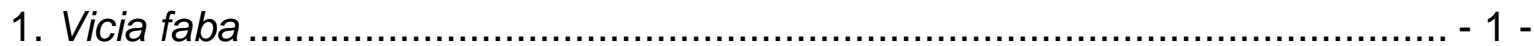

2. Winter-hardiness .................................................................................. 2 -

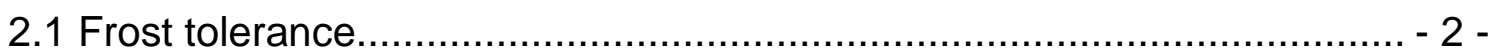

2.2 Biotic winter stress....................................................................... 4 -

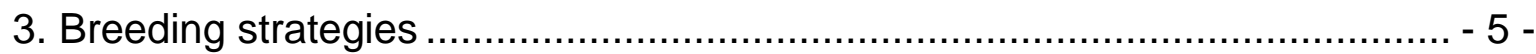

4. Molecular analyses .......................................................................... 5 -

I. Study of faba bean (Vicia faba L.) winter-hardiness and development of screening methods for frost tolerance ........................................................................ 11 -

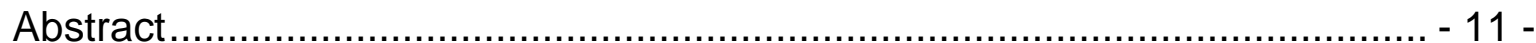

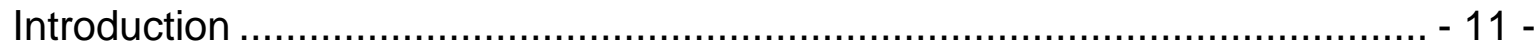

Materials and methods...................................................................... 13 -

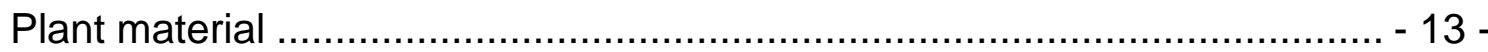

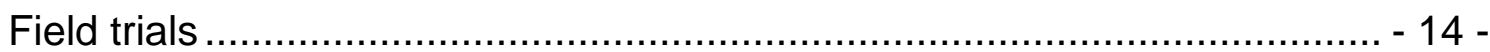

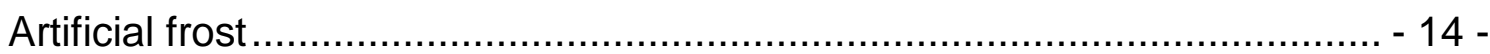

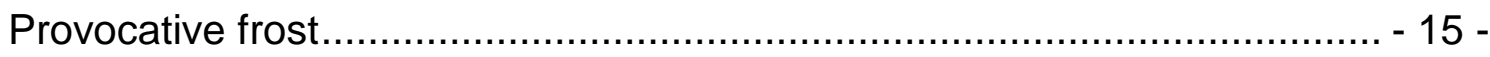

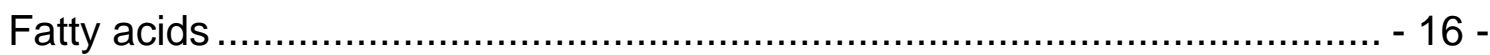

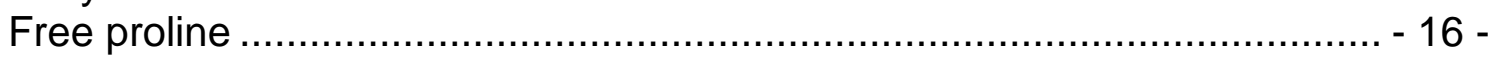

Membrane stability ........................................................................... 16 -

Statistical analyses ............................................................................. 17 -

Results and discussion ....................................................................... 17 -

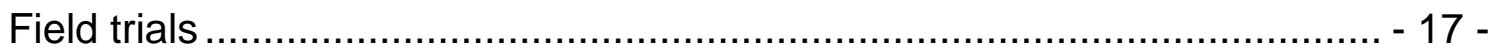

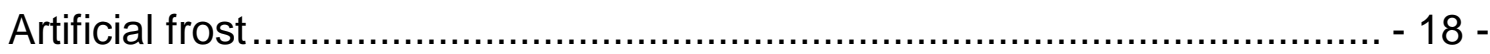

Provocative frost..................................................................................... 19 -

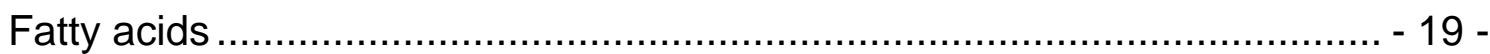

Free proline .................................................................................... 20 -

Membrane stability ......................................................................... 20 -

Correlation analyses....................................................................... 21 -

II. Effect of hardening on frost tolerance and fatty acid composition of leaves and stems of a set of faba bean (Vicia faba L.) genotypes ................................... 40 -

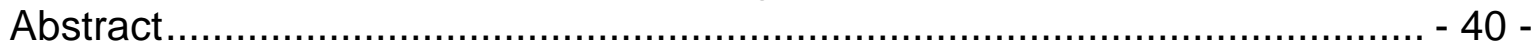

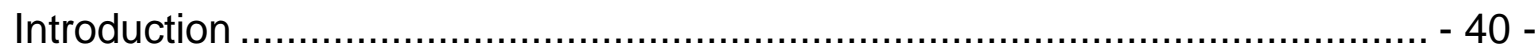

Materials and methods........................................................................ 42 -

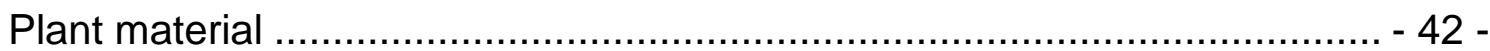

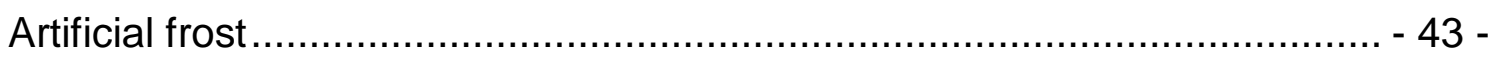

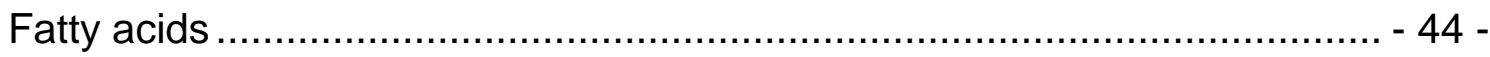

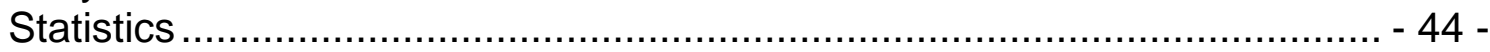

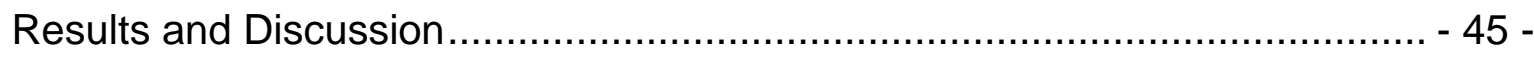

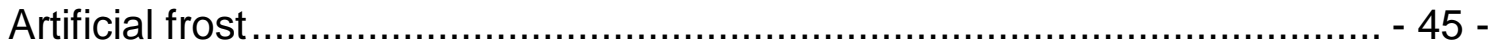

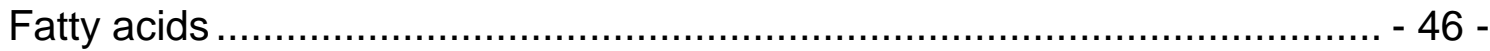

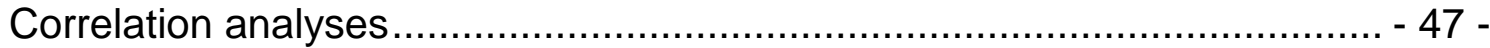

III. Quantitative trait loci of frost tolerance and physiologically related trait in faba bean (Vicia faba L.) ................................................................................. 59 -

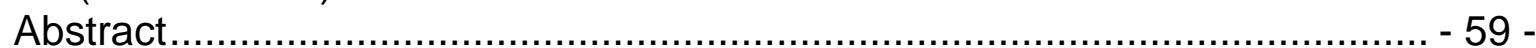

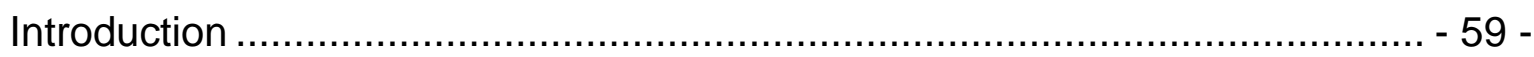

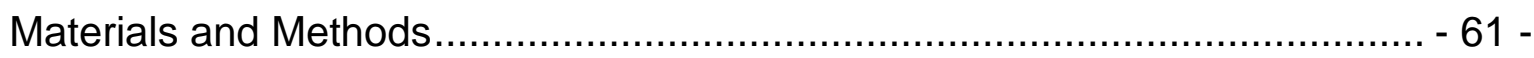

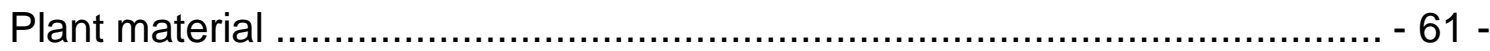

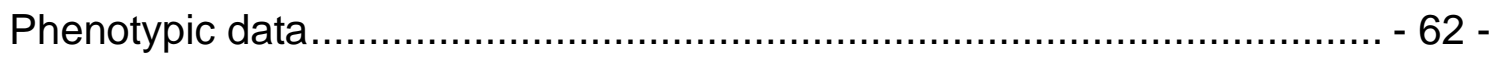




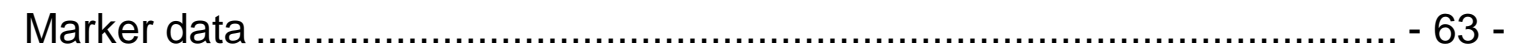

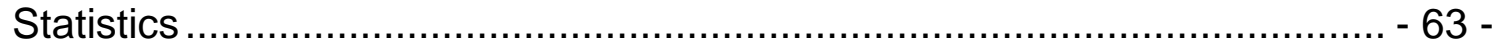

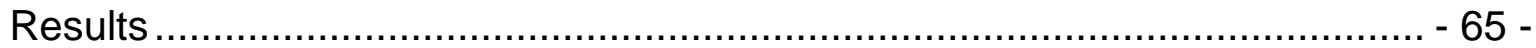

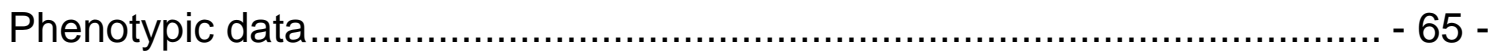

Linkage map....................................................................................... 66 -

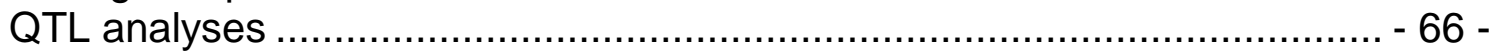

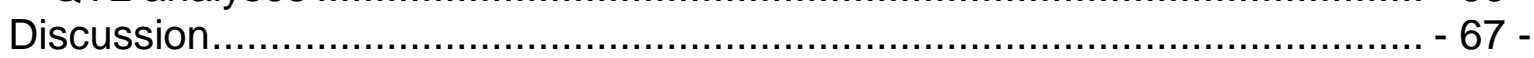

IV. Study on heterosis for frost tolerance in faba bean (Vicia faba L.) ................ - 85 -

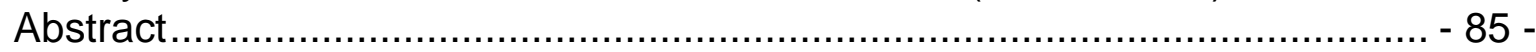

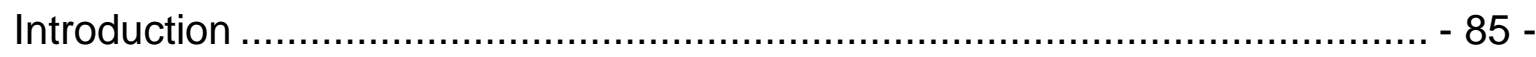

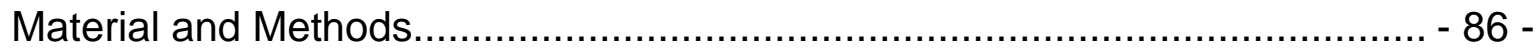

Plant Materials........................................................................................ 86 -

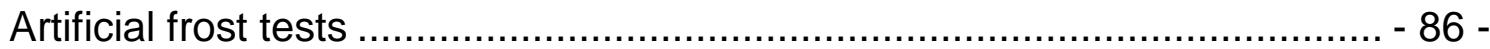

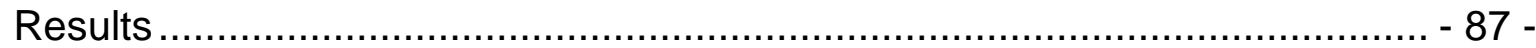

Performance and analysis of variance.............................................. 87 -

Estimates of combining abilities ..................................................... 87 -

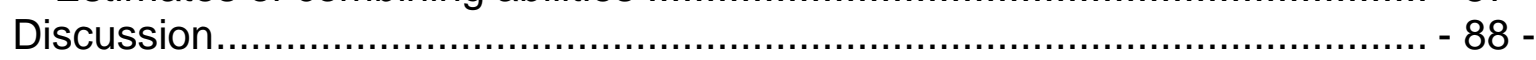

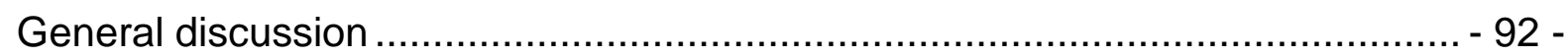

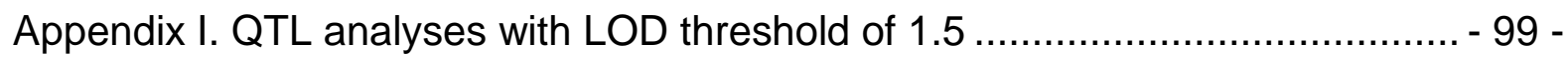

Appendix II. Marker assisted selection ................................................ - 102 -

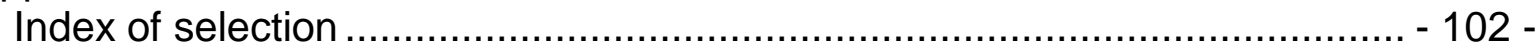

Molecular Index ............................................................................... 103 -

Phenotypic Index........................................................................... 103 -

Response to selection......................................................................... 103 -

Molecular Index ........................................................................... 103 -

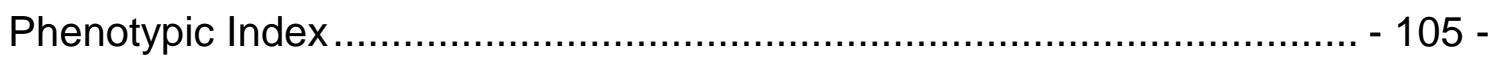

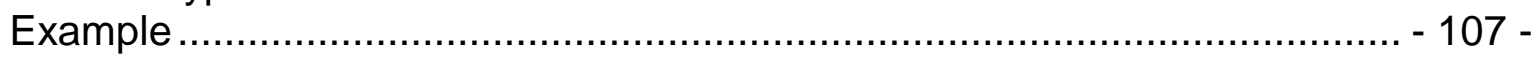

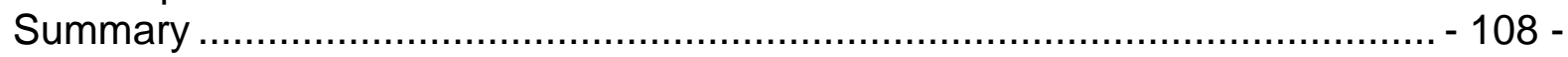

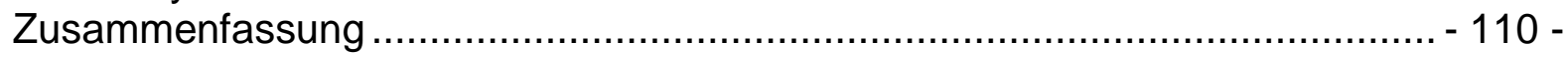

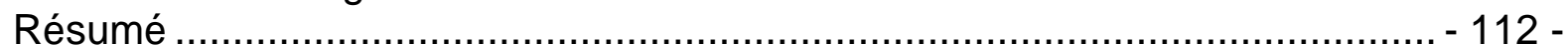

-

Acknowledgements ................................................................................ 116 - 


\section{List of tables}

\section{Chapter I}

Table 1-1. Faba bean germplasm used in experiments on frost tolerance, comprising 12 European winter cultivars and derived lines, 12 experimental lines and seven checks.

Table 1-2. Analysis of variance of grain yield $\left(\mathrm{kg} \mathrm{ha}^{-1}\right)$ of 29 faba bean genotypes in ten environments and overwintering (scoreunit) in 12 environments.

Table 1-3. Analysis of variance of frost tolerance of 31 faba bean genotypes, hardened and unhardened, assessed by artificial frost test (AUSPC-AFT, scoreunit ${ }^{\circ} \mathrm{C}$ ).

Table 1-4. Analysis of variance of frost tolerance in 31 faba bean genotypes hardened for one, two or three weeks, assessed by provocative frost tests (AUSPC-PFT, scoreunit ${ }^{\circ} \mathrm{C}$ ).

Table I-5. Mean fatty acid content in hardened and unhardened leaves (\%) of 30 faba bean genotypes.

Table I-6. Analysis of variance (F-values) of the main fatty acid contents (\%) in hardened and unhardened leaves of 30 faba bean genotypes.

Table 1-7. Analysis of variance of proline content (\%) in hardened leaves of 29 faba bean genotypes.

Table I-8. Analysis of variance of membrane stability index at four temperature steps in 28 winter faba bean genotypes.

Table 1-9. Spearman's rank correlation coefficient between mean overwintering, hardened AUSPC-AFT, AUSPC-PFT, content of C18:1 unhardened, changes in polyunsaturated fatty acids $(\mathrm{C} 18: 2+\mathrm{C} 18: 3)$, and proline content.

\section{Chapter II}

Table II-1. Faba bean germplasm used in experiments on frost tolerance, comprising 12 European winter cultivars and derived lines, 12 experimental lines and seven checks.

Table II-2. Analysis of variance of frost tolerance (AUSPC, area under symptom progress curve).

Table II-3. Mean fatty acid composition (\%) across genotypes of the first leaf, the second leaf, and the stem after hardening and without hardening.

Table II-4. Analysis of variance for fatty acid composition (\%). F-values

Table II-5. Spearman rank correlation coefficient between frost tolerance after hardening and without hardening with 18:1, 18:2, 18:3, and 18:2+18:3 fatty acid content after hardening, without hardening, and their changes due to hardening in the first leaf, the second leaf and the stem

\section{Chapter III}

Table III-1. Analysis of variance of frost tolerance (AUSPC, area under symptom progress curve).

Table III-2. Mean fatty acid composition (\%) of hardened and unhardened first leaf across genotypes and repetitions.

Table III-3. Analysis of variance for main fatty acid composition (\%). F-values and heritability. 
Table III-4. Parameters associated with putative quantitative trait loci (QTL) for frost tolerance and fatty acid composition in both treatments assessed from genotypic and phenotypic data of 101 F6 recombinant inbred lines from the cross Côte d'Or 1 x BPL 4628.

Table III-5. Relative efficiency (RE) of marker assisted selection (MAS) for frost tolerance based on pure MAS or combined MAS using phenotypic and marker data

\section{Chapter IV}

Table IV-1. Analysis of variance of combining ability for frost tolerance in $6 \mathrm{~F} 1$ and F2-hybrids of faba bean. 


\section{List of figures}

\section{Chapter I}

Figure 1-1. Temperature profile of the artificial frost test.

Figure I-2. Mean overwintering (scoreunit) and grain yield ( $\left.\mathrm{kg} \mathrm{ha}^{-1}\right)$ across all environments.

Figure 1-3. Unhardened AUSPC-AFT and hardened AUSPC-AFT (scoreunit ${ }^{\circ} \mathrm{C}$ h).

Figure I-4. Mean changes in C18:1 content and in C18:3 content due to hardening.

Figure 1-5. Frost tolerance measured by hardened artificial frost test and mean overwintering across all environments.

Figure I-6. Mean changes in polyunsaturated fatty acids due to hardening and mean overwintering across all environments.

Figure 1-7. Accumulation of free proline after hardening and mean overwintering across all environments.

Figure 1-8. Spearman's rank correlation coefficient between the membrane stability index (measured at four freezing temperatures) and four further traits: mean overwintering, AUSPC-PFT, AUSPC-AFT hardened and unhardened...... - 34 Figure 1-9. Spearman's rank correlations coefficient between overwintering in each environment with five further traits: the three related to frost tolerance, i.e., membrane stability index, free proline content, changes in polyunsaturated fatty acids, and with frost tolerance (AUSPC-AFT hardened and AUSPC-PFT). ........ 34 -

\section{Chapter II}

Figure II-1. Temperature profile of the artificial frost test.

Figure II-2. Changes in oleic acid (18:1) and linolenic acid (18:3) content due to hardening in the second leaf.

Figure II-3a. Changes in 18:2+18:3 content due to hardening and frost tolerance (area under symptom progress curve) of hardened plants. Data from the second leaf.

Figure II-3b. Changes in 18:2+18:3 content due to hardening and frost tolerance (area under symptom progress curve) of non-hardened plants. Data from the second leaf.

\section{Chapter III}

Figure III-1. Temperature profile of the artificial frost test. ............................ $75-$ Figure III-2. Correlation between hardened AUSPC and unhardened AUSPC.... - 76 Figure III-3. Correlation between changes in 18:1 and $18: 2+18: 3$ due to

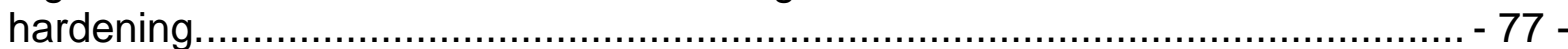

Figure III-4. Correlation between 18:1 content in unhardened leaves and unhardened AUSPC.

\section{Chapter IV}

Figure IV-1. Frost tolerance of mid-parents and their respective F1 and F2hybrids. 


\section{General discussion}

Figure GD-1. AMMI biplot of the first principal component axis and the overwintering main effect (scoreunit) of 26 genotypes and 10 environments...... 95 Figure GD-2. AMMI biplot of the first principal component axis and the grain yield main effect (scoreunit) of 26 genotypes and 9 environments. - 95 Figure GD-3. Correlation between proline (content $\mu \mathrm{mol} \mathrm{g}^{-1}$ dry matter) after hardening and hardened frost tolerance (scoreunit ${ }^{\circ} \mathrm{C} \mathrm{h}$ ) on the 87 recombinant inbred lines and the parental lines. $-96-$ Figure GD-4. Correlation between sugar content ( $\mu$ mol eq glucose $g^{-1}$ dry matter) after hardening and hardened frost tolerance (scoreunit ${ }^{\circ} \mathrm{C} h$ ) on the 87 recombinant inbred lines and the parental lines. 


\section{General introduction}

In the 21 century, the European Union is still depending to a large extent on the international supply of protein originated from vegetable kingdom. The EU is mainly importing soybean $\left(2210^{6} \mathrm{t}\right.$ by EU of 12 ; FAO, 2005) from North and South America. In order to reduce this dependency, acreage and production of protein crops like grain legumes in Europe should increase. Among others, faba bean (Vicia faba L.) has high seed protein content $(30 \%)$ and could therefore contribute to reduce the European imports of vegetable proteins. However, there are mainly two inconveniences in growing faba bean:

1. Low yield stability over years and locations, due to sensitivity to biotic (fungi, viruses, pests, parasites) and abiotic stress (drought, heat, frost).

2. Content of anti-nutritional factors (tannin in seed testa and vicine / convicine in seed). Still, recent genetic improvement enabled to develop cultivars with $0 \%$ tannin content and low vicine / convicine content.

In order to promote faba bean cropping in Europe, a multidisciplinary project funded by the European Commission was developed ("Faba bean breeding for sustainable agriculture"; acronym Eufaba) to genetically improve the crop and to make it fit to European needs.

In North and Central Europe, the major abiotic stress is freezing temperature during the winter season. Since agronomic superiority of winter types over spring types was repeatedly observed, it would be of great advantage to improve faba bean winterhardiness. Thus, the objective of the present research, as part of Eufaba, was to in detail study the genetic basis of winter-hardiness and its auxiliary traits.

Following an introductory literature review, the studied issues were arranged in four chapters, written as articles for scientific journals, and were closed by a general discussion.

The first chapter of this research aimed (1) to assess winter-hardiness of a representative sample of faba bean in extensive field trials, (2) to assess its frost tolerance as major component of winter-hardiness, (3) to quantify hardening effects on leaves for total fatty acid composition, free proline content, and membrane stability, and (4) to ultimately identify traits that prove to be involved in the genetic 
variability of winter-hardiness. Based on the same genotypic sample of frost tolerant and frost susceptible genotypes, the second chapter aimed to unravel the plant's organ responses to hardening. Thus, the objectives were (1) to test whether exposure of faba bean seedlings to hardening temperatures has a consistent effect on fatty acid saturation levels in first leaves, second leaves, and stems, (2) to assess frost tolerance of these three organs with and without hardening, and (3) to seek genetic correlations between fatty acid composition and frost tolerance for the three organs. Based on the presumable significant correlation between frost tolerance and winter-hardiness, the third chapter aimed (1) to develop a genetic linkage map on a faba bean recombinant inbred line (RIL) population, (2) to identify, map, and assess the genetic effect of QTL associated with frost tolerance and related trait, (3) to reassess the proportion of the genotypic variance explained by all putative QTL detected via re-sampling, and (4) to determine gain and relative efficiency of MAS for frost tolerance to ultimately improve winter-hardiness. In the fourth chapter, the objective was (1) to determine mid-parent heterosis for frost tolerance and (2) to suggest a strategy to make better use of heterosis in winter faba bean breeding. 


\section{Literature review}

\section{Vicia faba}

Faba bean (Vicia faba L.) is one of the earliest domesticated food legumes in the world (Schultze-Motel, 1972). Its centre of origin was localized between the oriental Mediterranean countries and Afghanistan (De Candolle, 1882; Cubero, 1974; Ladizinsky, 1975; Zohary, 1977; Abdalla, 1979). Vicia faba is a diploid species with $2 n=12$ chromosomes. From the seed size and shape and from the number of leaflets, two sub-species were identified as paucijuga and eu-faba (Muratova, 1931). The latter one was subdivided into three botanical varieties according to their seed weight: minor, equina, and major. Moreover, these three botanical varieties were also differentiated by human use: minor and equina are mainly used for animal feeding whereas major is mostly produced for human nutrition. Among the grain legume crops, faba bean has one of the highest seed protein content (30\% on average). As a legume, it is also characterized by its symbiotic fixation of atmospheric $\mathrm{N}_{2}$; it is therefore contributing to preserve the soil fertility and to reduce energy inputs during the crop cycle.

In North Africa (347000 ha; e.g. Morocco with 146000 ha) and in Asia (1098000 ha; e.g. China with $1050000 \mathrm{ha}$ ), faba bean covers large absolute and relative acreage (FAO, 2005). In Europe, faba bean is produced in limited scale (393000 ha; UK with 110000 ha). However, a renewal interest for growing this crop was observed during the past ten years (FAO). The main reasons were (1) the symbiotic $\mathrm{N}_{2}$-fixation, especially in organic farming, (2) the need of vegetable proteins in animal feeding, (3) the resistance to Aphanomyces (serious threat to peas; especially in France), and (4) the demand of the Egyptian market of faba bean for human consumption (260000 tonnes imported in 2005; FAO).

In Europe, two types of beans sown in autumn could be distinguished: Mediterranean types which are exposed to mild winters, and beans grown in North and Central European countries which are exposed to harsh winters (Bond et al., 1994; Stoddard et al., 2006). In these cool-temperate countries, faba bean is mainly grown as spring crop because of the insufficient winter-hardiness of the current autumn-sown genotypes. 


\section{Winter-hardiness}

The actual winter-hardiness of a genotype depends mainly on (1) its frost tolerance, (2) its resistance against biotic stress such as snow mould, and (3) its tolerance to adverse abiotic conditions like level of saturation of soil with water. Field based winter-hardiness of a genotype is expressed by measuring its overwintering. For this purpose, number of surviving plants is assessed.

The importance of studying and improving this trait came from its significant correlation with grain yield for most winter crops (e.g. Rizza et al., 1994), and from the superiority of winter beans over spring beans for protein and grain yield (e.g. Ghaouti and Link, 2007). However, limited data and achievements were reported on this area in faba bean.

\subsection{Frost tolerance}

Frost tolerance of a plant depends on its unhardened frost tolerance and on its hardening response. Both traits were found to be inherited separately (Stone et al., 1993). Frost tolerance was found to be a main component of winter-hardiness in cereals and in legumes (Auld et al., 1983; Rizza et al, 1994; Petcu and Terbea 1995), showing up freezing temperatures as major winter stress. In faba bean, based on a diallel cross experiment, Duc and PetitJean (1995) found as well significant relationship between these two traits.

In most cases, frost tolerance was determined by experiments under controlled conditions. These experiments were mainly based on visual scoring of freezing injuries in leaves (Herzog, 1989; Duc and PetitJean, 1995; Badaruddin and Meyer, 2001), measuring of regrowth or of leaf conductivity (Herzog, 1987), and evaluating chlorophyll fluorescence (Taulavuori et al., 2000; Hoffmann-Bahnsen and Herzog, 2001). Visual scoring of freezing injuries was shown to be at least as reliable as conductivity and chlorophyll fluorescence measurements (Herzog, 1987).

In most studies, frost tolerance was expressed as the lethal temperature at which $50 \%$ of the plants are killed (LT50; Herzog, 1987; Herzog, 1989; Dörffling et al., 1997). In faba bean, LT50 of unhardened plants was found to be on average $-4.8^{\circ} \mathrm{C}$ and $-12^{\circ} \mathrm{C}$ for hardened plants (Herzog, 1987). Moreo ver, Von Fircks and Verwijst (1993) proposed to assess plant response to freezing temperatures over the entire range between LTO (defined as the lowest temperature to which plants can be 
exposed without showing visual damage) and LT100 (corresponding to the temperature to which no plants are surviving).

Hardening, also known as cold acclimation is the result of an exposure to low nonfreezing temperatures (Levitt, 1980). In natural conditions, hardening occurs seasonally when seedlings are exposed to these temperatures before the onset of winter. Hardening conditions, like its duration, influence the frost tolerance ultimately reached. In most studies, the hardening temperatures were set between $0^{\circ} \mathrm{C}$ and $10^{\circ} \mathrm{C}$. Herzog (1989) showed that faba bean seedlings should be kept at least 10 days at low non-freezing temperatures to reach their maximum level of frost tolerance.

As adaptation mechanisms to exposure to low non-freezing temperatures, physiological and biochemical changes were observed on plant tissues. The main changes were:

1. Accumulation of simple sugars. After hardening, the de-polymerisation of fructan (fructose polymers) is an important source of cryoprotection for the plant (Olien and Clark, 1993; Livingston, 1996). Its accumulation in plant tissues was observed to be significantly correlated with frost tolerance (Pollock, 1986; Santoiani et al., 1993). Moreover, the hydrolysis of fructan under hardening induced accumulation of mono and disaccharides. Accumulation of these soluble sugars was found to be as well correlated with frost tolerance (Livingston, 1996); especially the saccharose (Steponkus and Lanphear, 1968; Levitt, 1980).

2. Increase of total protein concentration after hardening (Davis and Gilbert; 1970; McKenzie et al., 1988). These proteins could be involved in fatty acid desaturation and in morphological and developmental changes. Increase of protein content was shown to induce e.g. dormancy (Muthalif and Rowland, 1994; Arora et al., 1997); the dormancy defined as temporary state of lowered metabolism and arrested growth.

3. Accumulation of free proline. When plants are exposed to any abiotic stress (drought, high temperatures, freezing temperatures), an accumulation of amino acids and especially of proline is observed in cells. It seems to play an important cryoprotective role by preserving the cellular structures from dehydratation, induced by e.g. freezing temperatures (Delauney and Verma, 1993; Galiba, 1994). Significant correlations were found between proline accumulation and frost tolerance (Petcu and Terbea, 1995; Dörffling et al., 1997; Thomashow, 1999). 
4. Increase of the cell membrane stability in the following frost stress period (Chandrasekar et al., 2000).

5. Increase of total lipids and polyunsaturated fatty acid content (linoleic and linolenic acids). The accumulation of these polyunsaturated fatty acids is the result of desaturase enzyme activity, mainly on oleic acid (Wei et al., 2005). During hardening, an over-expression of these enzymes was observed in leaf tissues (Wei et al., 2005). Moreover, the changes occurring in linolenic acid content in leaves were found to be significantly correlated to frost tolerance (Cyril et al., 2002). All these changes were shown to protect the cell membranes and to prevent cell dehydration from an extracellular ice formation. In young growing leaves of tobacco and Arabidopsis, polar lipids represent more than $75 \%$ of the total lipid content in cells (Koiwai et al., 1981; Kaup et al., 2002). Thus, at least $75 \%$ of the fatty acids that could be extracted from the total lipids contained in leaves of such dicotyledonous plants are expected to be located in cell membranes.

In most studies undertaken on these physiological responses to hardening, few genotypes were tested (up to five). Such limited material size prevented often to draw conclusions on their significant relationship with the agronomic trait.

\subsection{Biotic winter stress}

Under a snow cover, the temperature in the soil is in most cases higher than $0^{\circ} \mathrm{C}$ (McBeath, 2002; Decker et al., 2003). These hardening temperatures keep the plants in dormancy stage and do not prevent the development of pathogenous fungi (e.g. snow mould). Most snow mould pathogens cause plant injury only under prolonged snow cover. Snow mould diseases are severe primarily in regions where snow cover persists for more than 100 days (Gossen et al., 2001). The snow mould encompasses Ascomycota, Basidiomycota, and Oomycota fungus classes. Several approaches to control snow mould have been investigated, including the use of resistant cultivars, snow removal, modified management practices, fungicides, and biological control.

Since faba bean is apparently sensitive to some of these fungus genus (e.g. Sclerotinia, Fusarium), the resistance of genotypes to snow mould would likely influence their winter-hardiness. However, very few is known on faba bean resistance against these winter pathogens. 


\section{Breeding strategies}

Faba bean breeding programs are markedely shaped by the cross fertilization rate of faba bean (50\% on average; Link, 1990). Thus, the existing cultivars are mainly synthetics or populations. In comparison to spring cultivars, there are few winter cultivars released. Most of them originated from France (e.g. landrace Côte d'Or, and cultivars Karl, Diva, Bourdon), UK (Bulldog, Clipper, Target; bred by Bond and Pope), and Germany (Winter Bean Population of Göttingen; Hiverna, Wibo, bred by Littman, 1979).

A study on heterosis for frost tolerance revealed relatively large general combining ability effects (GCA) and a marked superiority of F1 over mean parental lines (Duc and PetitJean, 1995). This result suggested that the genetic variation of frost tolerance resulted to a large extent from additive effects and to a lower extent from dominance effects. Still, due the instability of the available cytoplasmic male sterility systems (CMS; Martsch, 2001), synthetic varieties seem to be the best way to make use of heterosis.

However, improving winter-hardiness is actually a difficult task, mainly due to the irregular occurrence of natural freezing temperatures that would allow appropriate differentiation among genotypes, and especially due to the complexity of the trait itself. For higher selection efficiency, the use of auxiliary traits (frost tolerance and physiological traits) or of molecular markers could be very useful.

\section{Molecular analyses}

During the past 15 years, genetic linkage maps were developed to locate DNA markers linked to quantitative trait loci (QTL) involved in the inheritance of important agronomic traits. Such putative QTL explain significant proportions of the phenotypic variance of a trait. Under the assumption of equal heritability for all detected QTL, the genotypic variance of the trait explained by these QTL was also assessed.

Based on this proportion and the trait's heritability, the relative efficiency of marker assisted selection (MAS) over classical phenotypic selection (CPS) was assessed (Lande and Thompson, 1990). Whereas MAS was successfully applied in some breeding programs (Yousef and Juvik, 2001), it also failed in other programs mainly because of the overestimation of the genotypic variance explained. 
Such an overestimation is due to several factors: restricted size of mapping population, limited genome coverage, and low congruency of the putative QTL detected over generations and populations. In order to determine the unbiased genotypic proportion explained by QTL, several methods based on re-sampling were proposed: bootstrapping, cross-validation and independent sample test. The use of independent sample test provides the most unbiased estimate but with the highest costs. On the other hand, cross-validation enables to reduce more efficiently the bias than the bootstrapping (Utz et al., 2000).

In faba bean breeding research, genetic linkage maps were developed to identify QTL for seed quality and resistance to biotic stress (Román et al., 2002; Román et al., 2003), yet none for tolerance to abiotic stress.

\section{References}

Abdalla, M.M.F. 1979. The origin and evolution of Vicia faba L. Proc. First Meditteranean conf. pp. 714-746.

Arora, R., L.J. Rowland, and G.R. Panta. 1997. Chill-responsive dehydrins in blueberry: are they associated with cold hardiness or dormancy transition? Physiol. Plant. 101:8-16.

Auld, D.L., R.L. Ditterline, G.A. Murray, and J.B. Swensen. 1983. Screening peas for winter-hardiness under field and laboratory conditions. Crop Sci. 23:85-88.

Badaruddin,M., and D.W. Meyer. 2001. Factors modifying frost tolerance of legume species. Crop Sci. 41:1911-1916.

Bond, D.A., G.J. Jellis, G.G. Rowland, J. Le Guen, L.D. Robertson, S.A. Khalil, and L. Li-Juan. 1994. Present status and future strategy in breeding faba beans (Vicia faba L.) for resistance to biotic and abiotic stresses. Euphytica. 73:151-166.

Chandrasekar, V., R.K. Sairam, and G.C. Srivastava. 2000. Physiological and biochemical responses of hexaploid and tetraploid wheat to drought stress. J. Agron. Crop Sci. 185:219-227.

Cubero, J.I. 1974. On the evolution of Vicia faba, Theor. Appl. Genet. 45:47-51. In: Genetic Resources and their Exploitation-Chickpeas, Beans and Lentils. J.R. Witcombe, and W. Erskine (eds.). 
Cyril, J., G.L. Powell, R.R. Duncan, and W.V. Baird. 2002. Changes in membrane polar lipid fatty acids of Seashore Paspalum in response to low temperature exposure. Crop Sci. 42:2031-2037.

Davis, D.L., and W.B. Gilbert. 1970. Winter hardiness and changes in soluble protein fractions of bermudgrass. Crop Sci. 10:7-9.

De Candolle, A. 1882. Origin of Cultivated Plants, Second eds. Reprint 1967, pp 468. Hafner, New York.

Decker, K.L.M., D. Wanga, C. Waitea, and T. Scherbatskoya. 2003. Snow removal and ambient air temperature effects on forest soil temperatures in Northern Vermont. Soil Sci. Soc. America J. 67:1234-1242.

Delauney, A.J., and D.P.S. Verma. 1993. Proline biosynthesis and osmoregulation in plants. Plant J. 4:215-223.

Dörffling, K., H. Dörffling, G. Lesselich, E. Luck, C. Zimmermann, G. Melz, and H.U. Jürgens. 1997. Heritable improvement of frost tolerance in winter wheat by in vitro-selection of hydroxyproline-resistant proline overproducing mutants. Euphytica. 93:1-10.

Duc, G., and F. PetitJean. 1995. Study of inheritance of freezing tolerance in Vicia faba L. 2nd European Conference on Grain Legumes. Copenhagen. Denmark. 11-15 July 1995 .

FAO (Food and Agriculture Organization), 2006. http://faostat.fao.org

Galiba, G. 1994. In vitro adaptation for drought and cold hardiness in wheat. Plant Breeding Reviews. 12:115-162.

Ghaouti, L. 2007. Comparison of pure line cultivars with synthetic cultivars in local breeding of faba bean (Vicia faba L.) for organic farming. PhD thesis, University of Göttingen.

Gossen, B.D., T. Hsiang, and T.D. Murray. 2001. Managing Snow Mold Diseases of Winter Cereals and Turf. In: Low Temperature Plant Microbe Interactions Under Snow. N. Iriki, D.A. Gaudet, A.M. Tronsmo, N. Matsumoto, M. Yoshida and A. Nishimune (eds.), Hokkaido National Agricultural Experiment Station.

Herzog, H. 1987. A quantitative method to assess freezing resistance in faba beans. J. Agron. Crop Sci. 158:195-204. 
Herzog, H. 1989. Influence of pre-hardening duration and dehardening temperatures on varietal freezing resistance in faba beans (Vicia faba L.). Agronomie (Paris). 9:55-61.

Hoffmann-Bahnsen, R., and H. Herzog. 2001. Frost resistance-screening in Lupinus albus based on chlorophyll fluorescence measurements: a methodical evaluation and adjustment. 4th European Conference on Grain Legumes. Cracow. Poland. 8-12 July 2001.

Kaup, M.T., C.D. Froese, and J.E. Thompson. 2002. A role for diacylglycerol acyltransferase during leaf senescence. Plant Physiol. 129:1616-1626.

Koiwai, A., T. Matsuzaki, F. Suzuki, and N. Kawashima. 1981. Changes in total and polar lipids and their fatty acid composition in tobacco leaves during growth and senescence. Plant Cell Physiol. 22:1059-1065.

Ladizinsky, G. 1975. On the origin of the broad bean, Vicia faba L. Israel J. Bot. 24:80-88.

Lande, R., and R. Thompson. 1990. Efficiency of marker assisted selection in the improvement of quantitative traits. Genetics. 124:743-756.

Levitt, J. 1980. Responses of Plants to Environmental Stresses. Vol. 1. Academic Press, New York. 166-222.

Link, W. 1990. Autofertility and rate of cross-fertilization: Crucial characters for breeding synthetic varieties in faba beans (Vicia faba L.). Theor. Appl. Genet. 79:713-717.

Littman, H. 1979. Winterbohnen. Veröffentlichung des Rationalisierungs-Kuratoriums für Landwirtschaft. August 1979:167-170.

Livigston, D.P. 1996. The second phases of cold hardening: freezing tolerance and fructan isomer changes in winter cereal crowns. Crop Sci. 36:1568-1573.

Martsch, R., J. Vaupel, C.C. Schön, and W. Link. 2001. Faba bean hybrid breeding: Current results with CMS199. pp 232-233. In: Fourth Conf. on Grain Legumes, AEP (ed.) Cracow, Poland.

McBeath, J.H. 2002. Snow mold-plant-antagonist interactions: survival of the fittest under the snow. The Plant Health Instructor. DOI: 10.1094/PHI-I-2002-1010-01. 
McKenzie, J.S., R. Paquin, and S.H. Duke. 1988. Cold and Heat Tolerance. In: Alfalfa and Alfalfa Improvement. A.A. Hanson, D.K. Barnes, and R.R. Hill, Jr (eds.). Agronomy Monograph No. 29, ASA, WI, pp. 259-302.

Muratova, V. 1931. Common Beans (Vicia faba). Bulletin of Applied Botany, Genetics and Plant Breeding. Supplement 50. In: Genetic Ressources And Their Exploitation-Chickpeas, Beans and Lentils. J.R. Witcombe, and W. Erskine (eds.).

Muthalif, M.M., and L.J. Rowland. 1994. Identification of chilling responsive proteins from floral buds of blueberry. Plant Sci. 101:41-49.

Olien, C.R., and J.L. Clark. 1993. Changes in soluble carbohydrates of rye. Crop Sci. 25:288-290.

Petcu, E., and M. Terbea. 1995. Proline content and the conductivity test as screening methods for frost tolerance of winter wheat. Bulg. J. Plant Physiol. 21:3-11.

Pollock, C.J. 1986. Fructans and the metabolism of sucrose in vascular plants. New Phytol. 104:1-24.

Rizza, F., C. Crosatti, A.M. Stanca, and L. Cativelli. 1994. Studies for assessing the influence of hardening on cold tolerance of barley genotypes. Euphytica. 75:131-138.

Román B., A.M. Torres, D. Rubiales, J.I. Cubero, and Z. Satovic. 2002. Mapping of quantitative trait loci controlling broomrape (Orobanche crenata Forsk.) resistance in faba bean (Vicia faba L.). Genome. 45:1057-1063.

Román B., Z. Satovic, C.M. Avila, D. Rubiales, M.T. Moreno, and A.M. Torres. 2003. Locating genes associated with Aschochyta fabae resistance in Vicia faba. Aust. J. Agric. Res. 54:85-90.

Santoiani, C.S., J.A. Tognetti, H.G. Pontis, and G.L. Salerno. 1993. Sucrose and fructan metabolism in wheat roots at chilling temperature. Physiol. Plant. 87:8488.

Schultze-Motel, J. 1972. Die Archäologischen Reste der Ackerbohne Vicia faba L., und die Genese der Art. Kulturpflanze. 19:321-358. In: Genetic Ressources and 
their Exploitation-Chickpeas, Beans and Lentils, J.R. Witcombe, and W. Erskine (eds.).

Steponkus, P.L., and F.O. Lamphear. 1968. The relationship of carbohydrate to cold acclimation of Hedera helix L. cv. Thorndale. Physiol. Plant. 20:777-791.

Stoddard, F.L., C. Balko, W. Erskine, H.R. Khan, W. Link, and A. Sarker. 2006. Screening techniques and sources of resistance to abiotic stresses in coolseason food legumes. Euphytica. 147:167-186.

Taulavuori, K., E. Taulavuori, T. Sarjala, E.M. Savonen, P. Pietiläinen, P. Lähdesmäki, and K. Laine. 2000. In vivo chlorophyll fluorescence is not always a good indicator of cold hardiness. J. Plant Physiol. 157:227-229.

Thomashow, M.F. 1999. Plant cold acclimation: freezing tolerance genes and regulatory mechanisms. Annu. Rev. Plant Physiol. Plant Mol. 50:571-599.

Utz, H.F., A.E. Melchinger, and C.C. Schön. 2000. Bias and sampling error of the estimated proportion of genotypic variance explained by quantitative trait loci determined from experimental data in maize using cross validation and validation with independent samples. Genetics. 154:1839-1849.

Von Fircks, H.A., and T. Verwijst. 1993. Plant viability as a function of temperature stress. Plant Physiol. 103:125-130.

Wei, H., A.L. Dhanaraj, R. Arora, L.J. Rowland, Y. Fu, and L. Sun. 2005. Identification of cold acclimation-responsive Rhododendron genes for lipid metabolism, membrane transport and lignin biosynthesis: importance of moderately abundant ESTs in genomic studies. Plant Cell Environ. 29:558-570.

Yousef, G.G., and J.A. Juvik. 2001. Comparison of phenotypic and marker-assisted selection for quantitative traits in sweet corn. Crop Sci. 136:1457-1468.

Zohary, D. 1977. Comment on the origin of cultivated Broad bean (Vicia faba L.), Israel J. Bot. 26:39-40. 


\section{Study of faba bean (Vicia faba L.) winter-hardiness and development of screening methods for frost tolerance}

M. Arbaoui, C. Balko, and W. Link (prepared for Crop Science)

\section{Abstract}

In cool-temperate regions, faba bean (Vicia faba L.) is mainly grown as a spring crop despite the higher yield potential of the winter type, because of the insufficient winterhardiness of the present winter genotypes. The objective of this study was to assess winter-hardiness and frost tolerance, to quantify the hardening effect on physiological traits, and to identify auxiliary traits for winter-hardiness. To do so, 31 representative entries were tested in 12 European environments for winter-hardiness, and in artificial and provocative frost tests for frost tolerance. In addition, total fatty acid composition, proline content, and membrane stability of leaves were analysed. Across all environments, five European winter genotypes were identified with superior winterhardiness. Artificial and provocative frost tests indicated that frost tolerance is a significant, but not an exhaustive component of winter-hardiness $(0.021<|r|<$ $\left.0.737^{\star \star}\right)$. These tests revealed the high frost tolerance of several poorly winter-hardy experimental lines and the limited frost tolerance of well known winter types. Fatty acid changes due to hardening, proline content, and membrane stability index were more strongly correlated with frost tolerance than with field based winter-hardiness. Although frost tolerance, fatty acid composition, proline content, and membrane stability were significantly correlated with winter-hardiness, the rather low correlation values do not allow a general use of one of them alone to indirectly select for general winter-hardiness. Nevertheless, in environments with intermediate winter strength, artificial and provocative frost tests could be used to indirectly screen for winterhardiness.

\section{Introduction}

Winter-hardiness depends partly on the ability of plants to survive the freezing temperatures during winter. Since winter-hardiness strongly influences grain yield, improving it is of importance for many winter crops. In the case of faba bean (Vicia faba L.), there are two types sown in autumn: Mediterranean types that are exposed to mild winters, and beans grown in cool-temperate regions with harsh winters (Bond et al., 1994; Stoddard et al., 2006). In cool-temperate climates, faba bean is widely 
grown as a spring crop because of the insufficient winter-hardiness of the current autumn-sown germplasm. Recent studies have shown the superiority of protein and grain yield in winter beans, as compared to spring beans. Therefore, improving winter-hardiness is important for promoting faba bean cropping in these climates.

Improving winter-hardiness is a difficult task, on account of the irregular occurrence of appropriate natural freezing temperatures that allow differentiation among genotypes, and also the complexity of the trait itself. The winter-hardiness of a plant depends mainly on (1) its frost tolerance, (2) its resistance against biotic stress such as snow mould, and (3) its tolerance to adverse abiotic conditions such as levels of saturation of soils with water (Davidson and Reid, 1987; Herzog, 1987a; Badaruddin and Meyer, 2001).

The frost tolerance of a plant depends mainly on its unhardened frost tolerance and on its hardening response. Both traits were found to be inherited independently (Stone et al., 1993). Hardening, also known as cold acclimation, is the result of exposure to low non-freezing temperatures (Levitt, 1980). Many studies have proven that hardening improves frost tolerance of seedlings (Herzog, 1987b; Rizza et al., 1994; Petcu and Terbea, 1995; Badaruddin and Meyer, 2001) up to a maximum level (Herzog, 1989).

In order to avoid unpredictable environmental conditions, experiments under controlled conditions were developed to analyse frost tolerance. These experiments were mainly based on the following methods: visual scoring of freezing injuries in leaves (Herzog, 1987b; Herzog, 1989; Rizza et al., 1994; Duc and PetitJean, 1995; Badaruddin and Meyer, 2001), measuring of regrowth or of leaf conductivity (Herzog, 1987b), and evaluating chlorophyll fluorescence (Herzog and Olszewski, 1998; Taulavuori et al., 2000; Hoffmann-Bahnsen and Herzog, 2001). Although visual scoring of freezing injuries may not be perfectly impartial, it was as reliable as conductivity and chlorophyll fluorescence measurements (Herzog, 1987b; Herzog and Olszewski, 1998). These methods have been mainly applied to leaves for four major reasons: (1) they are directly exposed to freezing temperatures and low nonfreezing temperatures, (2) their freezing injury causes strong retardation of the crop development, (3), higher accumulation of mRNA, coding for specific proteins contributing to frost tolerance, was measured in the leaves than in stems and roots 
during hardening (Ohno et al., 2001), and (4) leaf measurements are non-destructive for the plants, an important aspect for application in breeding.

Hardening has been shown to induce several physiological and biochemical changes, including (1) accumulation of sucrose and fructans (Pollock, 1986; Santoiani et al., 1993), (2) increase of total protein concentration (Davis and Gilbert; 1970; McKenzie et al., 1988), (3) accumulation of free proline (Petcu and Terbea, 1995; Dörffling et al., 1997; Thomashow, 1999), (4) increase of cell membrane stability in the following frost-stress period (Chandrasekar et al., 2000), (5) increase of total lipids and their polyunsaturated fatty acid content (linoleic and linolenic acids), and (6) increase of fatty acid desaturase enzyme activity (Cyril et al., 2002; Wei et al., 2005). All these changes were shown to protect the cell membranes and to prevent cell dehydration from extracellular ice formation. In young growing leaves of tobacco and Arabidopsis, more than $75 \%$ of the total lipid content was polar (Koiwai et al., 1981; Kaup et al., 2002) and thus presumably located in cell membranes.

Since frost tolerance depends partly on hardening, all these biochemical changes may influence its expression. Therefore, understanding them would offer additional tools to improve breeding programs for frost tolerance.

The objective of the present study was (1) to assess winter-hardiness of a representative sample of faba bean in extensive field trials, (2) to assess its frost tolerance as major component of winter-hardiness, (3) to quantify hardening effects on leaves for total fatty acid composition, free proline content, and membrane stability, and (4) to ultimately identify traits that prove to be involved in the genetic variability of winter-hardiness.

\section{Materials and methods}

Plant material

A representative set of frost-tolerant faba bean germplasm was used as material: 12 European winter genotypes, 12 experimental lines, and seven checks (including three spring genotypes; Table 1). The European genotypes were selected due to their current importance in breeding, their reasonable winter-hardiness and good yield performance. The experimental lines resulted from crosses between BPL 4628 ("Bean Pure Line", Chinese inbred line from the ICARDA germplasm collection), Scirocco (Sci, German spring inbred line) and Côte d'Or/1 (inbred line derived from 
the winter-hardy French landrace Côte d'Or). Five traits were measured on these entries: winter-hardiness in field trials, frost tolerance in so-called artificial frost tests and in provocative frost tests, total fatty acid composition of leaves, free proline content and membrane stability of leaves. For frost tolerance and fatty acid composition, during germination and emergence, the temperature was kept at $10^{\circ} \mathrm{C}$ days $/ 3^{\circ} \mathrm{C}$ nights for 14 days to produce hardened seedlings, and at $18^{\circ} \mathrm{C}$ days / $15^{\circ} \mathrm{C}$ nights for 10 days to produce unhardened seedl ings. For every genotype, four seedlings were grown in a pot $\left(17 \times 17 \times 17 \mathrm{~cm}^{3}\right)$ filled with $5 \mathrm{~kg}$ of soil (1:1 mixture of sand and compost). The soil was kept between $70 \%$ and $80 \%$ of its saturation level.

Field trials

All genotypes were evaluated in the field during four years at five European locations: Göttingen (Gött; 2004-2006) and Hohenlieth (Hoh; 2003-2005) in Germany, Šumperk in Czech Republic (Sum; 2004, 2005), Gleisdorf in Austria (Gld; 2003-2005), and Jõgeva in Estonia (Jog; 2005), i.e., altogether at $\mathrm{N}=12$ environments, one environment being one location in one year. The genotypes were randomized in two replicates $(\mathrm{N}=11)$ or one $(\mathrm{N}=1)$ per environment. Plots of $4.5 \mathrm{~m}^{2}$ with four rows were sown, with a sowing density of 22 seeds $\mathrm{m}^{-2}$. To describe environments, winter strength was assessed by counting the number of days with temperatures lower than $-6^{\circ} \mathrm{C}$. At the end of winter, overwintering was score $d$ on a linear 1-9 scale (1: no survivals; 9: all plants survived), and was considered as the expression of the winterhardiness (Auld et al., 1983; Rizza et al., 1994). Lodging, disease infestation, and grain yield were also recorded during the season.

\section{Artificial frost}

In order to assess frost tolerance, the first method was based on experiments in a plant growth chamber $\left(2 \times 2 \times 2 \mathrm{~m}^{3}\right)$, which can produce freezing temperatures. When the seedlings reached two expanded leaves, all pots were transferred (i.e., loaded) to the frost chamber. One such transfer was called a load. Hardened seedlings were exposed to temperature of $2.5^{\circ} \mathrm{C}$ days $/ 0^{\circ} \mathrm{C}$ nights $\mathrm{d}$ uring one week before starting the test. Chamber lighting was programmed at $200 \mu \mathrm{mol} \mathrm{s} \mathrm{m}^{-2}$ for 12 hours, and air humidity freely fluctuated between approximately $80 \%$ and $90 \%$ according to temperature. 
The test included six steps of decreasing freezing air temperatures during "night" and thawing during the artificial "day" (Fig. 1). After each step, and after ten hours of thawing, three organs for every seedling, i.e., first leaf, second leaf, and stem were visually scored (Herzog 1987b; Duc and PetitJean, 1995) for colour (1 = green, $4=$ black) and for turgidity ( $1=$ fully turgid, $4=$ not turgid). Thus, six traits were scored: first leaf colour (FLC), second leaf colour (SLC), stem colour (StC), first leaf turgidity (FLT), second leaf turgidity (SLT), and stem turgidity (StT). For each trait, scores resulting from every step were combined. The product of actual freezing temperature $\left({ }^{\circ} \mathrm{C}\right)$ and duration of freezing temperature under $-6^{\circ} \mathrm{C}$ (hours) was calculated to determine the number of degree-hours $\left({ }^{\circ} \mathrm{C} h\right.$ ). Finall y, the score at each freezing step was multiplied with its corresponding number of degrees hours and added across the six steps to produce the "Area Under Symptom Progress Curve" in artificial frost tests (AUSPC-AFT; corresponding to the "Area Under Disease Progress Curve", AUDPC; Shaner and Finney, 1977; Bouhassan et al., 2004). Thus, the lower the result of the AUSPC-AFT was, the higher was the frost tolerance. In both treatments, genotypes were randomised in three loads, with three replicates per load; one replicate value being the pot average for AUSPC across the six traits and across the four seedlings of the pot.

\section{Provocative frost}

The second method was conducted as an outdoor experiment, and only hardened seedlings were tested. The experiments were performed in January 2006 at Göttingen. The 31 genotypes were randomly distributed and tested in three treatments, with two replicates per treatment. The treatment was length of hardening. Seedlings were hardened by exposure to appropriate natural low non-freezing temperatures $\left(0^{\circ} \mathrm{C}\right.$ to $\left.5^{\circ} \mathrm{C}\right)$ for one, two or three wee ks. Afterwards, they were tested by exposure to natural freezing temperatures for 72 hours; this being one of three steps. After each step, seedlings were transferred to a greenhouse for thawing for 12 hours at $5^{\circ} \mathrm{C}$. After ten hours of thawing, the same six traits as in the artificial frost test were scored for every seedling. Similarly, the "Area Under Symptom Progress Curve" in provocative frost tests was calculated (AUSPC-PFT). At the first, the second, and the third step the minimum natural air temperatures recorded at the leaves were $-11^{\circ} \mathrm{C},-16{ }^{\circ} \mathrm{C}$, and $-17^{\circ} \mathrm{C}$, respectively. 
For both methods, mean AUSPC was considered as the expression of the frost tolerance.

Fatty acids

First leaves and second leaves of hardened and unhardened seedlings were analyzed for fatty acid composition. In both treatments, 30 of the 31 entries were tested in three experiments with two replicates. Only two out of four seedlings per pot were used as one replicate. When there were two fully expanded leaves, shoots were cut, dried at $50^{\circ} \mathrm{C}$ for 48 hours, and ground to a fine powder. Total tissue lipid extraction followed the experimental protocol of Thies (1971). The total fatty acid composition was analyzed by gas chromatography (model 8600, PerkinElmer Inc., Waltham, MA, USA). Three-microliter samples were manually injected into the column (Permabond FFAP-0.25 $\mu \mathrm{m}, 25 \mathrm{~m} \times 0.25 \mathrm{~mm}$ ). The column temperature was $215^{\circ} \mathrm{C}$, injector temperature $280^{\circ} \mathrm{C}$ and detector temp erature $280^{\circ} \mathrm{C}$. The carrier gas was hydrogen at a pressure of $100 \mathrm{kPa}$. The individual peaks were identified based on comparisons to a standard sample. The quantity of each fatty acid was expressed as relative percentage of the total fatty acid content.

\section{Free proline}

Accumulation of free proline in hardened leaves was determined for 29 of the 31 genotypes. Seeds of each genotype were imbibed in water for two days at $21^{\circ} \mathrm{C}$ then sown in vermiculite in $10 \times 10 \times 10 \mathrm{~cm}^{3}$ pots. During germination and emergence, the temperature and the photoperiod were programmed at $21^{\circ} \mathrm{C}$ days $/ 18{ }^{\circ} \mathrm{C}$ nights and 16 hours, respectively. Daily, seedlings were watered with Hoagland solution. After two weeks, seedlings were transferred to a plant growth chamber for hardening, and were kept at $4^{\circ} \mathrm{C}$ days $/ 2^{\circ} \mathrm{C}$ nights for three weeks. At the three- to four-leaf stage, leaf discs (youngest fully grown leaf) were taken and freeze-dried, dry weight was measured, and free proline content was determined photometrically according to Troll and Lindsley (1955) as modified by Bates et al. (1973). For every genotype, there were four replicates containing five leaf discs from different plants.

Membrane stability

Growing conditions for producing hardened seedlings were the same as used for the proline content determination. Leaf discs were taken from the youngest fully grown 
leaf. For each sample, five leaf discs from different plants were placed in a test vial on ice and kept at $-2^{\circ} \mathrm{C}$ for 16 hours. Afterward, te mperature was decreased at a rate of $4^{\circ} \mathrm{C} / 105 \mathrm{~min}$. The test comprised four freezing temperature steps which were maintained for at least one hour $\left(-3^{\circ} \mathrm{C},-7^{\circ} \mathrm{C},-1^{\circ} \mathrm{C}\right.$, and $\left.-1^{\circ} \mathrm{C}\right)$. After each step of freezing, four leaf discs were taken from each genotype. These leaf discs were shaken in $20 \mathrm{ml}$ of pure water for 24 hours at $7^{\circ} \mathrm{C}$ and the electrical conductivity was measured by means of a microprocessor conductivity meter (LF 537) and a conductivity cell (LTA 01) immediately after shaking (C1) and after autoclaving to determine conductivity of total killed tissue (C2). Membrane stability index (MSI) was calculated according to Chandrasekar et al. (2000) as MSI =100[1-(C1/C2)]

Statistical analyses

For winter-hardiness, frost tolerance, total fatty acid composition in leaves, free proline content and membrane stability of leaves, sources of variation were tested for significance using Plabstat (Utz, 1991). For each trait, heritability of the genotypes was determined ( $h^{2}=$ genotypic variance / phenotypic variance). In case of significant differences between genotypes, LSD at $5 \%$ was used to identify superior genotypes (Steel and Torrie, 1981).

The Spearman rank correlation coefficient was calculated, rather than the Pearson correlation, in order to avoid an inflating effect from group mean differences between winter and spring genotypes (Steel and Torrie, 1981).

\section{Results and discussion}

Field trials

In most environments, the main diseases were chocolate spot due to Botrytis fabae and ascochyta blight due to Ascochyta fabae. The European cultivar Karl was rather resistant to Botrytis and Clipper appeared as most resistant to Ascochyta. In winter beans, lodging was more frequent than in spring beans: It causes losses in yield performance and an increase in disease infestation (Ghaouti and Link, 2007). Across all environments, Webo/1 and Bulldog/1 were the least lodging genotypes.

The analysis of variance showed significant differences between genotypes for grain yield and overwintering (Table 2). Highly significant genotype $x$ environment interactions $(G \times E)$ reflected specific adaptations and mis-adaptations of genotypes 
to single environments. In all environments, no spring beans survived the winter, and the European winter genotypes were on average more winter-hardy than the experimental lines. The highest overwintering was realized by Bulldog/1 ( 9 scoreunit) at Göttingen in 2004 with a yield of $2.9 \mathrm{t} \mathrm{ha}^{-1}$. In this environment, due to the mild winter (only 8 days with temperatures below $-6^{\circ} \mathrm{C}$ ), the highest mean overwintering (6.5 scoreunit) and highest mean yield $\left(2.4 \mathrm{t} \mathrm{ha}^{-1}\right)$ were observed. The highest yield was realized by the experimental line F7-29 and the European winter-hardy cultivar Karl $\left(4.1 \mathrm{t} \mathrm{ha}^{-1}\right)$ at Göttingen in 2006. However, in environments with intermediate or even harsh winter conditions, F7-29 performed poorly.

Across all environments, a group of superior genotypes for winter-hardiness was identified: Hiverna/2, Hiverna, Karl, Bulldog/1, and GöttWAB (Fig. 2). The experimental lines F7-(Cor1xBPL) performed less well than the experimental lines F4-(ScixCor1) and the cultivars (Fig. 2). The relatively good performance of the F4(ScixCor1) lines for overwintering and grain yield may be due to the fact that both parents (Côte d'Or/1 and Scirocco) are adapted to European environments.

As in barley (Rizza et al., 1994), under selective winter conditions faba bean winterhardiness seemed to determine to a large extent grain yield. Spearman's rank correlation coefficient between mean grain yield and mean overwintering was strong and highly significant $\left(r=0.828^{* \star}\right)$.

\section{Artificial frost}

Hardening significantly increased frost tolerance of all genotypes. Previous studies found similar results in faba beans and other crops (Herzog, 1987b; Rizza et al., 1994; Petcu and Terbea, 1995). In both hardened and unhardened treatments, spring genotypes were the most susceptible, whereas the experimental line F7(Cor1xBPL)-95 and the European winter cultivar Karl were the most frost tolerant. Significant correlations between the results of the two treatments showed that some favourable alleles involved in frost tolerance were similarly expressed in both treatments (Fig. 3).

The analysis of variance of frost tolerance showed significant differences between the two treatments. Response to frost was different among genotypes, and the genotype $x$ treatment interactions $(G \times T)$ were highly significant, showing that some genotypes had a greater increase in frost tolerance due to hardening than others 
(Table 3). This could be due to the differences among genotypes for their hardening response or to the requirement of some genotypes for a longer hardening period. The high heritability $\left(h^{2}=0.888\right)$ of the genotypes for frost tolerance promises a very efficient selection in such experiments (Table 3).

Provocative frost

Duration of hardening had a large and significant effect on faba bean frost tolerance. After three weeks of hardening, AUSPC-PFT was 2030 scoreunit ${ }^{\circ} \mathrm{C} h$, after two weeks AUSPC-PFT was 2055 scoreunit ${ }^{\circ} \mathrm{h}$, and after one week AUSPC-PFT was 2500 scoreunit ${ }^{\circ} \mathrm{C} h$. Thus, seedlings required more than one week of hardening to reach maximum frost tolerance.

Highly significant differences between genotypes were observed for frost tolerance. Using natural frost for potted seedlings was clearly an efficient method to screen for frost tolerance. The absence of significant $G \times T$ interactions resulted in a very high estimate for the reproducibility of this method $\left(h^{2}=0.971\right.$; Table 4$)$.

As in the artificial frost tests, the three spring beans were the most susceptible entries, and the experimental line F7-(Cor1xBPL)-95 was the most frost tolerant one. Artificial frost tests and provocative frost tests revealed the frost tolerance potential of the experimental lines which was not translated into corresponding winter-hardiness in the multi-environment field trials. Moreover, those two methods confirmed the relatively weak frost tolerance of winter-hardy genotypes such as Bulldog/1 (cf. Fig. 2 and Fig. 3). Herzog (1989) previously observed the lower frost tolerance of the cultivar Bulldog in comparison to other European winter cultivars.

Fatty acids

Among the ten fatty acids identified in leaves, six represented more than $95 \%$ of the total fatty acid composition in both treatments. The main fatty acid was linolenic acid (C18:3). Hardening increased $\mathrm{C} 18: 3$ content in leaves by $6.28 \%$, whereas palmitic acid $(\mathrm{C} 16: 0)$ was decreased by $0.81 \%$, stearic acid $(\mathrm{C} 18: 0)$ by $0.07 \%$, oleic acid (C18:1) by 3.24\%, linoleic acid (C18:2) 1.70\%, and stearidonic acid (C18:4) by $0.89 \%$ (Table 5). Similar findings on the effect of hardening on total fatty acid composition were found, e.g., by Samala et al. (1998) on bermudagrass cv Midiron, Cyril et al. (2002) on paspalum grass cv Seashore, and by Falcone et al. (2004) on Arabidopsis. 
The decrease of C18:1 due to hardening was significantly and negatively correlated to the increase of C18:3 (Fig. 4, Spearman's rank correlation $r=-0.625^{\star \star}$ ). Thus, hardening promoted the desaturation of C18:1 to C18:3. Moreover, the increase of polyunsaturated fatty acid content due to hardening $(\mathrm{C} 18: 2+\mathrm{C} 18: 3)$ was significantly higher in genotypes with a high initial content of C18:1 in unhardened leaves $(r=$ $\left.0.711^{* *}\right)$. Desaturase enzyme activity during hardening is probably the cause of C18:2+C18:3 increases in the cells, especially in the cell membranes. Molecular studies have indicated overexpression of desaturase genes during hardening in several plant species (Gibson et al., 1994; Ohno et al., 2001).

The relationship between the changes in $\mathrm{C} 18: 1$ and $\mathrm{C} 18: 3$ content due to hardening was confirmed by the fact that the treatment effect was significant for only those two fatty acids. Furthermore, the effect of genotype was significant for all fatty acids and the $G \times T$ interactions was not significant (Table 6). Thus, the hardening effect on all genotypes was similar for fatty acid composition. Merkur (a spring genotype) had the lowest increase of C18:3, and the experimental line F7-(Cor1xBPL)-5 the highest. Amongst others, the European winter cultivar Karl and the line F7-(Cor1xBPL)-95 increased significantly and markedly their C18:3 content following hardening.

Free proline

Proline accumulation during hardening was observed in all genotypes and differences between genotypes for free proline content were significant (Table 7). The three spring beans and Bulldog/1 (European winter type) had the lowest accumulation of free proline. The experimental lines F7-(Cor1xBPL)-89, F7(Cor1xBPL)-95, and GöttWAB had the highest accumulation of free proline. The role of proline in the stress response of plants is not quite clear (review: Kuznetsov and Shevyakova 1999). It is often considered as osmotically active substance, but its contribution to osmotic adaptation in legumes is small (Shabala et al. 2000, Sanchez et al. 2004). Proline probably also functions in stabilizing macromolecules and membranes (Samuel et al. 1997).

Membrane stability

Alterations in structure and function of cell membranes are known to occur already in the beginning of stress injury. As membranes are essential for structure as well as 
metabolism of plant cells, the extent of membrane damage could give information about the tolerance of cells and tissues to stress exposure.

Genotypes were significantly different for their average membrane stability (Table 8). At mild $\left(-3^{\circ} \mathrm{C}\right.$ and -79 and severe $\left(-15^{\circ} \mathrm{C}\right)$ freezing temperatures, the variation in membrane stability index (MSI) among genotypes was low, and the spring beans were not significantly different from the European winter genotypes and the experimental lines (details not shown). Those freezing temperatures were apparently inappropriate to discriminate either between winter and spring beans or among winter beans. At $-11^{\circ} \mathrm{C}$, however, very high and significant variation of the trait among winter beans was observed; the three spring beans and Bulldog/ 1 had the lowest MSI, whereas the experimental line F7-(Cor1xBPL)-95 had the highest MSI.

\section{Correlation analyses}

Winter-hardiness can be considered as a joint result of frost tolerance, together with resistances against biotic stress and against additional adverse climatic conditions during winter and further aspects. Based on correlation coefficients, that part of winter-hardiness that can be explained by frost tolerance was estimated. For both methods (artificial frost tests, provocative frost tests), correlation coefficients with overwintering were significant, confirming that frost tolerance is a component of faba bean winter-hardiness as in other crops (Auld et al., 1983; Rizza et al., 1994; Petcu and Terbea, 1995). Still, the coefficients showed that it was not an exhaustive component in our experiments. Whereas the British winter genotype Bulldog/ 1 was selected among the best genotypes for its winter-hardiness, it had a relatively low frost tolerance in artificial frost tests and provocative frost tests. On the other hand, the experimental line F7-(Cor1xBPL)-95 had low winter-hardiness, but high frost tolerance. There are additional features that influence winter-hardiness based on field trials other than just frost tolerance as demonstrated by artificial frost tests. In the frost chamber, at the lowest freezing temperature step $\left(-21^{\circ} \mathrm{C}\right)$, the temperature at the root level was $-15^{\circ} \mathrm{C}$. In natural conditions, the soil temperature does not reach such an extreme temperature. In field trials, with the given agro-ecologically very different locations (like Central Germany and Estonia), winter-hardiness was expected to be influenced by several characteristics other than freezing temperatures. Bulldog/1 and F7-(Cor1xBPL)-95 seemed to show complementary differences for such other characteristics. This study has showed that neither of the 
two methods could substitute for field trials, but could complement them by identifying promising sources for improved winter-hardiness (Fig. 5).

In the literature it is established that polyunsaturated fatty acid content (C18:2 and C18:3) is associated with increased frost tolerance, and consequently winterhardiness. In this study, a significant correlation was found between C18:1 content in unhardened leaves and overwintering $\left(r=-0.363^{\star}\right)$, but no significant correlations were found between winter-hardiness and C18:2 or C18:3 content in either treatment. On the other hand, the changes in $\mathrm{C} 18: 2+\mathrm{C} 18: 3$ content in leaves due to hardening were significantly correlated to overwintering ( $r=0.393^{*}$; Table 9; at Göttingen in 2006 this coefficient was $\left.r=0.549^{\star *}\right)$; to AUSPC-AFT $\left(r=-0.480^{* *}\right)$, and to unhardened AUSPC-AFT ( $\left.r=-0.415^{*}\right)$. The correlation with AUSPC-PFT was similar but not significant $(r=-0.323)$. Thus, accumulation of polyunsaturated fatty acids after exposure to low non-freezing temperatures was a component of frost tolerance and winter-hardiness (Fig. 6). This trait was more related to frost tolerance than to winter-hardiness.

Accumulation of free proline plays an important role in frost tolerance and most of all regarding the increase of frost tolerance during hardening in a range of crops (Hordeum sp.: Dobslaw and Bielka, 1988; Tantau et al., 2004, Triticum sp.: Dörffling et al., 1990). Accumulation of proline was associated with chilling tolerance in cultured cells of Zea (Xin and Li, 1993) and with frost tolerance in Solanum cells (Hellergren and Li, 1981). In legume plants, first investigations indicate a relationship between proline accumulation and chilling tolerance (Cicer sp.: Nayyar et al., 2005) and freezing tolerance (Trifolium sp.: Rosnes et al., 1993) as well.

In the present study, accumulation of free proline was found to be a major component of frost tolerance and winter hardiness. The correlation with mean overwintering was $r=0.475^{\star *}$ (at Göttingen in 2006, $r=0.556^{\star *}$ ), with hardened AUSPC-AFT $r=-$ $0.584^{\star *}$, with unhardened AUSPC-AFT $r=-0.339$, and with AUSPC-PFT $r=-0.610^{* *}$ (Table 9). As for fatty acids, free proline content in hardened material was more related to frost tolerance than winter-hardiness. Both traits, winter-hardiness and free proline content, identified similar sets of inferior and superior genotypes (Fig. 7). Genotypes with low winter-hardiness had a low accumulation of free proline, whereas most genotypes with superior winter-hardiness had high accumulation. The main differences between those two methods came from a presumed tolerance (as 
Bulldog/1) and susceptibility (as F7-(Cor1xBPL)-95 and F7-(Cor1xBPL)-89) of genotypes to the diverse stress occurring in the field environments.

Correlations between membrane stability index and overwintering, and frost tolerance measured in both methods were maximal at a freezing temperature of $-11^{\circ} \mathrm{C}$ (Fig. 8). At this temperature, correlation with mean overwintering was $r=0.322$ (at Göttingen in 2006, $r=0.456^{* *}$ ), with AUSPC-PFT $r=-0.709^{* *}$, with hardened AUSPC-AFT $r=-$ $0.675^{\star *}$, and with unhardened AUSPC-AFT $r=-0.659^{* *}$. Thus, results of MSI could be used to pre-select for frost tolerance.

Altogether, these correlation results have strongly indicated that changes in fatty acid content, proline content, and membrane stability index could be used to explain important proportions of the variation in frost tolerance.

From these results it may be concluded that F7-(Cor1xBPL)-95 expressed a high frost tolerance, whereas Bulldog/1 owed its proven high winter-hardiness to its adaptation to aspects of European winters other than frost. Thus, marked breeding progress for winter-hardiness can be expected by selecting in the offspring of a cross between Bulldog/1 and F7-(Cor1xBPL)-95.

Frost tolerance and its three related traits showed low correlation with the mean overwintering across all environments. Within single environments, however, these traits were more often significantly correlated with overwintering where frost stress was intermediate.

At Göttingen in 2006, the correlation between overwintering and frost tolerance measured by the artificial frost test was $r=-0.570^{\star *}$, and $r=-0.737^{* *}$ with the provocative frost test (Fig. 9). This last coefficient might be inflated because the provocative frost tests ran also during the winter 2006.

The artificial frost test, provocative frost test, leaf changes in polyunsaturated fatty acids, free proline content and membrane stability index provide measures that could be used to select faba bean genotypes that survive well in moderately severe winters. It seems reasonable to use field trials and probably provocative frost tests for mass screening. The other methods may be very useful to identify parents for crosses that are complementary in several sub-aspects of winter hardiness, giving the prospect of useful transgression. 


\section{Acknowledgements}

This work was supported by funds from the commission of the European Communities, Research Program Quality of Life and Management of Living Resources, QLK5-2001-02307, "Eufaba". It does not necessarily reflect its views and in no way anticipates the Commissions' future policy in this area. The authors thank NPZ-Lembke Company for their financial contribution. Furthermore, we thank Dr. Olaf Sass, Johanna Winkler, Miroslav Hybl, and Lea Narits for conducting field experiments in their locations, Fred Stoddard for his valuable constructive critics, and Dr D. Rubiales, Cordoba, for coordinating the project EUFABA. 
Table I-1. Faba bean germplasm used in experiments on frost tolerance, comprising 12 European winter cultivars and derived lines, 12 experimental lines and seven checks.

\begin{tabular}{lll}
\hline \multicolumn{1}{c}{ Cultivars and lines } & \multicolumn{1}{c}{ Experimental inbred lines } & Check cultivars and lines \\
\hline Silver & F7 (Côte d'Or/1 x BPL 4628)-29 & Pistache (spring type) \\
Target & F7 (Côte d'Or/1 x BPL 4628)-66 & Merkur (spring type) \\
Karl & F7 (Côte d'Or/1 x BPL 4628)-95 & Mythos (spring type) \\
GöttWAB & F7 (Côte d'Or/1 x BPL 4628)-5 & Winter bean population \\
Punch & F7 (Côte d'Or/1 x BPL 4628)-50 & Hiverna \\
Striker & F7 (Côte d'Or/1 x BPL 4628)-89 & Côte d'Or/1 il \\
Clipper & F7 (Côte d'Or/1 x BPL 4628)-49 & BPL 4628 (ICARDA \\
Irena & F4 (Scirocco x Côte d'Or/1)-3028-1 & Bean Pure Line) \\
Diva & F4 (Scirocco x Côte d'Or/1)-3028-2 & \\
Bulldog $/ 1^{\text {il }}$ & F4 (Scirocco x Côte d'Or/1)-3028-3 & \\
Hiverna/2 ${ }^{\text {il }}$ & F4 (Scirocco x Côte d'Or/1)-3029-1 & \\
Webo/1 & F4 (Scirocco x Côte d'Or/1)-3033-1 & \\
\hline "inbred line derived from commercial cultivar &
\end{tabular}

Table I-2. Analysis of variance of grain yield $\left(\mathrm{kg} \mathrm{ha}^{-1}\right)$ of 29 faba bean genotypes in ten environments and overwintering (scoreunit) in 12 environments.

\begin{tabular}{lrrrrrr}
\hline & \multicolumn{3}{c}{ Grain yield } & \multicolumn{3}{c}{ Overwintering } \\
\hline Sources of variation & DF & MS $\left(\times 10^{4}\right)$ & F-value & DF & MS & F-value \\
\hline Environments & 9 & 2107.50 & $64.45^{\star *}$ & 11 & 99.06 & $53.30^{\star *}$ \\
Genotypes & 28 & 188.96 & $5.78^{\star *}$ & 28 & 18.47 & $9.94^{\star *}$ \\
Gx E & 249 & 32.69 & $9.74^{\star *}$ & 304 & 1.86 & $1.97^{\star *}$ \\
Error & 230 & 3.35 & & 269 & 0.94 & \\
\hline
\end{tabular}

${ }^{*},{ }^{* *}$, significant at 0.05 and 0.01 level of the probability, respectively.

Table I-3. Analysis of variance of frost tolerance of 31 faba bean genotypes, hardened and unhardened, assessed by artificial frost test (AUSPC-AFT, scoreunit ${ }^{\circ} \mathrm{h}$ ).

\begin{tabular}{lrrr}
\hline Sources of variation & DF & MS $\left(\times 10^{4}\right)$ & F-value \\
\hline Treatments (hardening) & 1 & 18402.29 & $163.16^{\star *}$ \\
Loads / Treatments & 4 & 112.79 & $17.14^{\star *}$ \\
Replicates / L x T & 12 & 6.58 & $6.12^{\star *}$ \\
Genotypes & 30 & 21.90 & $8.92^{\star *}$ \\
Genotype x Treatments & 30 & 5.17 & $2.11^{\star *}$ \\
G x L / T & 120 & 2.46 & $2.28^{\star *}$ \\
Error & 360 & 1.08 & \\
\hline
\end{tabular}

${ }^{*},{ }^{* \star}$ significant at the 0.05 and 0.01 level of the probability, respectively. 
Table I-4. Analysis of variance of frost tolerance in 31 faba bean genotypes hardened for one, two or three weeks, assessed by provocative frost tests (AUSPC-PFT, scoreunit ${ }^{\circ} \mathrm{h}$ ).

\begin{tabular}{lccc}
\hline Sources of variation & DF & MS $\left(\times 10^{4}\right)$ & F-value \\
\hline Treatments & 2 & 347.87 & $79.12^{\star *}$ \\
Genotypes & 30 & 141.70 & $34.12^{\star *}$ \\
Genotype x Treatments & 60 & 4.15 & 0.94 \\
Error & 93 & 4.40 & \\
\hline
\end{tabular}

${ }^{*},{ }^{* *}$ significant at the 0.05 and 0.01 level of the probability, respectively.

Table I-5. Mean fatty acid content in hardened and unhardened leaves (\%) of 30 faba bean genotypes.

\begin{tabular}{lrrrrrr}
\hline Treatment & C16:0 & C18:0 & C18:1 & C18:2 & C18:3 & C18:4 \\
\hline Hardened & 9.80 & 1.20 & 4.00 & 18.10 & 57.10 & 5.70 \\
Unhardened & 10.60 & 1.30 & 7.20 & 19.80 & 50.80 & 6.60 \\
Standard Error & 0.31 & 0.07 & 0.56 & 0.67 & 1.04 & 0.32 \\
\hline
\end{tabular}

Table I-6. Analysis of variance (F-values) of the main fatty acid contents (\%) in hardened and unhardened leaves of 30 faba bean genotypes.

\begin{tabular}{|c|c|c|c|c|c|c|c|}
\hline Sources of variation & $\mathrm{DF}$ & C16:0 & C18:0 & C18:1 & C18:2 & C18:3 & C18:4 \\
\hline Treatments & 1 & 3.14 & 0.61 & $81.37^{\star *}$ & 4.31 & $39.73^{\star \star}$ & 2.07 \\
\hline Experiments / Treatments & 4 & 4.05 & $6.34^{*}$ & 1.36 & $11.30^{* *}$ & 2.43 & $5.60^{*}$ \\
\hline Replicates / E x T & 6 & $13.79 * *$ & $5.43^{* *}$ & $18.66^{\star *}$ & $4.37^{\star \star}$ & $17.96^{* *}$ & $15.07^{* *}$ \\
\hline Genotypes & 29 & $3.30^{* *}$ & $2.35^{\star *}$ & $4.40^{* *}$ & $1.86^{*}$ & $2.50^{* *}$ & $2.74^{\star \star}$ \\
\hline Genotype x Treatments & 29 & 1.11 & 0.86 & 1.37 & 0.63 & 1.06 & 1.19 \\
\hline $\mathrm{G} \times \mathrm{E} / \mathrm{T}$ & 116 & $2.99^{* *}$ & $1.71^{* *}$ & $4.70^{* *}$ & $4.81^{* *}$ & $3.86^{\star \star}$ & $2.84^{* *}$ \\
\hline$R \times G / E \times T$ & 174 & 1.17 & $1.76^{* *}$ & $1.74^{\star *}$ & 0.91 & $1.65^{\star \star}$ & 1.03 \\
\hline Error & 360 & & & & & & \\
\hline
\end{tabular}

Table I-7. Analysis of variance of proline content (\%) in hardened leaves of 29 faba bean genotypes.

\begin{tabular}{lcrc}
\hline Sources of variation & DF & MS & F-value \\
\hline Genotypes & 28 & 1106.08 & $119.49^{\star *}$ \\
Error & 77 & 9.26 & \\
\hline
\end{tabular}

${ }^{*},{ }^{* *}$ significant at the 0.05 and 0.01 level of the probability, respectively.

Table I-8. Analysis of variance of membrane stability index at four temperature steps in 28 faba bean genotypes.

\begin{tabular}{lrrr}
\hline Sources of variation & DF & MS & F-value \\
\hline Temperatures & 3 & 102176.80 & $834.20^{\star *}$ \\
Genotypes & 27 & 612.78 & $34.99^{\star *}$ \\
Genotype x Treatments & 81 & 124.39 & $7.10^{\star *}$ \\
Error & 318 & 17.51 & \\
\hline
\end{tabular}

${ }^{*},{ }^{\star \star}$ significant at the 0.05 and 0.01 level of the probability, respectively. 
Table 1-9. Spearman's rank correlation coefficient between mean overwintering, hardened AUSPC-AFT, AUSPC-PFT, content of C18:1 unhardened, changes in polyunsaturated fatty acids $(\mathrm{C} 18: 2+\mathrm{C} 18: 3)$, and proline content.

\begin{tabular}{lccccc}
\hline Traits & $\begin{array}{c}\text { Mean } \\
\text { overwintering }\end{array}$ & $\begin{array}{c}\text { Hardened } \\
\text { AUSPC-AFT }\end{array}$ & $\begin{array}{c}\text { AUSPC- } \\
\text { PFT }\end{array}$ & $\begin{array}{c}\text { C18:1 content } \\
\text { unhardened }\end{array}$ & $\begin{array}{c}\text { Changes in } \\
\text { C18:2+C18:3 }\end{array}$ \\
\hline $\begin{array}{l}\text { Hardened } \\
\text { AUSPC-AFT }\end{array}$ & $-0.413^{*}$ & - & & \\
AUSPC-PFT & $-0.449^{*}$ & $0.688^{* *}$ & - & \\
$\begin{array}{l}\text { C18:1 } \\
\text { content } \\
\text { (unhardened) }\end{array}$ & $0.363^{*}$ & $-0.549^{* *}$ & $-0.462^{*}$ & & - \\
$\begin{array}{l}\text { Changes in } \\
\text { C18:2+C18:3 }\end{array}$ & $0.393^{*}$ & $-0.480^{* *}$ & -0.323 & $0.711^{* *}$ & \\
Proline & $0.475^{* *}$ & $-0.584^{* *}$ & $-0.610^{* *}$ & $0.412^{*}$ & 0.329 \\
\hline
\end{tabular}

${ }^{*},{ }^{* *}$ significant at the 0.05 and 0.01 level of the probability, respectively.

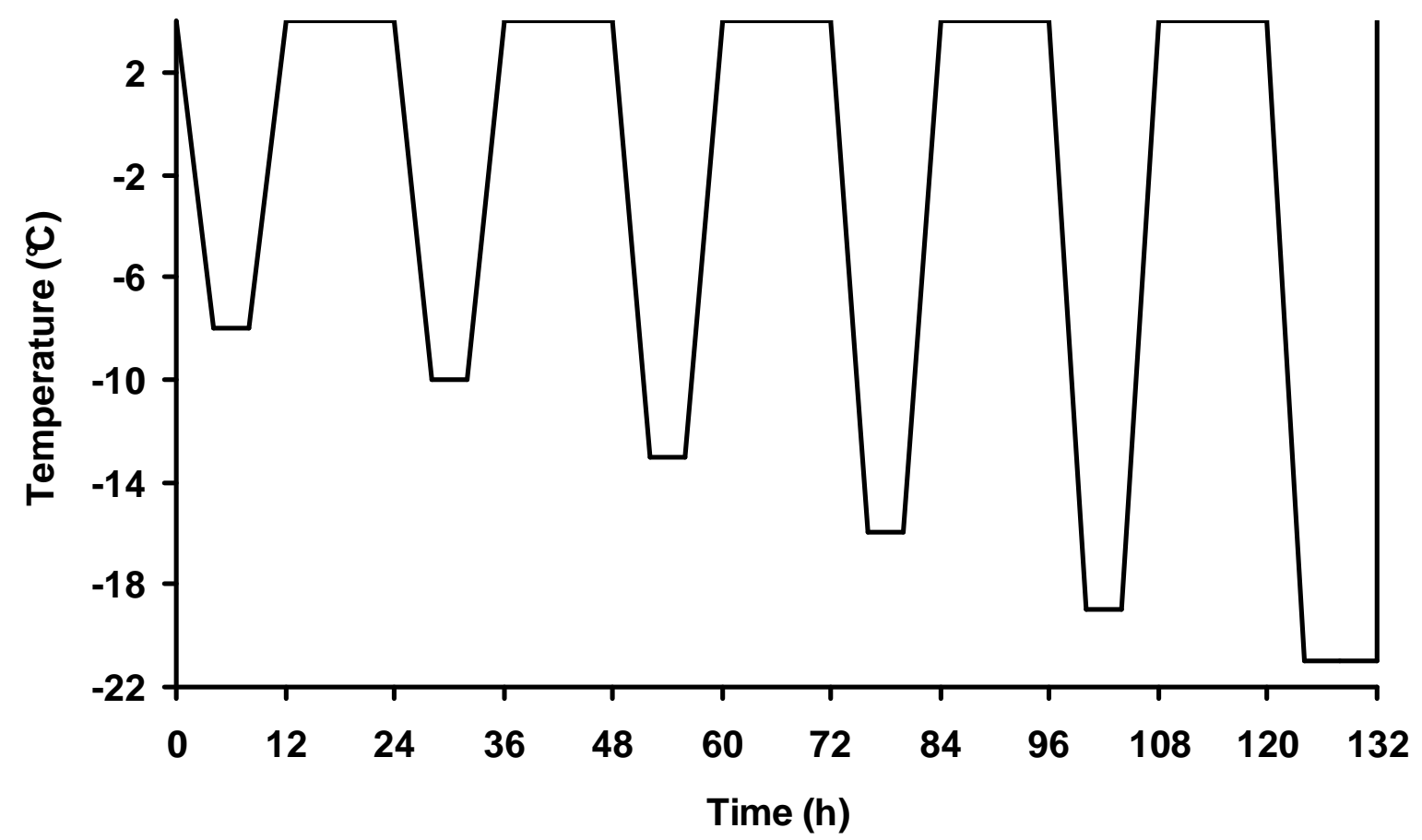

Fig. I-1. Temperature profile of the artificial frost test. 
○Checks $\quad \square$ Cultivars $\quad \Delta$ (Cor1xBPL) lines $\triangle$ (Cor1xSci) lines

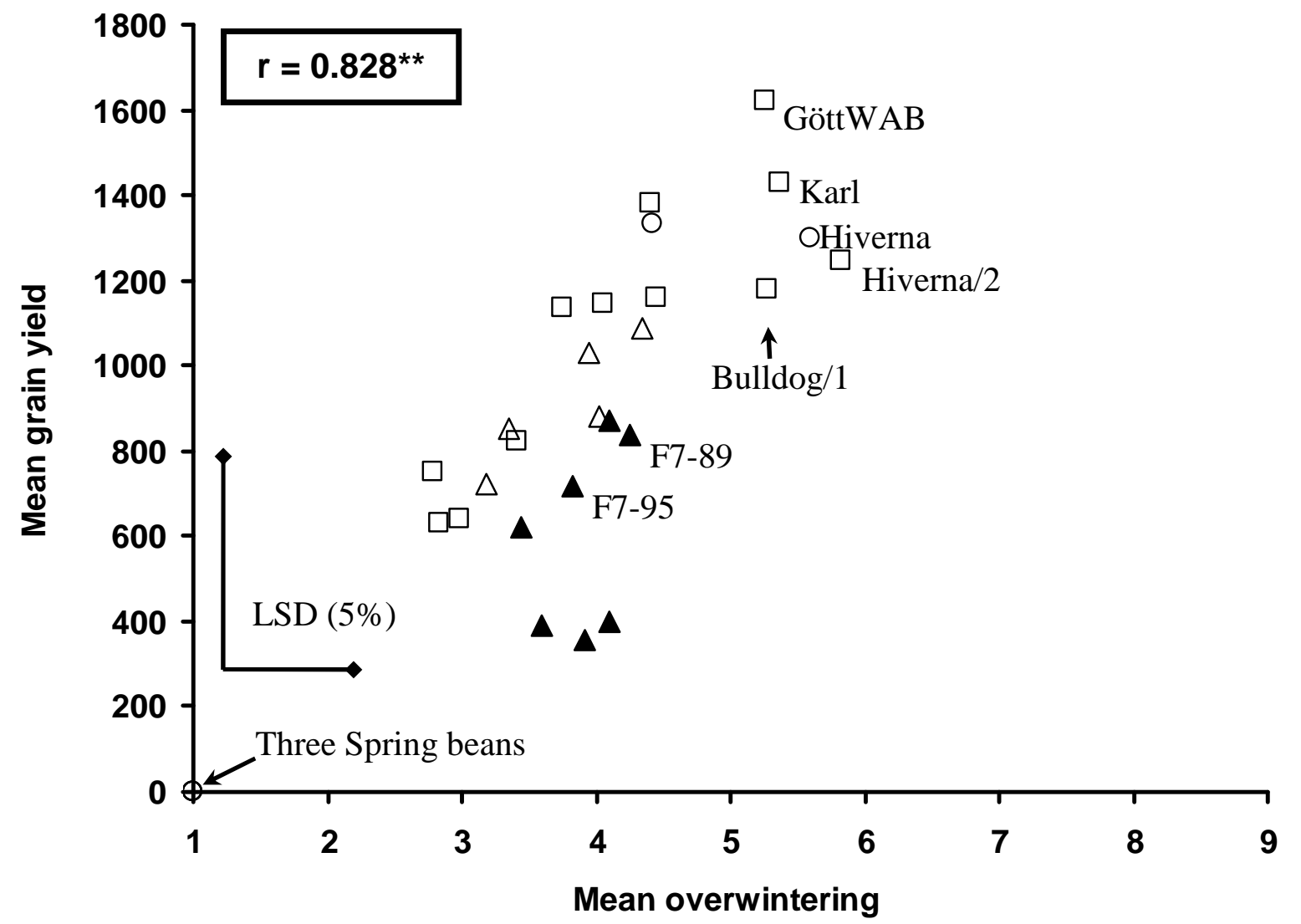

Fig. I-2. Mean overwintering (scoreunit) and grain yield ( $\mathrm{kg} \mathrm{ha}^{-1}$ ) across all environments. 


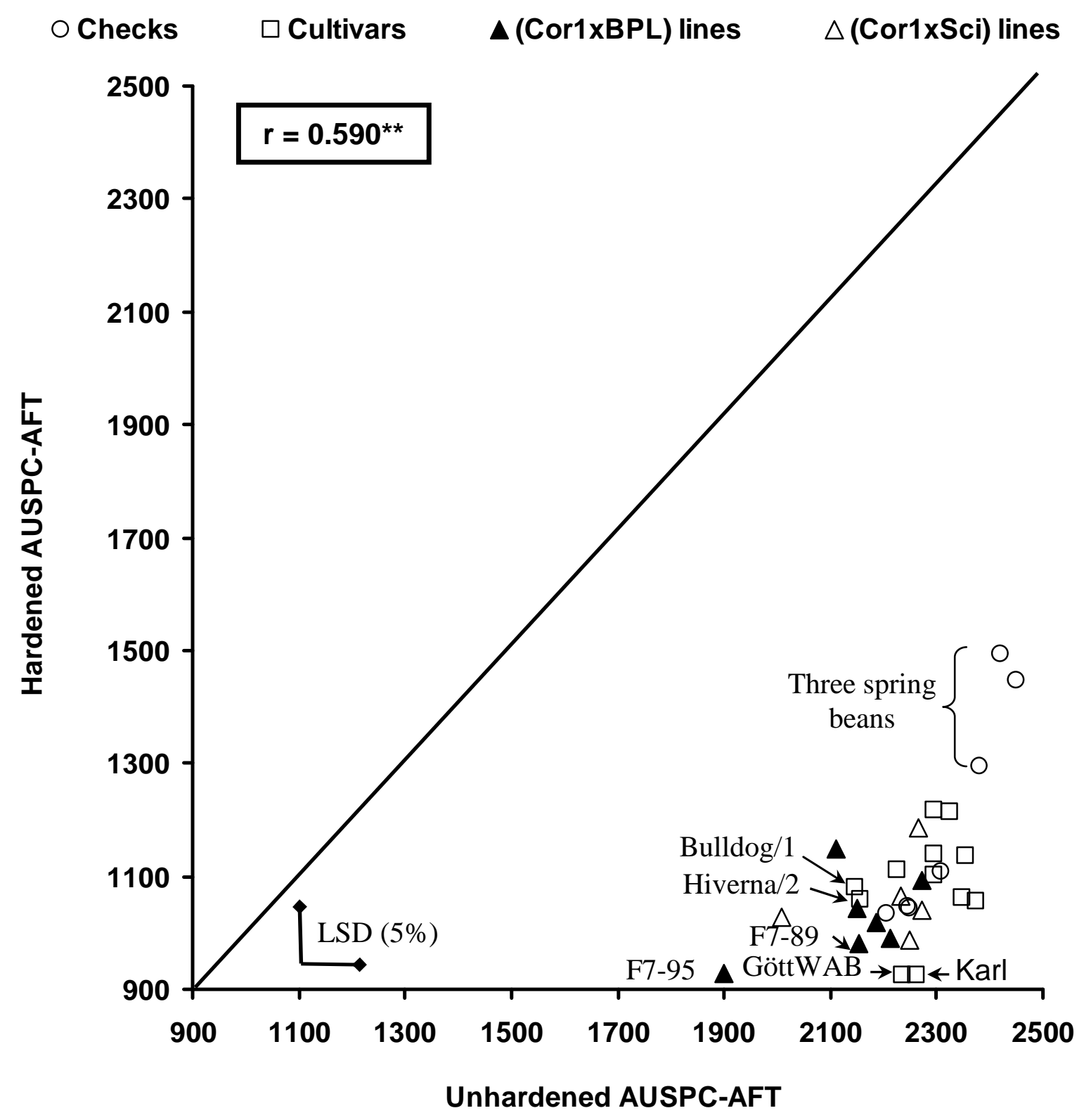

Fig. I-3. Unhardened AUSPC-AFT and hardened AUSPC-AFT (scoreunit ${ }^{\circ} \mathrm{C}$ ). 
OChecks $\square$ Cultivars $\triangle \mathrm{F} 4-($ Cor1 $x$ Sci) $\quad \Delta$ F7-(Cor1 x BPL)

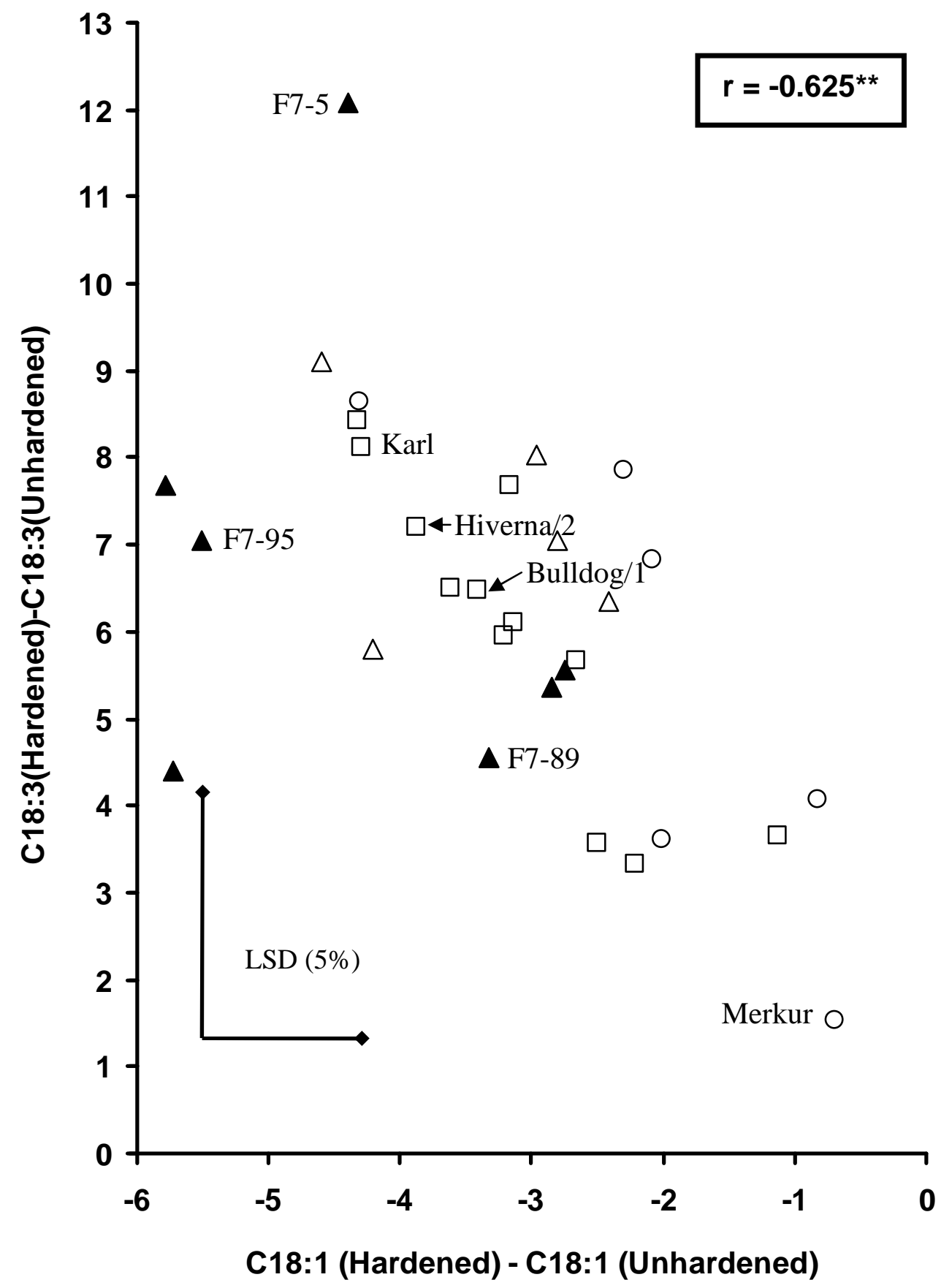

Fig. I-4. Mean changes in C18:1 content and in C18:3 content due to hardening. 
OChecks $\square$ Cultivars $\Delta$ (Cor1xBPL) lines $\Delta$ (Cor1xSci) lines

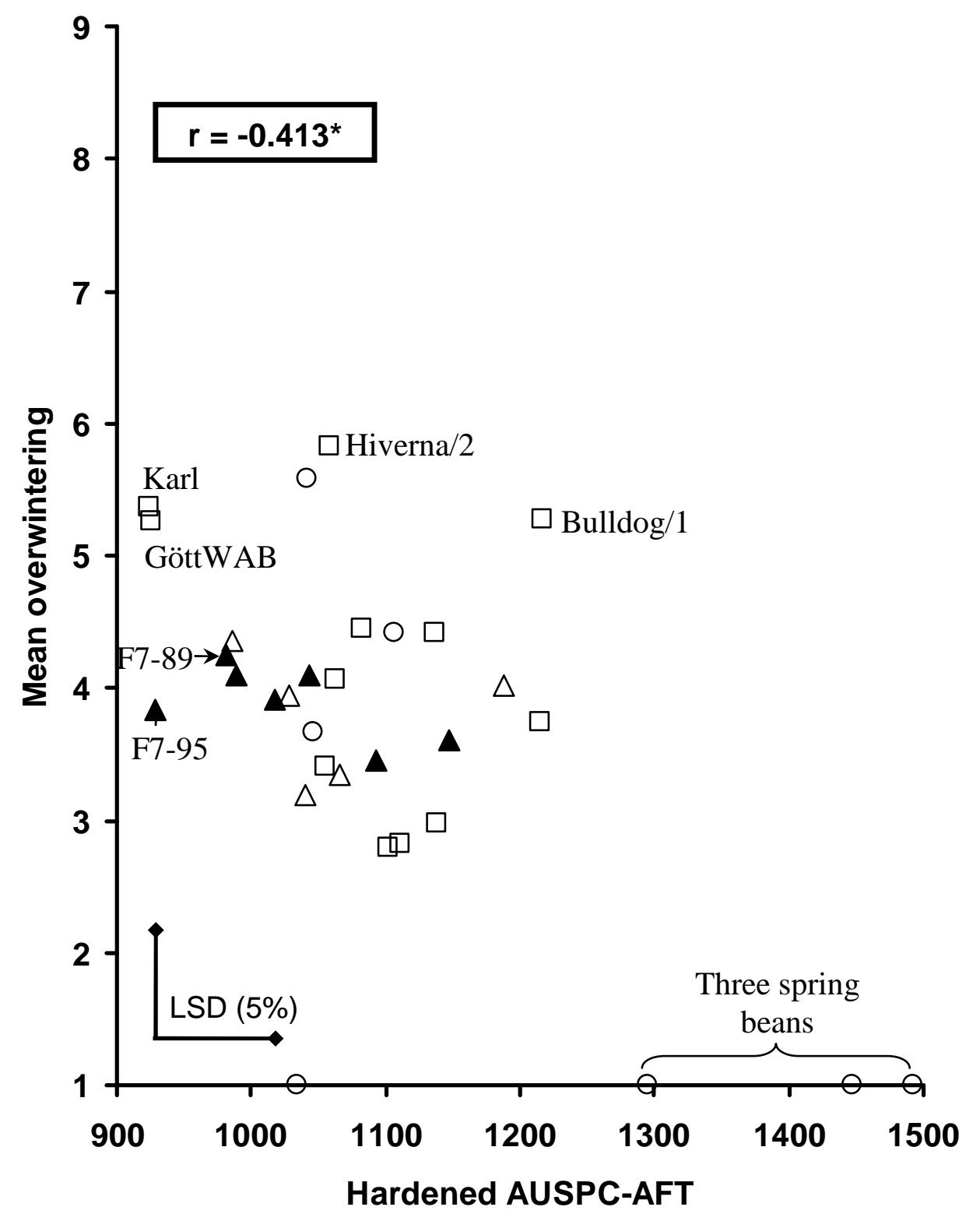

Fig. 1-5. Frost tolerance measured by hardened artificial frost test and mean overwintering across all environments. 


\section{OChecks $\square$ Cultivars $\Delta$ (Cor1xBPL) lines $\Delta$ (Cor1xSci) lines}

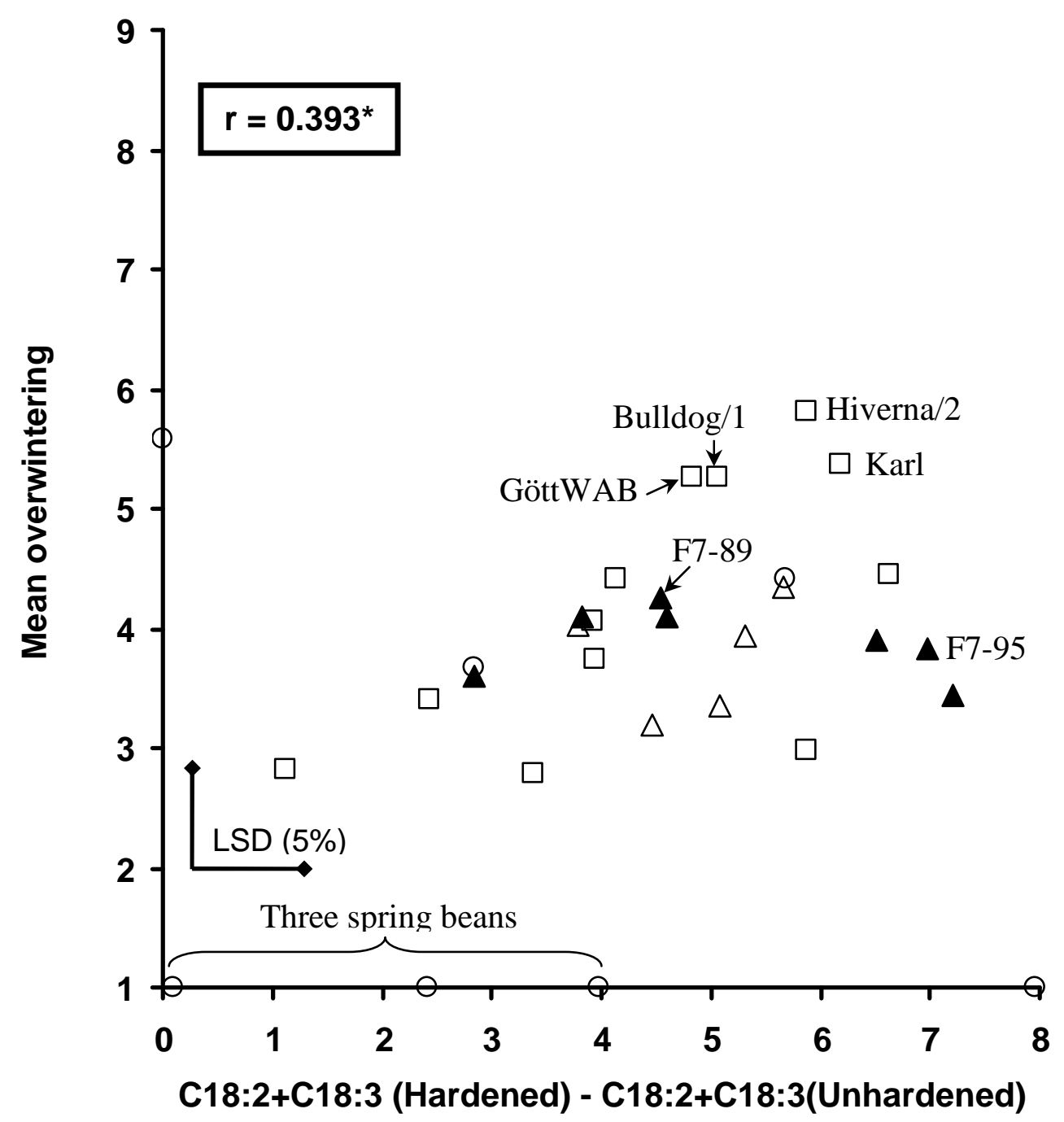

Fig. I-6. Mean changes in polyunsaturated fatty acids due to hardening and mean overwintering across all environments. 
OChecks $\square$ Cultivars $\Delta$ (Cor1xBPL) lines $\Delta$ (Cor1xSci) lines

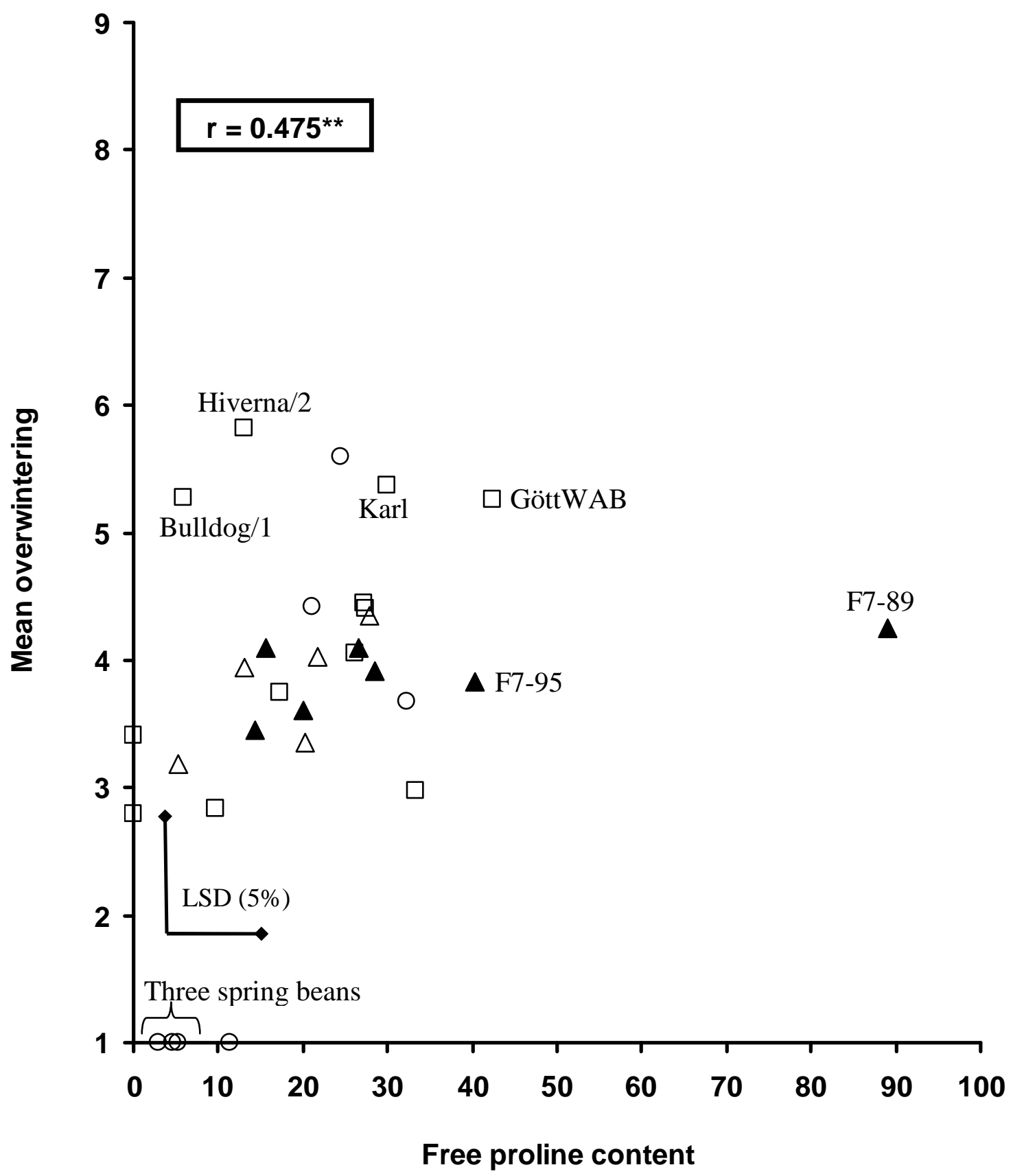

Fig. I-7. Accumulation of free proline after hardening and mean overwintering across all environments. 


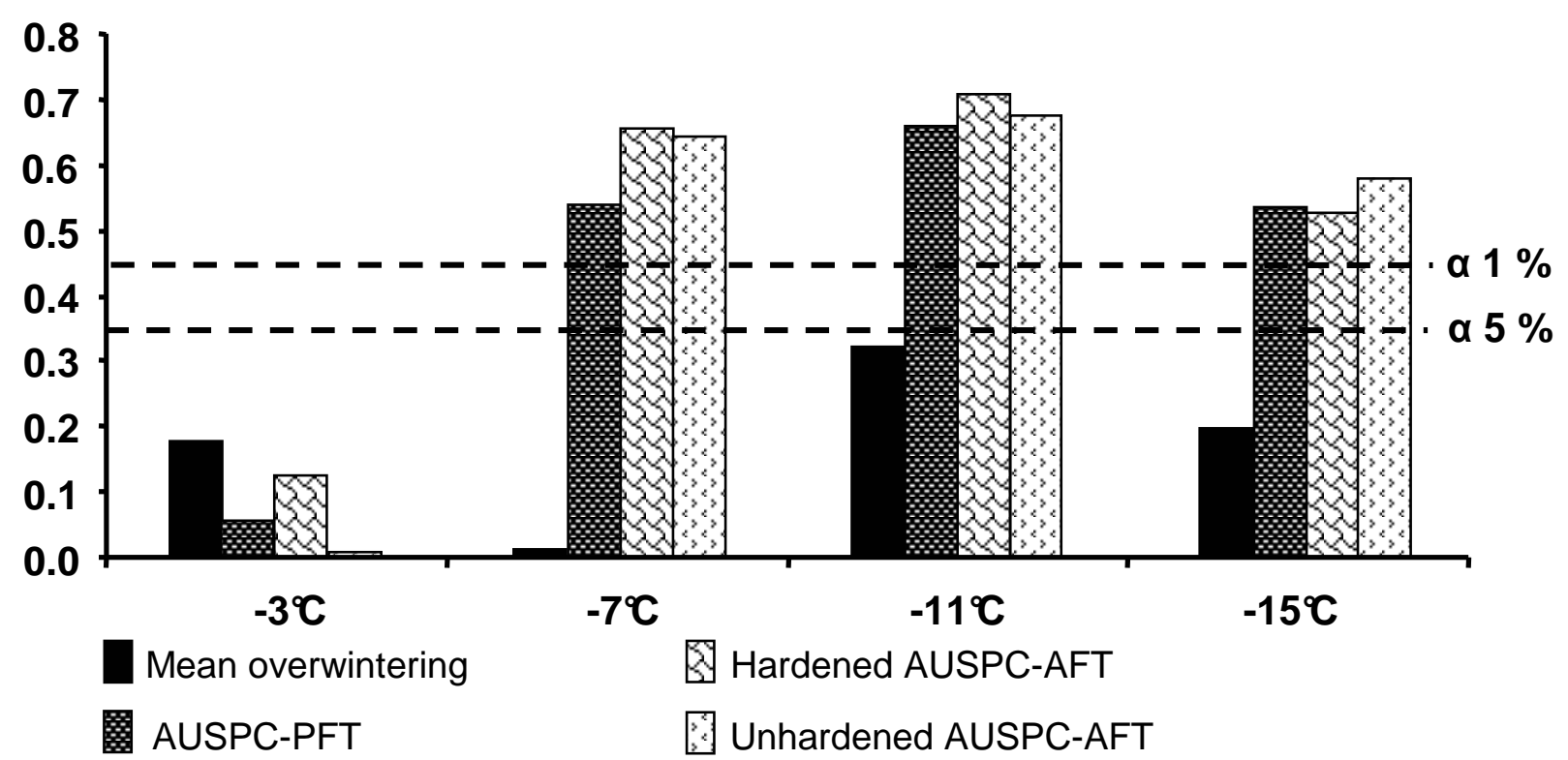

Fig. I-8. Spearman's rank correlation coefficient between the membrane stability index (measured at four freezing temperatures) and four further traits: mean overwintering, AUSPC-PFT, AUSPC-AFT hardened and unhardened.

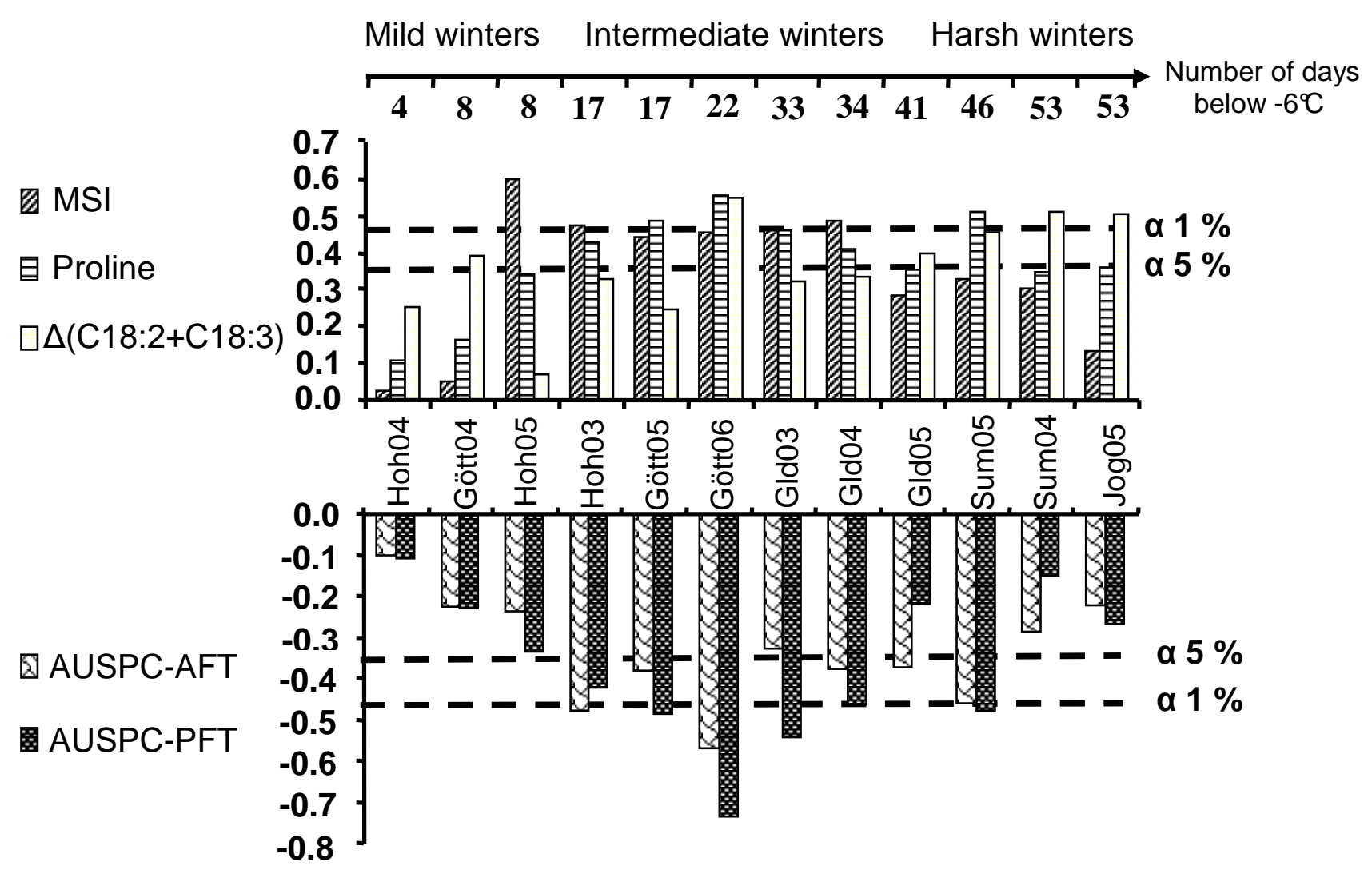

Fig. I-9. Spearman's rank correlations coefficient between overwintering in each environment with five further traits: the three related to frost tolerance, i.e., membrane stability index, free proline content, changes in polyunsaturated fatty acids, and with frost tolerance (AUSPC-AFT hardened and AUSPC-PFT). 


\section{References}

Auld, D.L., R.L. Ditterline, G.A. Murray, and J.B. Swensen. 1983. Screening peas for winter-hardiness under field and laboratory conditions. Crop Sci. 23:85-88.

Badaruddin,M., and D.W. Meyer. 2001. Factors modifying frost tolerance of legume species. Crop Sci. 41:1911-1916.

Bates, L.S., R.P. Waldren, and J.D. Teare. 1973. Rapid determination of free proline for water stress studies. Plant Soil. 39:205-207.

Bond, D.A., G.J. Jellis, G.G. Rowland, J. Le Guen, L.D. Robertson, S.A. Khalil, and L. Li-Juan. 1994. Present status and future strategy in breeding faba beans (Vicia faba L.) for resistance to biotic and abiotic stresses. Euphytica. 73:151-166.

Bouhassan, A., M. Sadiki, and B. Tivoli. 2004. Evaluation of a collection of faba bean (Vicia faba L.) genotypes originating from the Maghreb for resistance to chocolate spot (Botrytis fabae) by assessment in field and laboratory. Euphytica. 135:55-62.

Chandrasekar, V., R.K. Sairam, and G.C. Srivastava. 2000. Physiological and biochemical responses of hexaploid and tetraploid wheat to drought stress. J. Agron. Crop Sci. 185:219-227.

Cyril, J., G.L. Powell, R.R. Duncan, and W.V. Baird. 2002. Changes in membrane polar lipid fatty acids of Seashore Paspalum in response to low temperature exposure. Crop Sci. 42:2031-2037.

Davidson, N.J., and J.B. Reid. 1987. The influence of hardening and waterlogging on the frost resistance of subalpine eucalypts. Aust. J. bot. 35:91-101.

Davis, D.L., and W.B. Gilbert. 1970. Winter hardiness and changes in soluble protein fractions of bermudagrass. Crop Sci. 10:7-9.

Dobslaw, S., and S. Bielka. 1988. Untersuchungen zur Ermittlung des Frosttoleranzgrades bei Wintergerste mittels Prolinakkumulation. 1. Prüfung am Indikatorsortiment. Archiv für Züchtungsforschung, Berlin 18:235-240.

Dörffling, K., G. Schulenburg, G. Lesselich, and H. Dörffling. 1990. Abscisic acid and proline levels in cold hardened winter wheat leaves in relation to variety-specific differences in freezing resistance. J. Agron. Crop Sci. 
Dörffling, K., H. Dörffling, G. Lesselich, E. Luck, C. Zimmermann, G. Melz, and H.U. Jürgens. 1997. Heritable improvement of frost tolerance in winter wheat by in vitro-selection of hydroxyproline-resistant proline overproducing mutants. Euphytica. 93:1-10.

Duc, G., and F. PetitJean. 1995. Study of inheritance of freezing tolerance in Vicia faba L. 2nd European Conference on Grain Legumes. Copenhagen. Denmark. 11-15 July 1995.

Falcone, D.L., J. P. Ogas, and C.R. Somerville. 2004. Regulation of membrane fatty acid composition by temperature in mutants of Arabidopsis with alterations in membrane lipid composition. BMC Plant Biology. 4-17.

Gibson, S., V. Arondel, K. Iba, and C. Somerville. 1994. Cloning of a temperature regulated gene encoding a chloroplast w-3 desaturase from Arabidopsis thaliana. Plant Physiol. 106:1615-1621.

Hellergren, J., and P.H. Li. 1981. Survival of Solanum tuberosum suspension cultures to $-14{ }^{\mathrm{C}}$ : The mode of action of proline. Physiol. Plant. 52:449-453.

Herzog, H. 1987a. Freezing resistance and development of faba beans as affected by ambient temperatures, soil moisture and variety. J. Agron. Crop Sci. 159:90100.

Herzog, H. 1987b. A quantitative method to assess freezing resistance in faba beans. J. Agron. Crop Sci. 158:195-204.

Herzog, H. 1989. Influence of pre-hardening duration and dehardening temperatures on varietal freezing resistance in faba beans (Vicia faba L.). Agronomie (Paris). 9:55-61.

Herzog, H., and A. Olszewski. 1998. A rapid method for measuring freezing resistance in crop plants. J. Agron. Crop Sci. 181:71-79.

Hoffmann-Bahnsen, R., and H. Herzog. 2001. Frost resistance-screening in Lupinus albus based on chlorophyll fluorescence measurements: a methodical evaluation and adjustment. 4th European Conference on Grain Legumes. Cracow. Poland. 8-12 july 2001.

Kaup, M.T., C.D. Froese, and J.E. Thompson. 2002. A role for diacylglycerol acyltransferase during leaf senescence. Plant Physiol. 129:1616-1626. 
Koiwai, A., T. Matsuzaki, F. Suzuki, and N. Kawashima. 1981. Changes in total and polar lipids and their fatty acid composition in tobacco leaves during growth and senescence. Plant Cell Physiol. 22:1059-1065.

Kuznetsov, V.V., and N.I. Shevyakova. 1999. Proline under stress: biological role, metabolism, and regulation. Russian J. Plant Physiol. 46:274-287.

Levitt, J. 1980. Responses of Plants to Environmental Stresses. Vol. 1. Academic Press, New York. 166-222.

McKenzie, J.S., R. Paquin, and S.H. Duke. 1988. Cold and Heat Tolerance. In: Alfalfa and Alfalfa Improvement. Hanson, A.A., Barnes, D.K., and Hill, R.R., Jr (eds.). Agronomy monograph No. 29, ASA, WI, pp. 259-302.

Nayyar, H., T.S. Bains, S. Kumar, and G. Kaur. 2005. Chilling effects during seed filling on accumulation of seed reserves and yield of chickpea. J. Sci. Food Agric. 85:1925-1930.

Ohno, R., S. Takumi, and C. Nakamura. 2001. Expression of cold-responsive Lt-Cor gene and development of freezing tolerance during cold acclimation in wheat (Triticum aestivum L.). J. Exp. Bot. 52:2367-2374.

Petcu, E., and M. Terbea. 1995. Proline content and the conductivity test as screening methods for frost tolerance of winter wheat. Bulg. J. Plant Physiol. 21:3-11.

Pollock, C.J. 1986. Fructans and the metabolism of sucrose in vascular plants. New Phytol. 104:1-24.

Rizza, F., C. Crosatti, A.M. Stanca, and L. Cativelli. 1994. Studies for assessing the influence of hardening on cold tolerance of barley genotypes. Euphytica. 75:131-138.

Rosnes, K., O. Junttila, A. Ernstsen, and N. Sandli. 1993. Development of cold tolerance in white clover (Trifolium repens L.) in relation to carbohydrate and free amino acid content. Acta Agriculturae Scandinavica Section B Soil and Plant Science 43:151-155.

Samala, S., J. Yan, and W.V. Baird. 1998. Changes in polar lipid fatty acid composition during cold acclimation in "Midiron" and "U3" bermudagrass. Crop Sci. 38:188-195. 
Samuel, D., R.K.S. Kumar, G. Jayaramoan, P.W. Yang, and C. Yu. 1997. Proline is a protein solubilizing solute. Biochem. Mol. Biol. Int. 41:235-242.

Sanchez, F.J., E.F. de Andres, J.L. Tenorio, and L. Averbe. 2004. Growth of epicotyls, turgor maintenance and osmotic adjustment in pea plants (Pisum sativum L.) subjected to water stress. Field Crops Res. 86:81-90.

Santoiani, C.S., J.A. Tognetti, H.G. Pontis, and G.L. Salerno. 1993. Sucrose and fructan metabolism in wheat roots at chilling temperature. Physiol. Plant. 87:8488.

Shabala, S., O. Babourina, and I. Newman. 2000. Ion-specific mechanisms of osmoregulation in bean mesophyll cells. J. Exp. Bot. 51:1243-1253.

Shaner, G., and R.E. Finney. 1977. The effect of nitrogen fertilization on the expression of slow-mildewing resistance in Knox wheat. Phytopathology. 67:1051-1056.

Steel, R.G.D., and J.H. Torrie. 1981. Principles and Procedures of Statistics. International student edition. McGraw-Hill, New York.

Stoddard, F.L., C. Balko, W. Erskine, H.R. Khan, W. Link, and A. Sarker. 2006. Screening techniques and sources of resistance to abiotic stresses in coolseason food legumes. Euphytica. 147:167-186.

Stone, J.M., J.P Palta, J.B. Bamberg, L.S. Weiss, and J.F. Harbage. 1993. Inheritance of freezing resistance in tuber bearing Solanum species: evidence for independent genetic control of non-acclimated freezing tolerance and cold acclimation capacity. Proc. Natl. Acad. Science USA. 90:7869-7873.

Tantau, H., C. Balko, B. Brettschneider, G. Melz, and K. Dörffling. 2004. Improved frost tolerance and winter survival in winter barley (Hordeum vulgare L.) by in vitro selection of proline over-accumulating lines. Euphytica. 139:19-32.

Taulavuori, K., E. Taulavuori, T. Sarjala, E.M. Savonen, P. Pietiläinen, P. Lähdesmäki, and K. Laine. 2000. In vivo chlorophyll fluorescence is not always a good indicator of cold hardiness. J. Plant Physiol. 157:227-229.

Thies, W. 1971. Schnelle und einfache Analysen der Fettsäure zusammensetzung in einzelnen Raps-Kotyledonen. I. Gaschromatographische und papier chromatographische Methode. Z Pflanzenzüchtung. 65:181-202. 
Thomashow, M.F. 1999. Plant cold acclimation: freezing tolerance genes and regulatory mechanisms. Annu. Rev. Plant Physiol. Plant Mol. Biol. 50:571-599.

Troll, W., and J. Lindsley. 1955. A photometric method for the determination of proline. J. Biol. Chem. 215:655-660.

Utz, H.F. 1991. A computer program for statistical analysis of plant breeding experiments. Institute of Plant Breeding, Seed Science and Population Genetics. University of Hohenheim.

Wei, H., A.L. Dhanaraj, R. Arora, L.J. Rowland, Y. Fu, and L. Sun. 2005. Identification of cold acclimation-responsive Rhododendron genes for lipid metabolism, membrane transport and lignin biosynthesis: importance of moderately abundant ESTs in genomic studies. Plant Cell Environ. 29:558-570.

Xin, Z., and P.H. Li. 1993. Relationship between proline and abscisic acid in the induction of chilling tolerance in maize suspension cultured cells. Plant Physiol. 103:607-613. 


\section{Effect of hardening on frost tolerance and fatty acid composition of leaves and stems of a set of faba bean (Vicia faba L.) genotypes}

Mustapha Arbaoui \& Wolfgang Link (Accepted by Euphytica in an advanced version)

\section{Abstract}

Frost tolerance is a main component of winter-hardiness and improving it would promote faba bean (Vicia faba L.) cropping in cool-temperate regions. In many species, leaf fatty acid composition was found to be related to frost tolerance. The objective of this study was to determine, in a representative sample of genotypes, the effect of hardening on leaf and stem (1) frost tolerance and (2) fatty acid composition, and to seek correlations between them. First leaf, second leaf, and stem of 31 faba bean genotypes were analyzed after hardening and without hardening. High frost tolerance of known winter genotypes and several experimental lines was shown. Hardening had a significant, positive effect on frost tolerance of all three organs. Stems were on average more frost tolerant than leaves. Hardening induced significant changes in the fatty acid composition: oleic acid decreased significantly in leaves by $3.24 \%$ and in stems by $1.77 \%$, while linolenic acid increased in leaves by $6.28 \%$ and in stems by $9.06 \%$. In stems, correlations between frost tolerance and fatty acid composition were not significant. Correlation coefficients strongly indicated that non-hardened oleic acid content, changes in oleic acid and in linoleic plus linolenic acid content in leaves partly explained their frost tolerance $(0.347+<|r|<$ $\left.0.543^{\star *}\right)$. The results corroborate the importance of using genetic differences in the fatty acid metabolism in breeding grain legumes for frost tolerance.

Keywords: Vicia faba, seedlings, hardening, frost tolerance, fatty acid composition.

\section{Introduction}

Faba bean (Vicia faba L.) is an annual grain legume, which is mainly grown for its high protein content (on average 30\%). It is widely used in cereal-dominated rotations as break crop, partly because of its high input of nitrogen in the soil.

Improving frost tolerance is important for many winter crops, because this trait is a main component of winter-hardiness (Rizza et al, 1994; Petcu \& Terbea, 1995; Arbaoui et al., 2007). Winter-hardiness is the ability of plants to resist environmental stress during the winter. These include biotic stress such as snow mould and abiotic stress such as freezing temperatures, adverse soil composition and saturation of 
soils with water (Davidson \& Reid, 1987; Herzog, 1987a; Badaruddin \& Meyer, 2001). In cool-temperature climates, faba bean is mainly grown as a spring crop. The insufficient winter-hardiness of the current autumn-sown cultivars is the main limiting factor. Recent studies showed superiority of autumn-sown winter beans for grain yield and protein yield when compared to spring beans. Breeding for frost tolerance would increase the interest of growing faba bean in these climates.

Several methods have been used to assess frost tolerance: visual scoring of freezing injuries in leaves (Herzog, 1987b; Herzog, 1989; Rizza et al., 1994; Duc \& PetitJean, 1995; Badaruddin \& Meyer, 2001; Arbaoui et al., 2007), measuring regrowth or leaf conductivity (Herzog, 1987b), and evaluating chlorophyll fluorescence (Herzog \& Olszewski, 1998; Taulavuori et al., 2000; Hoffmann-Bahnsen \& Herzog, 2001). These methods have been mainly applied because they are non-destructive, and they were applied to leaves because leaves are directly exposed to freezing and low nonfreezing temperatures. Although visual scoring of freezing injuries may not be perfectly impartial, it was shown to be as reliable as measurement of conductivity (Herzog, 1987b) and measurement of chlorophyll content (Herzog \& Olszewski, 1998).

Hardening, also known as cold acclimation is a process triggered by an exposure to low non-freezing temperatures. In agricultural conditions, hardening occurs seasonally when seedlings are exposed to those temperatures before the onset of winter. Hardening conditions, especially duration, influence the frost tolerance that is ultimately reached. Several studies proved lower lethal freezing temperatures of hardened seedlings in comparison to unhardened seedlings (Herzog, 1987b; Rizza et al., 1994; Petcu \& Terbea, 1995; Badaruddin \& Meyer, 2001; Arbaoui et al., 2007). Herzog (1989) showed that faba bean seedlings should be kept at least 10 days at low non-freezing temperatures to reach their maximum level of frost tolerance.

Hardening induces physiological and biochemical changes in plant tissues. The main changes observed were (1) accumulation of sucrose and fructans (Pollock, 1986; Santoiani et al., 1993), (2) increase of total protein concentration (Davis \& Gilbert; 1970; McKenzie et al., 1988), (3) accumulation of free proline (Petcu \& Terbea, 1995; Dörffling et al., 1997; Thomashow, 1999), (4) increase of cell membrane stability (Chandrasekar et al., 2000), (5) increased content of phospholipid and 
polyunsaturated fatty acid (linoleic and linolenic acids) in cell membranes, and (6) increase of desaturase enzyme activity (Cyril et al., 2002; Wei et al., 2006).

The major classes of lipids present in plant cell membranes are the phospholipids and glycolipids (Lea \& Leegood, 1993). In young growing leaves, these two classes represent more than $75 \%$ of the total lipid content in cells (Koiwai et al., 1981; Kaup et al., 2002). Their corresponding fatty acids may be either saturated or unsaturated. In the chloroplast envelope of Vicia faba, linolenic acid content across galactolipids and phospholipids corresponded to $58 \%$ of the total fatty acid content (Mackender \& Leech, 1974). The content and increase of long chains of polyunsaturated fatty acids were observed to maintain membrane fluidity by introducing bends or kinks in the fatty acids chains, thereby inhibiting tight packing of adjacent lipid molecules (Lehninger, 1977; Vigh et al., 1998) and increasing the frost tolerance (Cyril et al., 2002).

In most studies, this relationship was tested in a very limited number of genotypes that were extremely different for their frost tolerance. Synthesis of the polyunsaturated fatty acids is due to desaturase enzyme activity. Under low nonfreezing temperatures, over-expression of desaturase enzymes was observed (Gibson et al., 1994).

The objectives of this study were (1) to investigate in a representative sample of frost tolerant and frost susceptible genotypes whether exposure of faba bean seedlings to low non-freezing temperatures has a consistent effect on fatty acid saturation levels in first leaves, second leaves, and stems, (2) to assess frost tolerance of these three organs after hardening and non-hardening, and (3) to seek genetic correlations between fatty acid composition and frost tolerance for the three organs.

\section{Materials and methods}

Plant material

A representative set of faba bean (Vicia faba L.) encompassing 12 European winter genotypes, 12 experimental lines, and seven checks (including three spring genotypes) was used (Table 1). The European genotypes were selected due to their current importance in breeding, reasonable winter-hardiness and good yield performance. The experimental lines resulted from crosses between BPL 4628 ("Bean Pure Line", Chinese inbred line from the ICARDA germplasm collection), 
Scirocco (Sci, German spring inbred line) and Côte d'Or/1 (inbred line derived from the winter-hardy French landrace Côte d'Or).

Two traits were measured on hardened and unhardened seedlings in this set of material: frost tolerance and fatty acid composition. For both traits, during germination and emergence, the temperature was kept at $10^{\circ} \mathrm{C}$ days $/ 3^{\circ} \mathrm{C}$ nights for 14 days to produce hardened seedlings, and at $18^{\circ} \mathrm{C}$ days $/ 1^{\circ} \mathrm{C}$ nights for 10 days to produce unhardened seedlings. For every genotype, four seedlings were grown in a pot $\left(17 \times 17 \times 17 \mathrm{~cm}^{3}\right)$ filled with $5 \mathrm{~kg}$ of soil (1:1 mixture of sand and compost). The soil was kept between $70 \%$ and $80 \%$ of its saturation level.

Artificial frost

These experiments were designed for detailed assessment of frost tolerance of faba bean seedlings. The experiments were conducted in a plant growth chamber $(2 \times 2 \times 2$ $\mathrm{m}^{3}$ ), which can produce freezing temperatures. When the seedlings reached two expanded leaves, all pots were transferred to (i.e. loaded to) the frost chamber. One of such transfer was called a load. Before testing, hardened seedlings were further exposed to temperature of $2.5^{\circ} \mathrm{C}$ days $/ 0^{\circ} \mathrm{C}$ nights $\mathrm{d}$ uring one week for further hardening. Light in the frost chamber was programmed at $200 \mu \mathrm{mol} \mathrm{s} \mathrm{m}^{-1}$ during 12 hours. The air humidity was freely fluctuating between $80 \%$ and $90 \%$ according to temperature fluctuation. In both treatments, genotypes were randomised in three loads, with three replicates per load, and frost tolerance was assessed for each of the four plants of the replicate.

The test included six steps of decreasing freezing air temperatures during "night" and thawing during the artificial "day" (Figure 1).

After each step, and after ten hours of thawing, first leaf, second leaf, and stem were individually and visually scored on every seedling (Herzog 1987b; Duc \& PetitJean, 1995) for colour ( 1 = green, 4 = black), and turgidity ( 1 = fully turgid, $4=$ not turgid). Six traits were scored: first leaf colour (FLC), second leaf colour (SLC), stem colour (StC), first leaf turgidity (FLT), second leaf turgidity (SLT), and stem turgidity (StT). For each trait, injury scores resulting from every step were combined as follows. For each step, the product of actual freezing temperature $\left({ }^{\circ} \mathrm{C}\right)$ and duration of freezing temperature under minus $6^{\circ} \mathrm{C}$ (hours) was calculated to determine the number of degree-hours $\left({ }^{\circ} \mathrm{C} h\right)$. Finally, the injury score at e ach freezing step was multiplied 
with its corresponding number of degree-hours and added across the six steps to produce the "Area Under Symptom Progress Curve" (AUSPC; corresponding to the "Area Under Disease Progress Curve", AUDPC; Shaner \& Finney, 1977), which thus quantified frost susceptibility. The AUSPC of the first leaf, the second leaf and the stem of each genotype in each treatment was used to calculate the mean AUSPC across seedlings, replicates, and loads.

\section{Fatty acids}

First leaves, second leaves, and stems of hardened and unhardened seedlings were analyzed for their total fatty acid composition. This material was especially grown for this purpose and not used for assessing frost tolerance. The set of material was tested in two experiments with two replicates per experiment in both treatments. Only two out of four seedlings per pot were used as one replicate. When seedlings were two fully expanded leaves, shoots were cut, dried at $50^{\circ} \mathrm{C}$ for 48 hours, and ground to a fine powder. Total tissue lipid extraction followed the experimental protocol of Thies (1971) with slight modifications in order to avoid oxidation of polyunsaturated fatty acids. Fatty acids were analyzed by gas chromatography (Perkin Elmer 8600). Three-microliter samples were manually injected into column (Permabond FFAP-0.25 $\mu \mathrm{m}, 25 \mathrm{~m} \times 0.25 \mathrm{~mm}$ ). The column temperature was $215^{\circ} \mathrm{C}$, injector temperature $280^{\circ} \mathrm{C}$ and detector temperature $280^{\circ} \mathrm{C}$. The carrier $\mathrm{g}$ as was hydrogen at a pressure of $100 \mathrm{kPa}$. The individual peaks were identified based on comparisons to a standard sample. The quantity of each fatty acid was expressed as percentage of the total fatty acid composition.

Statistics

Analysis of variance was performed to determine whether genotypes and organs were significantly different, and whether hardening induced changes in the frost tolerance and the total fatty acid composition using Plabstat (Utz, 1991).

In case of significant differences between genotypes, LSD test $(5 \%)$ was performed to determine distinct groups of genotypes (Steel \& Torrie, 1981). The heritability of the genotypes' results was also determined $\left(h^{2}=\right.$ genotypic variance / phenotypic variance). 
In order to test for a useful relationship between (1) content and changes in fatty acid composition and (2) frost tolerance, correlation analyses were performed between these two traits. Instead of the usual Pearson correlation coefficient, the Spearman rank correlation coefficient was used. The purpose was to avoid an inflating effect from group mean differences between winter and spring genotypes (Steel \& Torrie, 1981).

\section{Results and Discussion}

Artificial frost

Exposure to low non-freezing temperatures (hardening) significantly increased frost tolerance of all genotypes. Already after the first step of frost $\left(-8^{\circ} \mathrm{C}\right)$, the mean score of unhardened seedlings was 2.16 , and became 3.87 after the fifth step $\left(-19^{\circ} \mathrm{C}\right)$. The mean score of hardened seedlings after the first step was 1.01 and was only 2.26 after the fifth step. Thus, the mean AUSPC of hardened seedlings (1097 scoreunit ${ }^{\circ} \mathrm{C}$ h) was much lower than the mean AUSPC of unhardened seedlings (2245 scoreunit 'C h).

Analysis of variance showed significant differences between genotypes. For hardened seedlings, the superior group included seven genotypes. Two of them were European genotypes: Karl and GöttWAB and five were experimental lines: F7 (Côte d'Or/1 x BPL 4628)-95, F7-89, F7-29, F7-49, and F4 (Scirocco x Côte d'Or/1)-3028-2. Among the unhardened seedlings F7 (Côte d'Or/1 x BPL 4628)-95 was the most frost tolerant and significantly different from all other genotypes. The significant and marked interaction between genotypes and treatments were mainly caused by a stronger effect (on average 100 scoreunit $^{\circ} \mathrm{C} h$ ) of hardening shown by the more frost tolerant entries when compared to the less frost tolerant entries. Across the three organs, different genotypes were identified in the superior group for frost tolerance after hardening and non-hardening.

On average, and in both treatments, stems were more frost tolerant than the two leaves (AUSPC, $1057<1117$ after hardening; $2182<2277$ after non-hardening). The second leaf was on average more frost tolerant than the first leaf after hardening, whereas both unhardened leaves showed very similar AUSPC. Thus, in the case of hardened seedlings, the results corroborated Herzog (1989) findings of a higher frost tolerance of the younger hardened leaves compared to older ones. In this 
experiment, despite empirical differences observed among first leaf, second leaf, and stem, differences among organs were not significant due to the large variation of the differences between organs across loads (source of variation $\mathrm{O} x \mathrm{~L} / \mathrm{T}$; Table 2).

The results of the genotypes in this experiment were highly repeatable $\left(h^{2}=0.887\right)$. Thus, the best genotypes identified for mean frost tolerance across organs and treatments could efficiently be selected for further breeding research. Although the organ $x$ genotype interactions was significant, the high correlation among the three organs $\left(0.833^{* *}<r<0.953^{* *}\right.$ after hardening; $0.694^{* *}<r<0.981^{* *}$ after nonhardening) would allow pre-selection of superior genotypes on the basis of one organ type in both treatments.

Fatty acids

Among the ten fatty acids identified, six were further analyzed because they represented more than $95 \%$ of the total composition. Those fatty acids were: palmitic acid (16:0), stearic acid (18:0), oleic acid (18:1), linoleic acid (18:2), linolenic acid (18:3), and stearidonic acid (18:4). The main fatty acid in leaves and stems was 18:3 (Table 3).

The three organs were significantly different for all fatty acids, except for 18:1 (Table 4). Taking only the two leaves as organ factor, no significant differences between first and second leaf were observed for all fatty acids across treatments (details not shown).

The only fatty acid significantly affected by the treatments was 18:1 (Table 4), which decreased in leaves and stems following hardening. For 18:3, treatment was not significant. Nevertheless, its $F$-value $(F=6.96)$ was large so the non significance may be due to the low number of degrees of freedom of the experimental factor (DF $=2$ ). Content of 18:3 increased after hardening in both leaves of all 30 genotypes, and in stems of 29 out of 30 genotypes. Cyril et al. (2002) found similarly that hardening decreased 18:1 content and increased 18:3 content in Paspalum leaves. Hardening induced a non-significant decrease of 18:2 content in leaves of all genotypes and in stems of 27 genotypes. Genotypes were significantly different for their fatty acid composition, and the genotype $\mathrm{x}$ organ $\mathrm{x}$ treatment terms were highly significant (Table 4) for 18:1, 18:2, and 18:3 content. Although hardening had no 
significant effect on 18:2 and 18:3 content, it had a significant modulating effect on G $x O$ across all genotypes for $18: 1$ content, as well as for $18: 2$ and 18:3 content.

Changes in 18:3 content were significantly correlated with changes in 18:1 content for the first leaf $\left(r=-0.559^{* *}\right)$ and the second leaf $\left(r=-0.641^{* *}\right.$; Figure 2$)$, but not for the stem $(r=-0.265)$. On the other hand, in the stem the changes in 18:3 content were significantly correlated with changes in 18:2 $\left(r=-0.905^{* *}\right)$. Thus, hardening induced the synthesis of additional 18:3, obviously mainly from 18:1 in leaves and 18:2 in stem. Desaturase enzyme activity during hardening is probably the cause of 18:3 increase, especially in the cytoplasmic membranes. In several plant species, molecular studies have indicated over-expression of desaturase genes during hardening (Gibson et al., 1994; Ohno et al., 2001). The size of the changes in 18:1, 18:2 and 18:3 were different in the different organs (Table 3). In both leaves, the hardening decreased $18: 1$ content on average by $7.25 \%-4.01 \%=3.24 \%$ and $18: 2$ content by $1.70 \%$ while increasing $18: 3$ content by $6.28 \%$. In the stem, hardening decreased $18: 1$ content by only $1.77 \%, 18: 2$ by $4.73 \%$, and increased $18: 3$ content by $9.06 \%$. Thus, accumulation of the polyunsaturated acid (18:3) was higher in stem than in leaves. A higher accumulation of 18:3 was recorded in the second leaf than in the first leaf. Hence, higher desaturase enzymes activities may be observed in stems than in leaves. Nevertheless, this hypothesis should be tested by further analyses on enzyme activities in the three organs. In the first leaf and the second leaf, the highest increase of 18:3 due to hardening was observed in BPL (8.66\%), and the lowest in Mythos (spring bean; 1.54\%). In stem, Pistache (spring bean; 22.94\%) had the highest increase, whereas Webo/1 showed a decrease (2.58\%).

\section{Correlation analyses}

The unhardened 18:1 content in the first leaf $\left(r=-0.376^{*}\right)$ and second leaf $(r=-$ $\left.0.536^{* *}\right)$, the unhardened 18:2+18:3 content in the first leaf $(r=0.340+)$ and second leaf $\left(r=0.382^{*}\right)$ were significantly correlated with their corresponding frost tolerance (unhardened AUSPC); whereas 18:2 and 18:3 content in both treatments were not (Table 5). Moreover, the higher the initial (non-hardened) content in 18:1 in leaves was, the lower was their AUSPC. Indeed, with the given correlation between the decrease of 18:1 and increase of 18:2+18:3 content due to hardening $\left(r=-0.730^{* *}\right)$, high initial content of 18:1 would lead to high increase of polyunsaturated fatty acids. Actually, the changes observed in 18:2+18:3 and 18:1 content were significantly 
correlated with the frost tolerance with and without hardening in both leaves (Table 5). Taken as pattern, these correlations propose that genetic variation in leaf frost tolerance is a combined result of (1) variation of unhardened frost tolerance which partly depends on the variation of the initial 18:1 content, and a result of (2) the variation of hardening response shown by the changes in 18:1 and 18:2+18:3 content.

Moreover, changes in fatty acid composition of both leaves (especially the youngest one) were developing partly in parallel to the genotypes frost tolerance gradient. In breeding programs, changes in the leaf fatty acid composition due to hardening could be used in indirect pre-selection for frost tolerance. On the other hand, fatty acid composition and its changes in stems due to hardening could not be used because of the low correlation coefficients.

The comparison among the three organs for their frost tolerance and fatty acid composition showed that stem had the highest frost tolerance and the highest increase of polyunsaturated fatty acids, followed by the second leaf, and then by the first leaf. Apparently, there was higher frost tolerance gene expression in stems than in leaves.

This finding should be helpful in the studies aiming to identify the main alleles associated with faba bean frost tolerance variation and with the process of hardening. Since fatty acid composition was found to be related to frost tolerance, genes encoding for fatty acid composition and desaturation are among the very good candidates for frost tolerance genes.

\section{Acknowledgements}

This work was supported by funds from the commission of the European Communities, specific Research Program Quality of Life and Management of Living Resources, QLK5-2001-02307, acronym "Eufaba". It does not necessarily reflect its views and in no way anticipates the Commissions' future policy in this area. The authors thank NPZ-Lembke Company for their financial contribution and Prof. Fred Stoddard for his very valuable hints. 
Table II-1. Faba bean germplasm used in experiments on frost tolerance, comprising 12 European winter cultivars and derived lines, 12 experimental lines and seven checks.

\begin{tabular}{|c|c|c|}
\hline Cultivars and lines & Experimental inbred lines & Check cultivars and lines \\
\hline Silver & F7 (Côte d'Or/1 x BPL 4628)-29 & Pistache (spring type) \\
\hline Target & F7 (Côte d'Or/1 x BPL 4628)-66 & Merkur (spring type) \\
\hline Karl & F7 (Côte d'Or/1 x BPL 4628)-95 & Mythos (spring type) \\
\hline GöttWAB & F7 (Côte d'Or/1 x BPL 4628)-5 & Winter bean population \\
\hline Punch & F7 (Côte d'Or/1 x BPL 4628)-50 & Hiverna \\
\hline Striker & F7 (Côte d'Or/1 x BPL 4628)-89 & Côte d'Or/1 il \\
\hline Clipper & F7 (Côte d'Or/1 x BPL 4628)-49 & BPL 4628 (ICARDA Bean Pure \\
\hline Irena & F4 (Scirocco x Côte d'Or/1)-3028-1 & Line) \\
\hline Diva & F4 (Scirocco x Côte d'Or/1)-3028-2 & \\
\hline Bulldog/ $1^{\text {il }}$ & F4 (Scirocco x Côte d'Or/1)-3028-3 & \\
\hline Hiverna/2 il & F4 (Scirocco x Côte d'Or/1)-3029-1 & \\
\hline Webo/1 il & F4 (Scirocco x Côte d'Or/1)-3033-1 & \\
\hline
\end{tabular}

Table II-2. Analysis of variance of frost tolerance (AUSPC, area under symptom progress curve).

\begin{tabular}{|c|c|c|c|}
\hline Sources of variation & DF & MS $\left(x 10^{4}\right)$ & F-value \\
\hline Treatments & 1 & 55206.82 & $163.16^{\star \star}$ \\
\hline Loads / Treatments & 4 & 338.36 & $17.14^{\star *}$ \\
\hline Replicates / L x T & 12 & 19.74 & $45.12^{* *}$ \\
\hline Genotypes & 30 & 65.70 & $8.92^{* *}$ \\
\hline Genotype x Treatments & 30 & 15.52 & $2.11^{\star *}$ \\
\hline $\mathrm{G} \times \mathrm{L} / \mathrm{T}$ & 120 & 7.37 & $2.28^{* *}$ \\
\hline$R \times G / L \times T$ & 360 & 3.23 & $7.37^{\star *}$ \\
\hline Organs & 2 & 127.84 & 2.72 \\
\hline Organs x Genotypes & 60 & 4.51 & $4.27^{\star \star}$ \\
\hline Organs $\mathrm{x}$ Treatments & 2 & 25.50 & 0.54 \\
\hline $\mathrm{O} \times \mathrm{G} \times \mathrm{T}$ & 60 & 2.26 & $2.14^{\star \star}$ \\
\hline $\mathrm{O} \times \mathrm{L} / \mathrm{T}$ & 8 & 46.92 & $107.23^{* *}$ \\
\hline$O \times G \times L / T$ & 240 & 1.06 & $2.41^{* *}$ \\
\hline Error & 744 & 0.44 & \\
\hline Heritability of $\mathrm{G}$ & 0.887 & & \\
\hline
\end{tabular}

Table II-3. Mean fatty acid composition (\%) across genotypes of the first leaf, the second leaf, and the stem after hardening and without hardening.

\begin{tabular}{lccc|ccc}
\hline Treatment & \multicolumn{3}{c|}{ Hardened } & \multicolumn{3}{c}{ Unhardened } \\
\hline Organ & First leaf & Second leaf & Stem & First leaf & Second leaf & Stem \\
\hline $16: 0$ & 9.72 & 9.82 & 13.29 & 10.27 & 10.89 & 14.38 \\
$18: 0$ & 1.20 & 1.17 & 1.58 & 1.24 & 1.27 & 1.79 \\
$18: 1$ & 4.12 & 3.90 & 4.62 & 7.23 & 7.26 & 6.39 \\
$18: 2$ & 18.07 & 18.08 & 31.39 & 19.10 & 20.45 & 36.12 \\
$18: 3$ & 56.89 & 57.34 & 41.47 & 51.29 & 50.38 & 32.41 \\
$18: 4$ & 5.76 & 5.68 & 2.97 & 6.95 & 6.27 & 3.43 \\
\hline
\end{tabular}


Table II-4. Analysis of variance for fatty acid composition (\%). F-values

\begin{tabular}{|c|c|c|c|c|c|c|c|}
\hline Sources of variation & $\mathrm{DF}$ & $16: 0$ & $18: 0$ & $18: 1$ & $18: 2$ & $18: 3$ & $18: 4$ \\
\hline Treatments & 1 & 0.75 & 0.55 & $210.25^{\star \star}$ & 1.20 & 6.96 & 1.07 \\
\hline $\mathrm{E} / \mathrm{T}$ & 2 & $10.48^{*}$ & 3.54 & 0.28 & $90.80^{\star *}$ & $15.44^{*}$ & $7.17^{*}$ \\
\hline Replicates / E x T & 4 & $21.97^{* *}$ & $8.29^{* *}$ & $31.81^{* *}$ & $2.71^{*}$ & $16.12^{\star *}$ & $42.77^{\star *}$ \\
\hline Genotypes & 29 & $3.04^{* *}$ & $2.11^{* *}$ & $5.86^{* *}$ & 1.49 & $1.87^{*}$ & $3.24^{\star *}$ \\
\hline $\mathrm{G} \times \mathrm{T}$ & 29 & 0.72 & 1.29 & $2.16^{\star \star}$ & 1.45 & 1.36 & 1.03 \\
\hline $\mathrm{G} \times \mathrm{E} / \mathrm{T}$ & 58 & $3.57^{* *}$ & $2.03^{* *}$ & $3.56^{\star *}$ & $6.08^{\star *}$ & $4.50^{* *}$ & $2.95^{\star *}$ \\
\hline$R \times G / E \times T$ & 116 & $1.63^{\star *}$ & $1.86^{\star *}$ & $1.60^{* *}$ & 0.95 & $1.40^{*}$ & $1.65^{\star *}$ \\
\hline Organs & 2 & $133.73^{\star \star}$ & $63.79^{\star *}$ & 0.09 & $114.45^{\star \star}$ & $78.48^{\star *}$ & $95.67^{\star *}$ \\
\hline$O \times G$ & 58 & $1.56^{*}$ & $1.95^{\star *}$ & $2.36^{\star \star}$ & $1.68^{\star \star}$ & $2.79^{* *}$ & $1.56^{*}$ \\
\hline $\mathrm{O} \times \mathrm{T}$ & 2 & 0.96 & 3.76 & $9.18^{*}$ & 1.73 & 0.58 & 1.63 \\
\hline $\mathrm{O} \times \mathrm{G} \times \mathrm{T}$ & 58 & 0.65 & 1.01 & $1.61^{*}$ & $1.59^{*}$ & $1.58^{*}$ & 1.14 \\
\hline $\mathrm{O} \times \mathrm{E} / \mathrm{T}$ & 4 & $13.09^{* *}$ & 5.50 ** & $8.92^{* *}$ & $46.69^{\star *}$ & $52.89^{* *}$ & $16.67^{\star \star}$ \\
\hline $\mathrm{O} \times \mathrm{G} \times \mathrm{E} / \mathrm{T}$ & 116 & $2.75^{\star \star}$ & $1.43^{*}$ & $2.23^{\star \star}$ & $3.36^{\star *}$ & $2.61^{\star \star}$ & $2.07^{\star \star}$ \\
\hline Error & 240 & & & & & & \\
\hline Heritability of $\mathrm{G}$ & & 0.671 & 0.527 & 0.829 & 0.329 & 0.464 & 0.691 \\
\hline
\end{tabular}

${ }^{*},{ }^{* *}$, significant at the 0.05 and 0.01 level of the probability, respectively. 
Table II-5. Spearman rank correlation coefficient between frost tolerance after hardening and without hardening with 18:1, 18:2, 18:3, and 18:2+18:3 fatty acid content after hardening, without hardening, and their changes due to hardening in the first leaf, the second leaf and the stem

\begin{tabular}{|c|c|c|c|c|}
\hline Fatty acids & Organ & & Hardened AUSPC & Unhardened AUSPC \\
\hline \multirow{9}{*}{$\underset{\infty}{\infty}$} & \multirow{3}{*}{ Leaf 1} & Hardened & ns & $\mathrm{ns}$ \\
\hline & & Non-hardened & $-0.376^{\star}$ & $-0.356+$ \\
\hline & & Change due to hardening & $0.427^{*}$ & $0.511^{* *}$ \\
\hline & \multirow{3}{*}{ Leaf 2} & Hardened & ns & ns \\
\hline & & Non-hardened & $-0.536^{\star *}$ & $-0.466^{\star *}$ \\
\hline & & Change due to hardening & $0.543^{* *}$ & $0.490^{* *}$ \\
\hline & \multirow{3}{*}{ Stem } & Hardened & ns & ns \\
\hline & & Non-hardened & ns & ns \\
\hline & & Change due to hardening & ns & ns \\
\hline \multirow{9}{*}{$\begin{array}{l}\stackrel{N}{\infty} \\
\stackrel{\infty}{ }\end{array}$} & \multirow{3}{*}{ Leaf 1} & Hardened & ns & ns \\
\hline & & Non-hardened & ns & ns \\
\hline & & Change due to hardening & ns & ns \\
\hline & \multirow{3}{*}{ Leaf 2} & Hardened & ns & ns \\
\hline & & Non-hardened & ns & ns \\
\hline & & Change due to hardening & $-0.314+$ & ns \\
\hline & \multirow{3}{*}{ Stem } & Hardened & ns & ns \\
\hline & & Non-hardened & ns & ns \\
\hline & & Change due to hardening & ns & ns \\
\hline \multirow{9}{*}{$\begin{array}{l}\infty \\
\infty \\
\infty\end{array}$} & \multirow{3}{*}{ Leaf 1} & Hardened & ns & ns \\
\hline & & Non-hardened & ns & ns \\
\hline & & Change due to hardening & ns & ns \\
\hline & \multirow{3}{*}{ Leaf 2} & Hardened & ns & ns \\
\hline & & Non-hardened & ns & ns \\
\hline & & Change due to hardening & ns & ns \\
\hline & \multirow{3}{*}{ Stem } & Hardened & ns & ns \\
\hline & & Non-hardened & ns & ns \\
\hline & & Change due to hardening & ns & ns \\
\hline \multirow{9}{*}{ 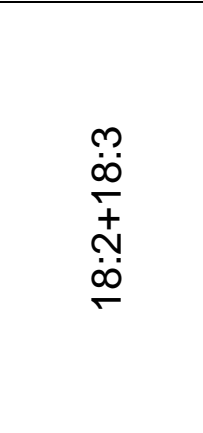 } & \multirow{3}{*}{ Leaf 1} & Hardened & ns & ns \\
\hline & & Non-hardened & ns & $0.340+$ \\
\hline & & Change due to hardening & $-0.347+$ & $-0.392^{*}$ \\
\hline & \multirow{3}{*}{ Leaf 2} & Hardened & $\mathrm{ns}$ & ns \\
\hline & & Non-hardened & ns & $0.382^{*}$ \\
\hline & & Change due to hardening & $-0.490^{\star *}$ & $-0.518^{\star *}$ \\
\hline & \multirow{3}{*}{ Stem } & Hardened & ns & ns \\
\hline & & Non-hardened & ns & ns \\
\hline & & Change due to hardening & ns & $-0.349+$ \\
\hline
\end{tabular}

ns, non-significant Spearman's rank correlation coefficient.

$+,{ }^{*},{ }^{* *}$, significant at the $0.10,0.05$, and 0.01 level of the probability, respectively. 


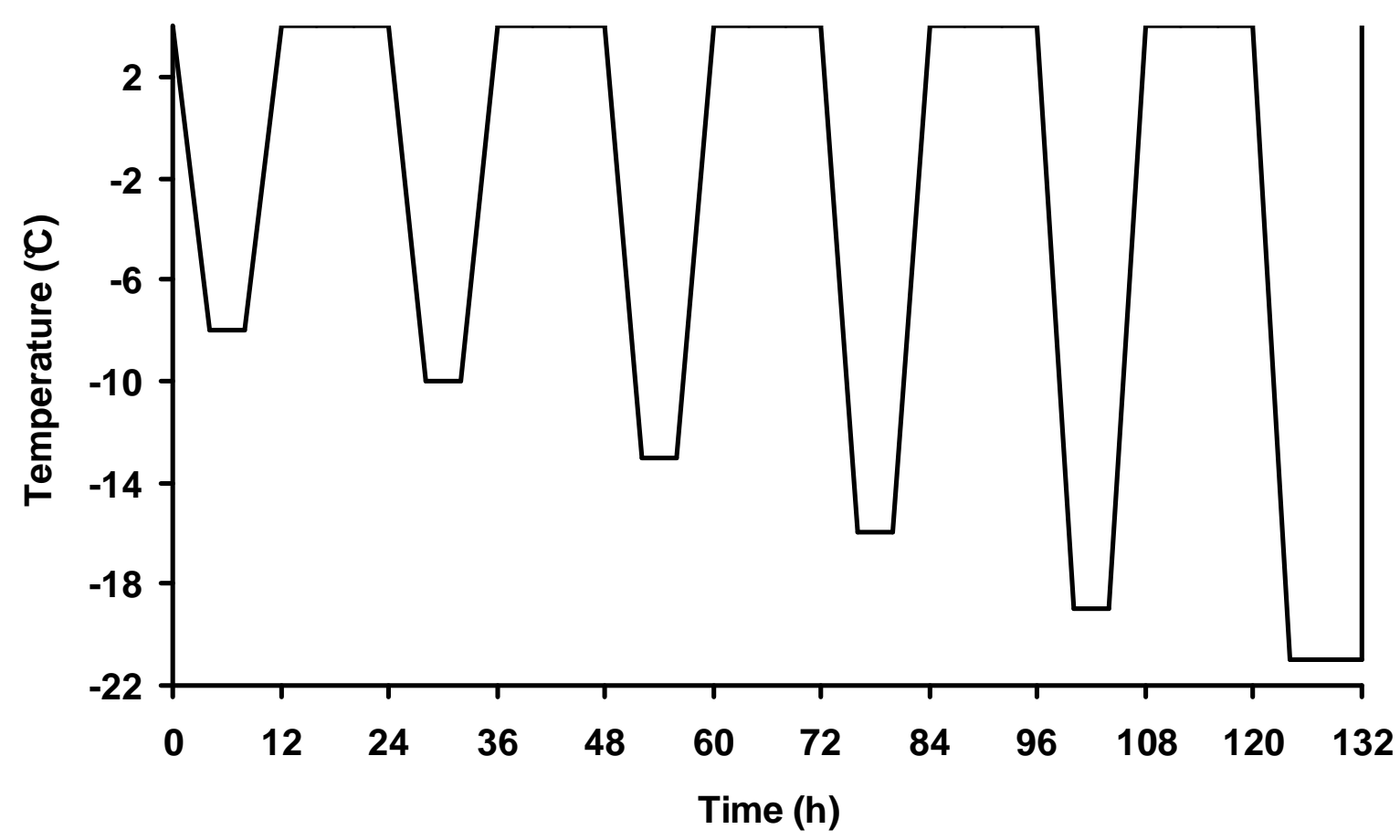

Figure II-1. Temperature profile of the artificial frost test. 


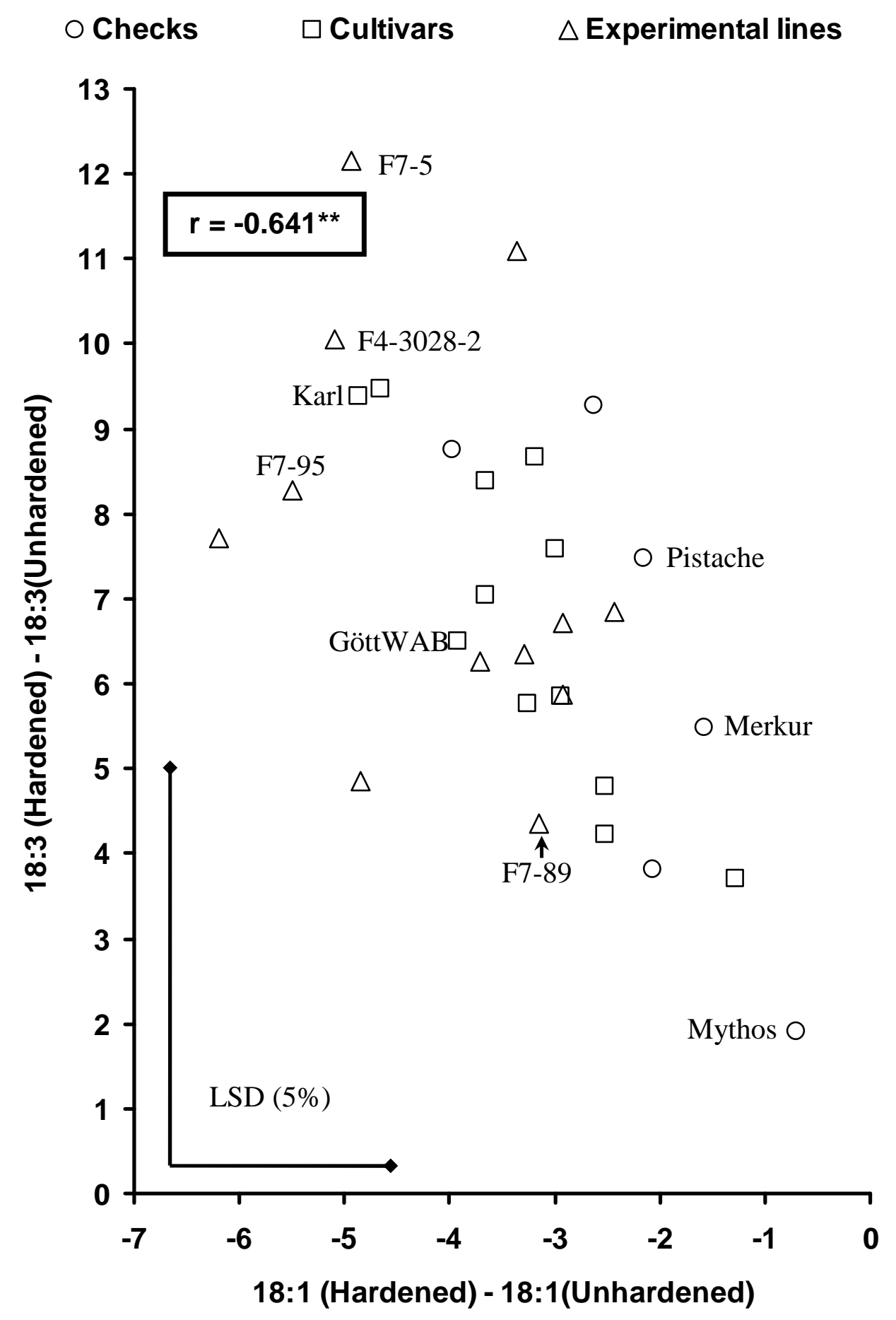

Figure II-2. Changes in oleic acid (18:1) and linolenic acid (18:3) content due to hardening in the second leaf. 


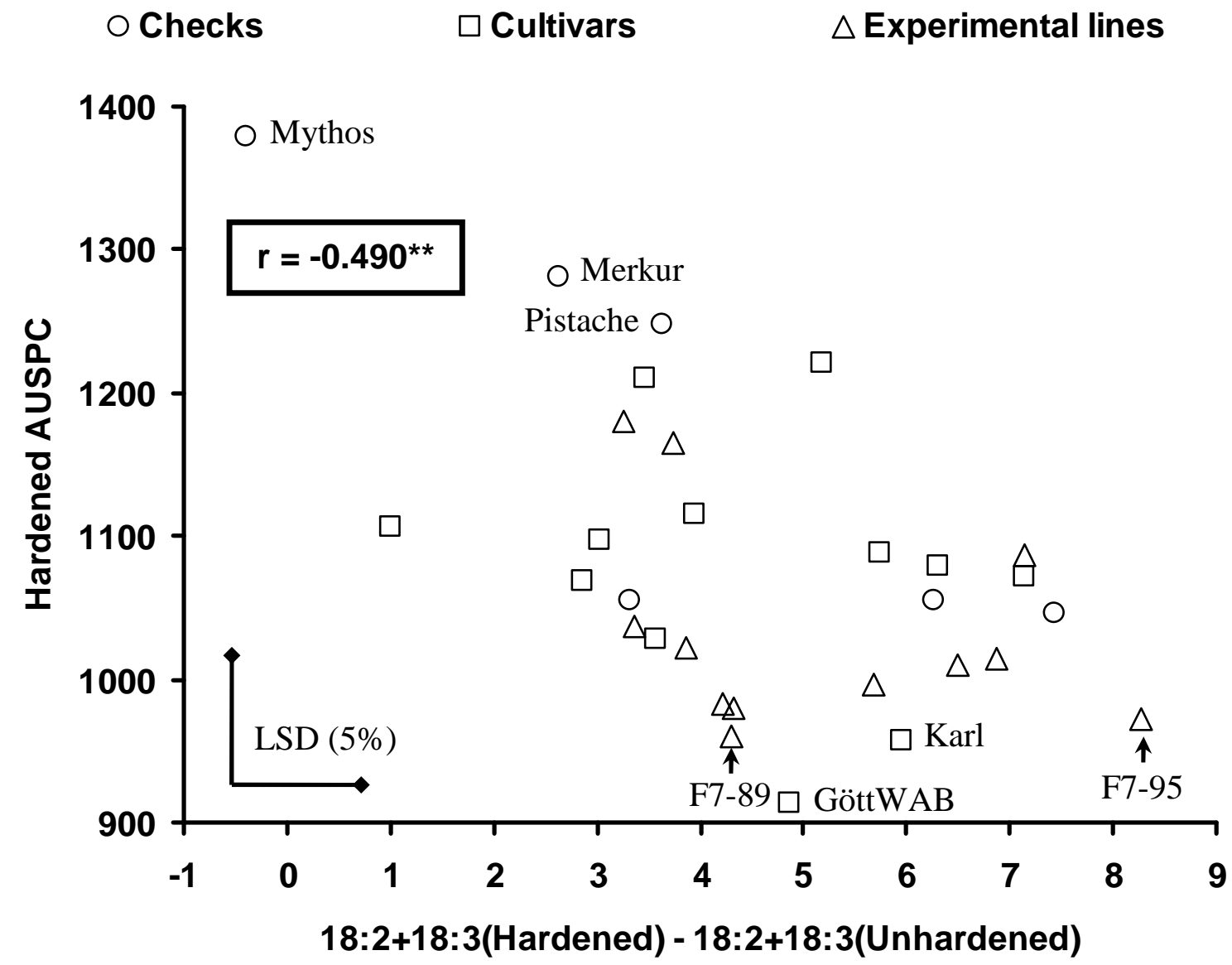

Figure II-3a. Changes in 18:2+18:3 content due to hardening and frost tolerance (area under symptom progress curve) of hardened plants. Data from the second leaf. 
O Checks

Cultivars

$\triangle$ Experimental lines

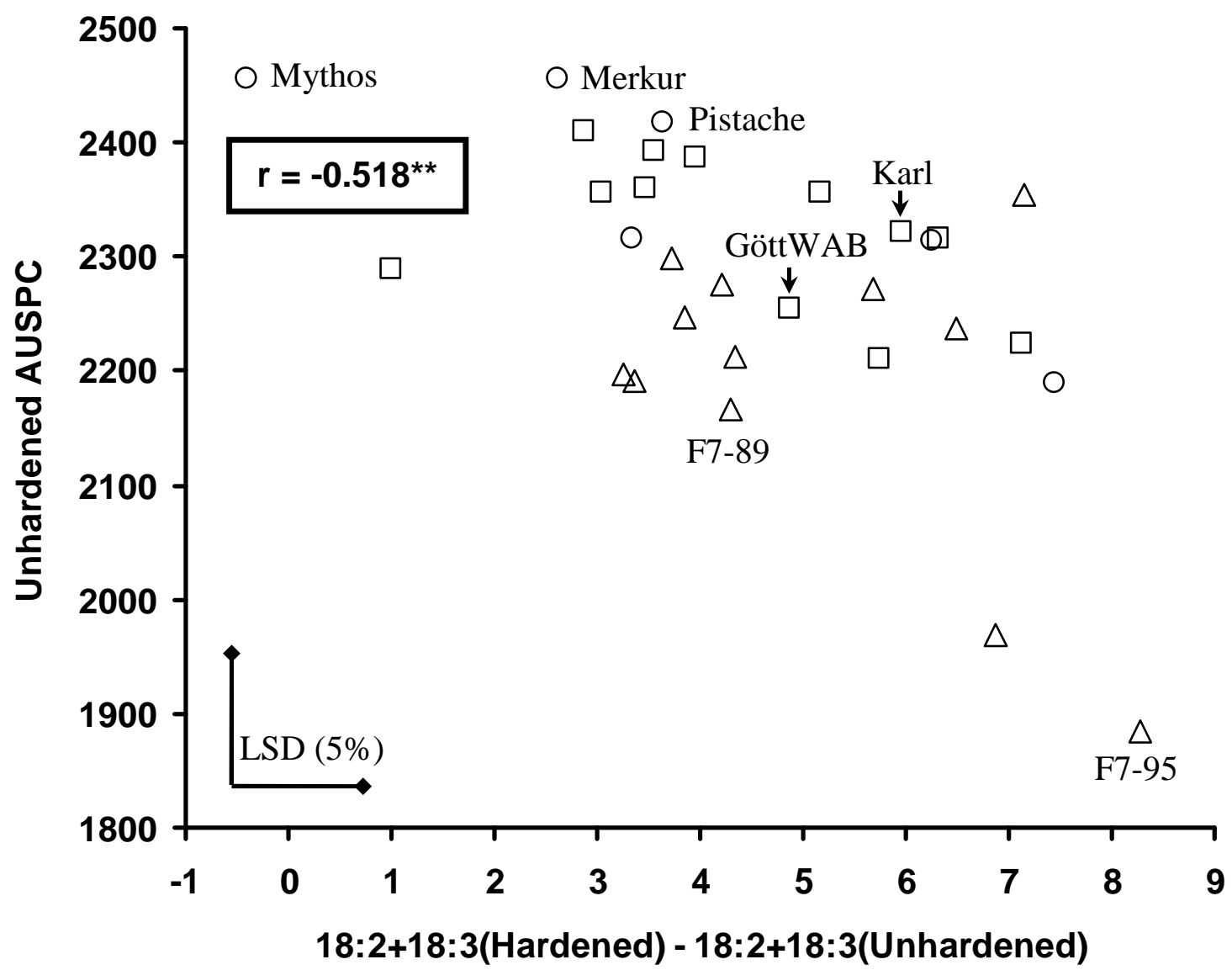

Figure II-3b. Changes in 18:2+18:3 content due to hardening and frost tolerance (area under symptom progress curve) of non-hardened plants. Data from the second leaf.

\section{References}

Arbaoui M, Balko C, Link W (2007) Study of faba bean (Vicia faba L.) winterhardiness and development of screening methods for frost tolerance. (Submitted to Crop Sci).

Badaruddin M, Meyer DW (2001) Factors modifying frost tolerance of legume species. Crop Sci 41:1911-1916.

Chandrasekar V., Sairam RK, Srivastava GC (2000) Physiological and biochemical responses of hexaploid and tetraploid wheat to drought stress. J Agron Crop Sci 185:219-227. 
Cyril J, Powell GL, Duncan RR, Baird WV (2002) Changes in membrane polar lipid fatty acids of seashore Paspalum in response to low temperature exposure. Crop Sci 42:2031-2037.

Davidson NJ, Reid JB (1987) The influence of hardening and waterlogging on the frost resistance of subalpine eucalypts. Aust J Bot 35:91-101.

Davis DL, Gilbert WB (1970) Winter hardiness and changes in soluble protein fractions of bermudagrass. Crop Sci 10:7-9.

Duc G, PetitJean F (1995) Study of inheritance of freezing tolerance in Vicia faba L. 2nd European Conference on Grain Legumes. Copenhagen. Denmark. 11-15 July 1995.

Dörffling K, Dörffling H, Lesselich G, Luck E, Zimmermann C, Melz G, Jürgens HU (1997) Heritable improvement of frost tolerance in winter wheat by in vitroselection of hydroxyproline-resistant proline overproducing mutants. Euphytica. 93:1-10.

Gibson S, Arondel V, Iba K, Somerville C (1994) Cloning of a temperature regulated gene encoding a chloroplast w-3 desaturase from Arabidopsis thaliana. Plant Physiol 106:1615-1621.

Herzog $H$ (1987a) Freezing resistance and development of faba beans as affected by ambient temperatures, soil moisture and variety. J Agron Crop Sci 159:90-100.

Herzog $\mathrm{H}$ (1987b) A quantitative method to assess freezing resistance in faba beans. J Agron Crop Sci 158:195-204.

Herzog H (1989) Influence of pre-hardening duration and dehardening temperatures on varietal freezing resistance in faba beans (Vicia faba L.). Agronomie (Paris) 9:55-61.

Herzog $\mathrm{H}$, Olszewski A (1998) A rapid method for measuring freezing resistance in crop plants. J Agron Crop Sci 181:71-79.

Hoffmann-Bahnsen R, Herzog H (2001) Frost resistance-screening in Lupinus albus based on chlorophyll fluorescence measurements: a methodical evaluation and adjustment. 4th European Conference on Grain Legumes. Cracow. Poland. 812 July 2001. 
Kaup MT, Froese CD, Thompson JE (2002) A role for diacylglycerol acyltransferase during leaf senescence. Plant Physiol 129:1616-1626.

Koiwai A, Matsuzaki T, Suzuki F, Kawashima N (1981) Changes in total and polar lipids and their fatty acid composition in tobacco leaves during growth and senescence. Plant Cell Physiol 22:1059-1065.

Lea PJ, Leegood RC (1993) Plant Biochemistry and Molecular Biology. J Wiley \& Sons, Chichester, West Sussex, UK.

Lehninger AL (1977) Biochemistry. $2^{\text {nd }}$ ed. Worth Publisher, New York.

Mackender RO, Leech RM (1974) The galactolipid, phospholipid, and fatty acid composition of the chloroplast envelope membranes of Vicia faba L. Plant Physiol 53:496-502.

McKenzie JS, Paquin R, Duke SH (1988) Cold and heat tolerance. In: Hanson AA, Barnes DK, Hill RR eds, Alfalfa and alfalfa improvement. Agronomy monograph No. 29, ASA, WI, pp. 259-302.

Ohno R, Takumi S, Nakamura C (2001) Expression of cold-responsive Lt-Cor gene and development of freezing tolerance during cold acclimation in wheat (Triticum aestivum L.). J Exp Bot 52:2367-2374.

Petcu E, Terbea M (1995) Proline content and the conductivity test as screening methods for frost tolerance of winter wheat. Bulg J Plant Physiol 21:3-11.

Pollock CJ (1986) Fructans and the metabolism of sucrose in vascular plants. New Phytol 104:1-24.

Rizza F, Crosatti C, Stanca AM, Cativelli L (1994) Studies for assessing the influence of hardening on cold tolerance of barley genotypes. Euphytica 75:131-138.

Santoiani CS, Tognetti JA, Pontis HG, Salerno GL (1993) Sucrose and fructan metabolism in wheat roots at chilling temperatures. Physiol Plant 87:84-88.

Shaner G, Finney RE (1977) The effect of nitrogen fertilization on the expression of slow-mildewing resistance in Knox wheat. Phytopathology 67:1051-1056.

Steel RGD, Torrie JH (1981) Principles and Procedures of Statistics. International student eds, Mcgraw-Hill, New York. 
Taulavuori K, Taulavuori E, Sarjala T, Savonen EM, Pietiläinen P, Lähdesmäki P, Laine K (2000) In vivo chlorophyll fluorescence is not always a good indicator of cold hardiness. J Plant Physiol 157:227-229.

Thies W (1971) Schnelle und einfache Analysen der Fettsäurezusammensetzung in einzelnen Raps-Kotyledonen. I. Gaschromatographische und papierchromatographische Methode. Z Pflanzenzüchtung 65:181-202.

Thomashow MF (1999) Plant cold acclimation: freezing tolerance genes and regulatory mechanisms. Annu Rev Plant Physiol Plant Mol 50:571-599.

Utz HF (1991) A computer program for statistical analysis of plant breeding experiments. Institute of Plant Breeding, Seed Science and Population Genetics. University of Hohenheim.

Vigh L, Maresca B, Harwood JL (1998) Does the membrane's physical state control the expression of heat shock and other genes? Trends Biochem. Science 2:69374.

Wei H, Dhanaraj AL, Arora R, Rowland LJ, Fu Y, Sun L (2006) Identification of cold acclimation-responsive Rhododendron genes for lipid metabolism, membrane transport and lignin biosynthesis: importance of moderately abundant ESTs in genomic studies. Plant Cell Environment 29:558-570. 


\section{Quantitative trait loci of frost tolerance and physiologically related trait in faba bean (Vicia faba L.)}

M. Arbaoui, A.M. Torres, and W. Link (prepared for TAG)

\section{Abstract}

Field based winter-hardiness is a complex trait. Frost tolerance was proven to explain a large part of its genetic variability in faba bean. Frost tolerance could be used to indirectly select for faba bean winter-hardiness. The aim of this study was to identify putative QTL associated with frost tolerance and its auxiliary traits and to quantify the efficiency of marker assisted selection (MAS) as compared to classical phenotypic selection (CPS). To do so, 101 recombinant inbred lines (RIL) derived from the cross between two frost tolerant lines (the European line Côte d'Or/1 and the exotic line BPL 4628) were tested for their hardened and unhardened frost tolerance in controlled conditions and for their fatty acid content before and after hardening. The LOD threshold to declare putative QTL was fixed according to the Bonferroni correction. Cross-validation (CV) was additionally performed in order to assess the unbiased genotypic proportion explained. Significant differences among the RIL were observed for all studied traits. For frost tolerance, four different putative QTL were detected; two for unhardened frost tolerance that explained $28.3 \%$ (3.44\% after CV) of its genotypic variance and two for hardened frost tolerance that explained $12.5 \%$ (5.22\% after CV). For fatty acid content, three QTL were detected for oleic acid content in unhardened leaves that explained $57.7 \%$ (37.2\% after CV) of its genotypic variance. This fatty acid was significantly correlated with unhardened frost tolerance. The unbiased genotypic variance explained (after CV) enabled to draw realistic prospects of MAS for frost tolerance. Thus, combined MAS and CPS was more efficient than CPS alone. Such efficiency was expected to be even higher on large populations at early generations. Moreover, favourable alleles inherited from the exotic line BPL 4628 could be introgressed to other European winter-hardy beans for further improvement.

\section{Introduction}

In most North and Central European countries, freezing temperatures below $-6^{\circ} \mathrm{C}$ (Herzog, 1987) during winter are one of the major limitations for growing autumnsown faba bean (Vicia faba L.). The superiority of winter types over spring types for 
protein and grain yield, and the crucial impact of complete overwintering on grain yield emphasise the importance of improving faba bean winter-hardiness.

Field-based winter-hardiness is a complex trait resulting from the combined expression of several auxiliary traits such as frost tolerance and resistance to biotic winter stress. The irregular occurrence of appropriate natural freezing temperatures that allow differentiation among genotypes is also a major problem. Unless results from many environments are available, heritability and gain from selection for winterhardiness is expected to be low. In order to reach a high reproducibility, experiments under controlled conditions were developed to analyse frost tolerance. In several crop species, frost tolerance was found to be a main component of winter-hardiness (Rizza et al, 1994; Petcu and Terbea 1995; Arbaoui et al., 2007). The frost tolerance of a plant was defined as (1) its unhardened frost tolerance and (2) its hardening response. Both traits were found to be inherited independently (Stone et al., 1993). Hardening, also known as cold acclimation is the result of an exposure to low nonfreezing temperatures (Levitt, 1980). It increases significantly plant frost tolerance (Herzog, 1987; Rizza et al., 1994; Petku and Terbea, 1995; Badaruddin and Meyer, 2001; Arbaoui et al., 2007).

Responses of plants to hardening were observed on oligogenic traits such as (1) accumulation of sucrose and fructans (Pollock, 1986; Santoiani et al., 1993), (2) increase of total protein concentration (Davis and Gilbert; 1970; McKenzie et al., 1988), (3) accumulation of free proline (Petcu et al., 1995; Dörffling et al., 1997; Thomashow, 1999), (4) increase of the cell membranes stability (Chandrasekar et al., 2000), (5) increase of total lipids and their polyunsaturated fatty acid content (linoleic and linolenic acids), and (6) increase of desaturase enzyme activity (Cyril et al., 2002; Wei et al., 2005). Recent studies showed that polyunsaturated fatty acid and proline accumulation were adaptation mechanisms to low non-freezing temperatures, but also significant correlated traits to frost tolerance (Arbaoui et al., 2007).

During the past 15 years, many genetic linkage maps were developed to locate DNA markers linked to quantitative trait loci (QTL) involved in the inheritance of important agronomic traits. These putative QTL usually explain a significant proportion of the phenotypic variance of a trait. Under the assumption of equal heritability for all detected QTL, their explained proportion of the genotypic variance was as well assessed. Based on this proportion and on the heritability of the trait, the efficiency of 
marker assisted selection (MAS) compared with classical phenotypic selection (CPS) was determined. Whereas MAS was successfully applied in some breeding programs (Fridman et al., 2000; Yousef and Juvik, 2001), it failed in other programs (Openshaw and Frascarolli, 1997; Bouchez et al., 2002), mainly because of an overestimation of the genotypic variance explained (Utz and Melchinger, 1994; Beavis, 1998). This overestimation is partly due to a restricted population size, a limited genome coverage, and a non congruency of the QTL over generations and populations.

In faba bean breeding, genetic linkage maps were recently developed to identify QTL for seed quality and resistance to biotic stress (Román et al., 2002; Román et al., 2003), but none for tolerance to abiotic stress.

The objective of this study was (1) to develop a genetic linkage map on a faba bean RIL population, (2) to identify, map, and assess the genetic effect of QTL associated with frost tolerance and related trait, (3) to reassess the proportion of the genotypic variance explained by all putative QTL via re-sampling, and (4) to determine the relative efficiency of MAS vs. CPS for frost tolerance.

\section{Materials and Methods}

Plant material

Two frost tolerant inbred lines were used as parents: Côte d'Or 1 (inbred line derived from the winter-hardy French landrace Côte d'Or), and BeanPureLine 4628 (BPL, Chinese inbred line from the ICARDA germplasm collection). The findings of Duc and PetitJean (1995) and the provenience of both lines from distant geographical areas was taken as promise of a large segregation for frost tolerance in the progeny of this cross. Randomly chosen F2 plants were advanced by single seed descent to produce $\mathrm{N}=101 \mathrm{~F} 6$ derived recombinant inbred lines (RIL). Frost tolerance in artificial frost tests and fatty acid composition in leaves were measured on these lines and on their parental lines with and without hardening.

During germination and emergence the temperature was kept at $10^{\circ} \mathrm{C}$ days $/ 3^{\circ} \mathrm{C}$ nights for 14 days to produce hardened seedlings, and at $18^{\circ} \mathrm{C}$ days $/ 15^{\circ} \mathrm{C}$ nights for 10 days to produce unhardened seedlings. For every genotype, four seedlings were grown in a pot $\left(17 \times 17 \times 17 \mathrm{~cm}^{3}\right)$ filled with $5 \mathrm{~kg}$ of soil $(1: 1$ mixture of sand and compost). The soil was kept between $70 \%$ and $80 \%$ of its water capacity. 
Phenotypic data

\section{Artificial frost tests}

The experiments were conducted in a plant growth chamber $\left(2 \times 2 \times 2 \mathrm{~m}^{3}\right)$, which can produce freezing temperatures. When the seedlings reached two expanded leaves, all pots were transferred to (i.e. loaded to) the frost chamber. One such transfer was called a load. Before testing, hardened seedlings were further exposed to temperature of $2.5^{\circ} \mathrm{C}$ days $/ 0^{\circ} \mathrm{C}$ nights during one $w$ eek. Light in the frost chamber was programmed at $200 \mu \mathrm{mol} \mathrm{s} \mathrm{m}^{-1}$ during 12 hours. The air humidity was freely fluctuating between $80 \%$ and $90 \%$ according to temperature fluctuation.

The test included six steps of decreasing freezing air temperatures during "night" and thawing during the artificial "day" (Figure 1). After each step, and after ten hours of thawing, first leaf, second leaf, and stem were individually and visually scored on every seedling (Herzog 1987; Duc and PetitJean, 1995) for colour (1 = green, $4=$ black), and turgidity ( 1 = fully turgid, $4=$ not turgid). For each of the six traits, injury scores resulting from every step were combined as follows. For each step, the product of actual freezing temperature $\left({ }^{\circ} \mathrm{C}\right)$ and duration of freezing temperature under minus $6^{\circ} \mathrm{C}$ (hours) was calculated to determine the number of degree-hours ('C h). The injury score at each freezing step was then multiplied with its corresponding number of degree-hours and added across the six steps to produce the "Area Under Symptom Progress Curve" (AUSPC; corresponding to the "Area Under Disease Progress Curve", AUDPC; Shaner and Finney, 1977).

Fatty acid analyses

First leaves of hardened and unhardened seedlings were analyzed for fatty acid composition of their total lipid content. Once they reached two expanded leaves, shoots were cut, dried at $50^{\circ} \mathrm{C}$ during 48 hours, and grinded to fine powder. Total tissue lipid extraction followed the experimental protocol of Thies (1971). The total fatty acid composition was analyzed by gas chromatography (Perkin Elmer 8600). Three-microliter samples were manually injected into column (Permabond FFAP-0.25 $\mu \mathrm{m}, 25 \mathrm{~m} \times 0.25 \mathrm{~mm}$ ). The column temperature was maintained at $215^{\circ} \mathrm{C}$. Injector temperature was at $280^{\circ} \mathrm{C}$, and detector temperature at $280^{\circ} \mathrm{C}$. The carrier gas was hydrogen at a pressure of $100 \mathrm{kPa}$. The individual peaks were identified based on comparisons to a standard sample. Quantity of each fatty acid was expressed as relative percentage of the total fatty acids content. 


\section{Marker data}

Leaf tissue from the $101 \mathrm{~F} 6 \mathrm{RIL}$ and the two parental lines was collected and freeze dried. Genomic DNA was extracted as described by the Nucleon and PhytoPure extraction kit (Amersham Biosciences Corp., 2003). To construct the genetic linkage map, RAPD primers were used. The RAPD analyses were performed following the experimental protocol of Williams et al. (1990), with slight modifications (Torres et al., 1993). The two parental lines were screened for polymorphism with a total of 144 RAPD primers. Thirty one primers revealing intense and clearly scorable polymorphic bands were selected to further analyse the present F6 population.

Statistics

\section{Phenotypic data}

For artificial frost tests, the 101 F6 RIL and the two parental lines were analyzed in three experiments in both treatments (with and without hardening). Two experiments were laid out as lattice with three replicates and one with two; one replicate corresponding to one load of the plant growth chamber. In both treatments, the lattice adjusted AUSPC mean across the six traits and all experiments of each inbred line was considered as the phenotypic expression of frost tolerance.

For fatty acid analyses, in both treatments the 101 F6 RIL and the two parental lines were randomized in three experiments. Each experiment was laid out as randomized complete blocks with two replicates; one replicate of a genotype comprising a mixture of first leaves from two plants. In both treatments, the mean across the replicates and the experiments was calculated for each identified fatty acid. From these means and in each fatty acid the difference between hardened and unhardened content was also calculated and considered as the hardening response.

In order to determine significant sources of variation and to assess heritability $\left(h^{2}=\frac{\sigma_{G}^{2}}{\sigma_{P}^{2}}\right)$, an analysis of variance was performed using Plabstat $(U t z, 1991)$. For fatty acids, to test the hardening response for significance and to quantify its heritability, the genotype $x$ treatment interactions was taken as source of variation. 
In order to test for a useful relationship between (1) content and changes in fatty acid composition and (2) frost tolerance, correlation analyses were performed between these traits.

\section{Marker data}

At each RAPD marker locus, deviations from the expected Mendelian segregation ratio (1:1) were tested by Chi-square tests. Based on the 101 F6 RIL, a genetic linkage map was constructed using MAPMAKER Version 3 (Lander et al., 1987). The threshold LOD score used was 3.00 to declare linkage between two markers. After determining linkage groups (LG), the recombination fractions were converted to centimorgans (cM) using the mapping function of Haldane (1919).

QTL analyses

The QTL mapping and estimation of their effects were performed using PLABQTL (Utz and Melchinger, 1996). Analyses were performed with means of the 101 F6 RIL for all measured traits. The method of composite interval mapping (CIM) with cofactors (Jansen and Stam, 1994) was used for detecting, mapping, and characterising QTL. To declare a putative QTL, the minimum LOD score was fixed according to the Bonferroni correction. Thus, in this study, with 89 marker intervals tested and two degrees of freedom, the LOD threshold was fixed to 3.25 to ensure the experiment-wise significance level of $95 \%$. Two putative QTL if inherited from the same parent and if mapped within a distance of $20 \mathrm{cM}$ were declared congruent (Melchinger et al., 1998).

The proportion of the phenotypic variance explained by one QTL was determined by its partial coefficient of determination $\mathrm{R}^{2}$. The phenotypic proportion explained by all detected QTL was taken as the adjusted coefficient of determination $\mathrm{R}^{2}$ adj as described by Utz et al. (2000). Assuming that the heritability of the studied trait was the same for all detected QTL, the corresponding genotypic proportion explained from the whole data set ( $p_{D S}$; Schön et al., 2004) was determined from the ratio:

$p_{D S}=\frac{R_{a d j}^{2}}{h^{2}}$

In order to avoid an overestimation of $\mathrm{p}_{\mathrm{DS}}$ due to the restricted population size $(\mathrm{N}=$ 101) used in this study, a re-sampling method, the fivefold cross-validation (CV), was performed as implemented in PLABQTL. Test sets comprising $20 \%$ of the genotypes 
were used for determining the unbiased estimation of the genotypic variance explained by all detected QTL (p $\mathrm{p}_{\text {TS }}$; Utz et al., 2000; Schön et al., 2004). These estimates were used to assess the prospects of pure MAS (based on marker data) and of combined MAS (based on phenotypic and marker data) for frost tolerance (Lande and Thompson; 1990).

\section{Results}

Phenotypic data

\section{Artificial frost tests}

Exposure to hardening had a significant effect on frost tolerance across lines and repetitions. Although the two parental lines had similar AUSPC in both treatments (details not shown), the significant differences among the $101 \mathrm{~F} 6 \mathrm{RIL}$ proved that Côte d'Or 1 and BPL 4628 were genetically different for frost tolerance (Table 1). Moreover, the identification of 27 RIL (including F6-33, F6-95, and F6-69) significantly better performing than both parental lines corroborated the complementarities of Côte d'Or/1 and BPL 4628 for alleles coding for frost tolerance. The heritability of genotypes for mean frost tolerance was high $\left(h^{2}=0.778\right)$, and intermediate for frost tolerance after hardening $\left(h^{2}=0.656\right)$ and before hardening $\left(h^{2}\right.$ = 0.669; details not shown). The significant genotype $\mathrm{x}$ treatment interactions showed that genotypes were different for their hardening response (Figure 2).

\section{Fatty acid analyses}

Among the ten fatty acids identified, six were further analyzed because they represented more than $95 \%$ of the total composition: palmitic acid (16:0), stearic acid (18:0), oleic acid (18:1), linoleic acid (18:2), linolenic acid (18:3), and stearidonic acid (18:4). The main fatty acid in leaves was 18:3 (Table 2).

Hardening had a significant effect on 18:1 and 18:2 content. Although a marked increase was observed for 18:3 content due to hardening, it was not significant. Across treatments and replicates, the lines were significantly different for their fatty acid composition. The heritability of the genotypes and their hardening response were very different among the fatty acids (Table 3). The ANOVA for fatty acid composition in each treatment revealed significant differences between the RIL. The heritability estimates were $0.297<\mathrm{h}^{2}<0.884$; this highest heritability was observed in unhardened 18:1 content (further details not shown). 
Oleic acid content in unhardened leaves was significantly correlated with polyunsaturated fatty acid content in unhardened leaves $\left(r=-0.841^{\star *}\right)$ and to the increase of polyunsaturated fatty acid content due to hardening $\left(r=0.545^{\star \star}\right)$. Thus, high initial amount of $18: 1$ led to higher increase of $18: 2+18: 3$, likely from its desaturation due to hardening. The changes in content of $18: 1$ and of $18: 2+18: 3$ were correlated $\left(r=-0.748^{* *}\right.$; Figure 3$)$.

\section{Correlation analyses}

In several plant species, significant relationship between polyunsaturated fatty acid content in leaves and frost tolerance was observed (Cyril et al., 2002; Arbaoui et al., 2007). In the present study, significant correlations were found between $18: 1$ ( $r=$ $0.318^{* *}$; Figure 4) and 18:2+18:3 $\left(r=-0.231^{*}\right)$ content in unhardened leaves with unhardened AUSPC. Significant correlations were also found between unhardened 18:0 content and hardened AUSPC $\left(r=0.299^{* *}\right)$. Although significant, the low correlation values prevented the use of fatty acid composition as a tool to directly select for frost tolerance.

\section{Linkage map}

Out of the 31 RAPD primers, 164 marker loci were chosen to construct the genetic linkage map. Nineteen out of the 164 showed significant deviations from the expected segregation ratio $(1: 1)$ and were therefore discarded. Through the whole covered genome and across the $101 \mathrm{~F} 6 \mathrm{RIL}$, the proportion of the parent BPL 4628 was $49.27 \%$. Based on the 145 marker loci, 108 were mapped into 19 linkage groups (LG). Linkage groups encompassed 2 to 19 marker loci, covering a total map distance of $1487.4 \mathrm{cM}$, with an average interval length of $10.3 \mathrm{cM}$. About $99.6 \%$ of the mapped genome was located within a $20 \mathrm{cM}$ distance to the nearest marker (Figure 5).

QTL analyses

\section{Frost tolerance}

Frost tolerance of a plant was considered as the combination of its unhardened and hardened frost tolerance.

Two putative QTL were detected for the unhardened AUSPC. One favourable allele was inherited from each parent. The phenotypic variance explained by the two QTL 
was $18.9 \%$, which corresponded to $28.3 \%$ of the genotypic variance. The fivefold cross-validation (CV) tests revealed a high bias included in the estimate of the genotypic variance explained proportion ( $p_{T S}=3.44 \%$ ).

For the hardened AUSPC, two putative QTL were detected but on different linkage groups. The favourable alleles originated similarly from both parents. These QTL explained $8.2 \%$ of the phenotypic variance, and $12.5 \%$ of the genotypic variance (Table 4). The proportion of the genotypic variance explained was reduced by CV to $\mathrm{p}_{\mathrm{TS}}=5.22 \%$.

\section{Fatty acid composition}

In order to avoid overestimation of the genotypic variance explained, it was decided to discard the following fatty acid traits due to their low heritability $\left(h^{2}<0.50\right)$ : hardened and unhardened 18:4 content, changes in 16:0 and in 18:4 content due to hardening.

With hardening, no QTL were detected that could explain a significant proportion of the variation observed in fatty acid content, except one QTL for 18:3. Nevertheless, the CV revealed that the proportion explained by this QTL was extremely overestimated. Without hardening, a range of one to three putative QTL was detected for each fatty acid. Across fatty acids, all detected QTL explained 6.0 to $50.8 \%$ of the phenotypic variance and 8.2 to $57.7 \%$ of the genotypic variance. The

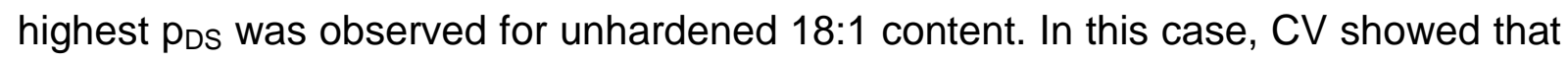
$37.21 \%$ could be accounted to the unbiased explained proportion of the genotypic variance. One QTL associated with 18:0, with 18:1 and with 18:3 content in unhardened leaves, respectively, was mapped on the LG4 (Figure 5). For the hardening response, one putative QTL was associated with changes in 18:1 content that explained $33.1 \%(14.65 \%$ after CV) of the genotypic variance. Two putative QTL were detected for hardening response of 18:2 content. Across both QTL, $\mathrm{P}_{\mathrm{DS}}$ was $33.7 \%$. According to the $\mathrm{CV}$, the bias in this genotypic variance explained was high. On LG12, within $20 \mathrm{cM}$ distance, QTL associated with unhardened 18:1 content, with changes due to hardening in 18:1 and in 18:2 content, was mapped.

\section{Discussion}

In faba bean, frost tolerance was found to be highly heritable due to large additive effects (Duc and PetitJean, 1995). In a large population of recombinant inbred lines 
segregating for frost tolerance, the power of QTL detection is expected to be high. In this study, based on 101 F6 RIL, a total of four putative QTL was detected for frost tolerance. In both traits a favourable allele was inherited from each parent, as was expected from their similar phenotypic frost tolerance. These findings proposed complementarities of the parents for other non-detected QTL linked to frost tolerance genes.

Despite significant phenotypic differences among RIL, a limited proportion of the frost tolerance (hardened and unhardened) was explained since not all possible allele recombinations for frost tolerance were covered, because of the small population size. The low unbiased proportion of the genotypic variance explained proposed that the frost tolerance is a polygenic trait which might not be controlled by few major QTL. Simulations (Beavis, 1998) and experimental studies (Schön et al., 2004) showed that for polygenic traits, the proportion of the unbiased genotypic variance explained by individual detected QTL was indeed low. Thus, with a larger population and similar framework map, an increase of $p_{T S}$ for frost tolerance would rather result from the increase of the power of detection than from the increase of partial $R^{2}$ of individual QTL. Thus, in back cross breeding programs assisted by markers, since the necessary initial population size increase accordingly to the number of markers (QTL) implemented (Hospital and Charcosset, 1997), an increased power of detection might not be very useful for practical limitations unless QTL with higher $\mathrm{R}^{2}$ are detected. In comparison to previous QTL studies based on small population for polygenic traits, the low reported proportion of the genotypic variance explained of frost tolerance was due (1) to the rather strict LOD threshold (3.25) to declare putative QTL as proposed by Knapp (1998), and especially due (2) to the crossvalidation (Utz et al., 2000; Melchinger et al., 2004).

Putative QTL were detected to be associated with fatty acid content in unhardened leaves and with their hardening response. Four of these QTL were mapped on LG4 but at different positions (QTL interval distance $>20 \mathrm{cM}$ ). This result proposed that this linkage group might be the main site of fatty acid synthesis and desaturation. On LG12, the three putative QTL mapped within an interval of $20 \mathrm{cM}$ can be considered as congruent. Thus, this "one" putative QTL seemed to be associated with the synthesis of unhardened 18:1 content and the hardening response of 18:1 and 18:2. Taking into account the pathway of polyunsaturated fatty acid synthesis (Wei et al., 2005), it is plausible to detect one QTL having a significant simultaneous effect on 
18:1 decrease and 18:2 increase due to hardening. The opposite signs of the QTL effects on both traits support this conclusion. Likely enough, this QTL could contain a locus coding for an oleoyl desaturase enzyme.

The genotypic variance of unhardened 18:1 content was to a large extent explained by three putative QTL ( $\mathrm{p}_{\mathrm{DS}}=57.7 \%$ and $\mathrm{p}_{\mathrm{TS}}=37.21 \%$ ). In comparison to the unbiased genotypic variance of frost tolerance explained, the large $\mathrm{p}_{\text {TS }}$ of 18:1 content suggested that this trait is oligogenic. From simulation studies, Beavis (1998) showed for a trait controlled by 10 QTL with additive effects of equal size and a heritability of $63 \%$, it should be possible with $100 \mathrm{~F} 2$ progenies to detect $35 \%$ of all QTL that would consequently explain $35 \%$ of the genotypic variance. In this study, at equal population sample size, higher genotypic variance explained was observed apparently because (1) there are no evidences from literature that $18: 1$ content is controlled by as many loci, (2) the heritability of the trait was higher (0.884), and (3) the population type was different (F6 RIL vs. F2 progenies). From this result, the content of the other fatty acids could be as well considered as oligogenic and high power of detection was hence expected. However, for each further fatty acid, the power of detection and the unbiased genotypic variance explained were rather low (Table 4). One reason could be the limited genome size covered by the marker loci. Indeed, 37 polymorphic markers were not mapped into LG and not used in the QTL analyses.

In the correlation analyses among the phenotypic traits, significant correlations were found between fatty acid composition, their changes due to hardening and hardened as well as unhardened frost tolerance. Because of the significant relationships among fatty acids, in each treatment, only the highest correlation between frost tolerance and fatty acid was further analyzed to avoid redundant information. For the unhardened AUSPC, the highest correlation was observed with unhardened 18:1 content $\left(r=0.318^{* *}\right)$. The coefficient of regression of unhardened AUSPC on unhardened 18:1 content was significant and $10.09 \%$ of the adjusted phenotypic variance of unhardened frost tolerance was explained by this fatty acid. Using the heritability of both traits, the genotypic variance explained by unhardened 18:1 content was assessed to $17.06 \%$. Although putative QTL detected for these two traits were mapped on different LG with LOD threshold of 3.25, some of the three QTL detected for unhardened 18:1 content may also be associated with unhardened frost tolerance. To test this hypothesis, the LOD threshold to declare putative QTL was 
reduced to $L O D=1.5$. As result, two of the three putative $Q T L$ detected for unhardened 18:1 content were tightly linked to additionally identified QTL for unhardened frost tolerance. The first QTL ("18:1"; E1_1118, LOD = 3.52) was linked to I6_425 (unhardened AUSPC; LOD = 2.91) within an interval distance of $24.2 \mathrm{cM}$. Both QTL increased respectively unhardened $18: 1$ content $(+0.43 \%)$ and unhardened frost tolerance (-29.79 scoreunit ${ }^{\circ} \mathrm{C} h$ ); thus corro borating the phenotypic correlation between these two traits. However, the distance between the two QTL does not clearly propose that they are congruent. The second QTL ("18:1"; L3_1330, LOD = 6.11) was linked to E20_329 (unhardened AUSPC; LOD = 1.57) within an interval distance of $12.0 \mathrm{cM}$. In this case, congruency was more likely, all the more that this QTL was detected in one of the cross validation subset of the unhardened AUSPC. This second QTL explained 9.7\% of the adjusted phenotypic variance of unhardened frost tolerance; corresponding to $14.49 \%$ of the adjusted genotypic variance explained. The maximum of the unhardened frost tolerance genotypic variance explainable by unhardened 18:1 content being 17.06\%, this QTL seemed to explain main part of it. For hardened frost tolerance, although significant correlations were found between hardened AUSPC and unhardened 18:0 content $\left(r=0.299^{* *}\right)$, hardened 18:3 content $\left(r=-0.221^{*}\right)$, decreasing the LOD threshold to 1.5 did not reveal putative fatty acid QTL involved in the inheritance of hardened frost tolerance. Thus, in addition to the four QTL detected for frost tolerance, the QTL linked to L3_1330 could be used to explain part of frost tolerance. In order to reduce the bias of its partial phenotypic $R^{2}$, its additional contribution to the p of unhardened frost tolerance was reassessed by multiplying (1) its relative contribution to $p_{D S}(19.81 \%)$ of unhardened 18:1 content and (2) the genotypic proportion of unhardened frost tolerance explained by the unhardened $18: 1$ content (17.06\%). Thus, this third putative QTL associated with unhardened frost tolerance was considered to explain $3.38 \%$ of its genotypic variance.

Under the assumption of equal heritability of all detected QTL for one trait and equal selection intensity, the formula of Lande and Thompson (1990) was applied to determine the relative efficiency (RE) of pure and combined MAS for unhardened and hardened frost tolerance (Table 5). The relative efficiency of the pure MAS was lower than 1 irrespective of the proportion of the genotypic variance explained. On the other hand, the RE of the combined MAS was slightly higher than 1. 
For a higher pure MAS efficiency than classical phenotypic selection on the studied population, the power of detection should dramatically increase in order that $\mathrm{p}_{\mathrm{DS}}$ or pTs exceed the heritability. However, simulation and experimental studies showed that for polygenic trait although large population size are used, the genotypic proportion explained does not exceed the heritability (Beavis, 1998; Micic et al., 2004; Schön et al., 2004; Vales et al., 2005). Thus, in such case, the classical phenotypic selection could be expected to be more efficient than pure MAS. On the other hand, in case of (1) congruent QTL over generations and populations, (2) low heritability, and (3) lower costs to develop marker data than phenotypic data, the RE efficiency of pure MAS on other material than the studied one is expected higher than CPS (Moreau et al., 1998; Lange and Whittaker, 2001). Indeed, the costs due to the high number of experiments required to reach a heritability of 0.663 for frost tolerance were high. If the present marker data were available and only one experiment with three replicates was performed, the RE of pure MAS, using $\mathrm{p}_{D S}$, would have been higher and slightly more efficient than CPS for unhardened frost tolerance $(\mathrm{RE}=$ 1.07; further details not shown).

In case of combined MAS, its RE based on $\mathrm{p}_{\mathrm{DS}}$ and $\mathrm{p}_{T S}$ was at least equal to CPS, even on the studied population. Similarly to pure MAS, this efficiency was getting higher if with the same marker data, the selection was applied on data from one experiment with three replicates $\left(R E=1.29\right.$ and 1.07 with $p_{D S}$ and 1.03 with $p_{T S}$ for unhardened and hardened frost tolerance, respectively). Several studies indeed proposed to use combined MAS in breeding programs (Romagosa et al., 1999), especially on large populations at the first generations (Hospital et al., 1997).

The putative QTL detected for fatty acids in leaves and for the potential oleoyl desaturase enzyme opened good perspectives in the understanding of physiological traits involved in the mechanisms of adaptation to hardening. The QTL analyses for frost tolerance proposed that the trait is controlled by several QTL with small effects. Based on the five putative QTL detected for unhardened and hardened frost tolerance, the RE of combined MAS suggested good prospects, and particularly for mass selection on large population sets and at early generations. However, from these first results, further studies should be undertaken with larger population to validate these five QTL, to increase the power of detection, and to consequently increase the proportion of the genotypic variance explained. In a larger scale, this QTL map mainly constructed for frost tolerance could as well be used to study faba 
bean drought tolerance, since these two traits share several basic physiological features.

\section{Acknowledgements}

This work was supported by funds from the commission of the European Communities, specific Research Program Quality of Life and Management of Living Resources, QLK5-2001-02307. It does not necessarily reflect its views and in no way anticipates the Commissions' future policy in this area. The authors thank NPZLembke Company for their financial contribution. 
Table III-1. Analysis of variance of frost tolerance (AUSPC, area under symptom progress curve).

\begin{tabular}{|c|c|c|c|}
\hline Sources of variation & $\overline{D F}$ & MS $\left(\times 10^{4}\right)$ & $\mathrm{F}$ \\
\hline Treatments & 1 & 17970.18 & $162.28^{* *}$ \\
\hline Experiments / $\mathrm{T}$ & 4 & 110.74 & $139.73^{* *}$ \\
\hline Genotypes & 100 & 3.57 & $4.50^{* *}$ \\
\hline Genotype $x$ treatment & 100 & 1.09 & $1.37^{\star}$ \\
\hline$G \times E / T$ & 331 & 0.79 & $1.59^{* *}$ \\
\hline Error & 553 & 0.50 & \\
\hline $\begin{array}{l}\text { Heritability of } G \\
\text { Heritability of } G \times T\end{array}$ & $\begin{array}{l}0.778 \\
0.280\end{array}$ & & \\
\hline
\end{tabular}

Table III-2. Mean fatty acid composition (\%) of hardened and unhardened first leaf across genotypes and repetitions.

\begin{tabular}{lcccccc}
\hline Treatment & $16: 0$ & $18: 0$ & $18: 1$ & $18: 2$ & $18: 3$ & $18: 4$ \\
\hline Hardened & 10.02 & 1.41 & 4.61 & 20.58 & 55.26 & 5.07 \\
Unhardened & 10.58 & 1.29 & 8.22 & 17.44 & 52.30 & 7.09 \\
Average & 10.30 & 1.35 & 6.41 & 19.01 & 53.78 & 6.08 \\
\hline
\end{tabular}

Table III-3. Analysis of variance for main fatty acid composition (\%). F-values and heritability.

\begin{tabular}{|c|c|c|c|c|c|c|c|}
\hline Sources of variation & DF & 16:0 & 18:0 & $18: 1$ & $18: 2$ & $18: 3$ & $18: 4$ \\
\hline Treatments & 1 & 0.90 & 0.71 & $62.33^{\star \star}$ & $12.43^{*}$ & 2.58 & $161.26^{\star \star}$ \\
\hline Experiments / $\mathrm{T}$ & 4 & $58.01^{* *}$ & $155.38^{* *}$ & $127.36^{\star *}$ & $108.46^{\star *}$ & $140.88^{* *}$ & 1.33 \\
\hline Replicates / E x T & 6 & $8.25^{\star *}$ & $3.39^{* *}$ & $2.30^{\star}$ & $2.95^{\star \star}$ & $8.42^{\star *}$ & $18.98^{* *}$ \\
\hline Genotypes & 100 & $5.58^{* *}$ & $4.67^{* *}$ & $10.83^{\star *}$ & $5.18^{\star \star}$ & $5.36^{\star \star}$ & $2.15^{\star \star}$ \\
\hline $\mathrm{G} \times \mathrm{T}$ & 100 & $1.47^{* *}$ & $2.75^{\star \star}$ & $4.06^{* *}$ & $2.78^{\star \star}$ & $2.54^{\star *}$ & 1.08 \\
\hline$G \times E / T$ & 400 & $2.33^{\star *}$ & $2.12^{\star *}$ & $4.07^{* *}$ & $3.71^{\star *}$ & $4.35^{\star *}$ & $2.55^{\star *}$ \\
\hline Error & 600 & & & & & & \\
\hline Heritability of $\mathrm{G}$ & & 0.821 & 0.786 & 0.908 & 0.807 & 0.814 & 0.534 \\
\hline Heritability of $G \times T$ & & 0.321 & 0.636 & 0.754 & 0.641 & 0.606 & 0.074 \\
\hline
\end{tabular}


Table III-4. Parameters associated with putative quantitative trait loci (QTL) for frost tolerance and fatty acid composition in both treatments assessed from genotypic and phenotypic data of 101 F6 recombinant inbred lines from the cross Côte d'Or 1 x BPL 4628 .

\begin{tabular}{|c|c|c|c|c|c|c|c|c|c|c|c|c|c|c|}
\hline \multirow{4}{*}{$\begin{array}{l}\text { Traits } \\
\text { Linkage } \\
\text { Groups (LG) }\end{array}$} & \multirow{2}{*}{\multicolumn{4}{|c|}{ Frost tolerance }} & \multicolumn{10}{|c|}{ Fatty acid composition } \\
\hline & & & & & \multicolumn{7}{|l|}{$\begin{array}{l}\text { unhardened } \\
\text { und }\end{array}$} & \multicolumn{3}{|l|}{ Changes } \\
\hline & \multicolumn{2}{|c|}{ unhardened } & \multicolumn{2}{|l|}{ hardened } & $16: 0$ & 18:0 & \multicolumn{2}{|l|}{$18: 1$} & & \multirow{2}{*}{$\begin{array}{l:l}18: 2 \\
\text { LG5 }\end{array}$} & \multirow{2}{*}{$\begin{array}{l}18: 3 \\
\text { LG4 }\end{array}$} & \multirow{2}{*}{$\begin{array}{l}18: 1 \\
\text { LG12 }\end{array}$} & \multicolumn{2}{|l|}{ 18:2 } \\
\hline & LG11 & LG6 & LG9 & LG10 & LG15 & LG4 & LG12 & LG4 & LG14 & & & & LG12 & LG4 \\
\hline Marker & B20_803 & O18_737 & K3_1529 & B20_600 & 018_1166 & G18_1257 & C6_768 & L3_1330 & E1_1118 & M18_1220 & F9_940 & C6_768 & C6_768 & E20_1556 \\
\hline $\begin{array}{l}\text { Position on } \\
\text { LG (cM) }\end{array}$ & 54 & 48 & 216 & 0 & 60 & 106 & 4 & 290 & 8 & 64 & 42 & 0 & 6 & 270 \\
\hline $\begin{array}{l}\text { LOD at QTL } \\
\text { position }\end{array}$ & 3.83 & 3.54 & 4.28 & 4.54 & 4.05 & 6.08 & 7.66 & 6.11 & 3.52 & 3.56 & 3.59 & 4.94 & 4.56 & 4.06 \\
\hline Additive effect & -32.40 & 27.23 & 24.89 & -19.54 & 10.60 & 1.29 & 0.71 & -0.46 & 0.39 & -0.49 & 0.80 & -0.57 & 0.76 & -0.63 \\
\hline $\begin{array}{l}\text { Phenotypic } \\
\text { variance } \\
\text { explained (\%) }\end{array}$ & 12.90 & 8.70 & 8.30 & 5.90 & 9.20 & 21.50 & 36.60 & 24.10 & 11.70 & 7.90 & 11.60 & 26.40 & 16.70 & 13.00 \\
\hline $\mathrm{p}_{\mathrm{DS}}(\%)$ & 28 & 8.3 & 12 & & 11.2 & 30.2 & & 57.7 & & 8.2 & 12.9 & 33.1 & & 33.7 \\
\hline $\mathrm{p}_{\text {TS }}(\%)$ & & .4 & 5. & & 3.6 & 1.0 & & 37.2 & & 0.0 & 4.7 & 11.0 & & 1.0 \\
\hline
\end{tabular}

$\mathrm{p}_{\mathrm{DS}}$ and $\mathrm{p}_{\mathrm{TS}}$ were the estimate of the adjusted proportion of the genotypic variance explained from the whole data set and the unbiased proportion of the genotypic variance explained by test sets from cross-validation.

The variance explained by each QTL corresponds to their phenotypic partial coefficient of determination. 
Table III-5. Relative efficiency (RE) of marker assisted selection (MAS) for frost tolerance based on pure MAS or combined MAS using phenotypic and marker data.

\begin{tabular}{|c|c|c|c|}
\hline \multirow{2}{*}{ Method } & \multirow{2}{*}{$\begin{array}{c}\text { Explained proportion } \\
\text { (p) }\end{array}$} & unhardened AUSPC & hardened AUSPC \\
\hline & & 3 QTL & 2 QTL \\
\hline \multirow{2}{*}{ pure MAS } & $p_{D S}$ & 0.69 & 0.44 \\
\hline & pTS & 0.23 & 0.28 \\
\hline \multirow{2}{*}{ cMAS } & $\mathrm{p}_{\mathrm{DS}}$ & 1.03 & 1.01 \\
\hline & $\mathrm{p}_{\mathrm{TS}}$ & 1.00 & 1.00 \\
\hline
\end{tabular}

Formula of Lande and Thompson (1990):

Pure MAS, RE $=\sqrt{\frac{p_{i}}{h_{i}^{2}}}$

Combined MAS, RE $=\sqrt{\frac{p_{i}}{h_{i}^{2}}+\frac{\left(1-p_{i}\right)^{2}}{\left(1-h_{i}^{2} \cdot p_{i}\right)}}$

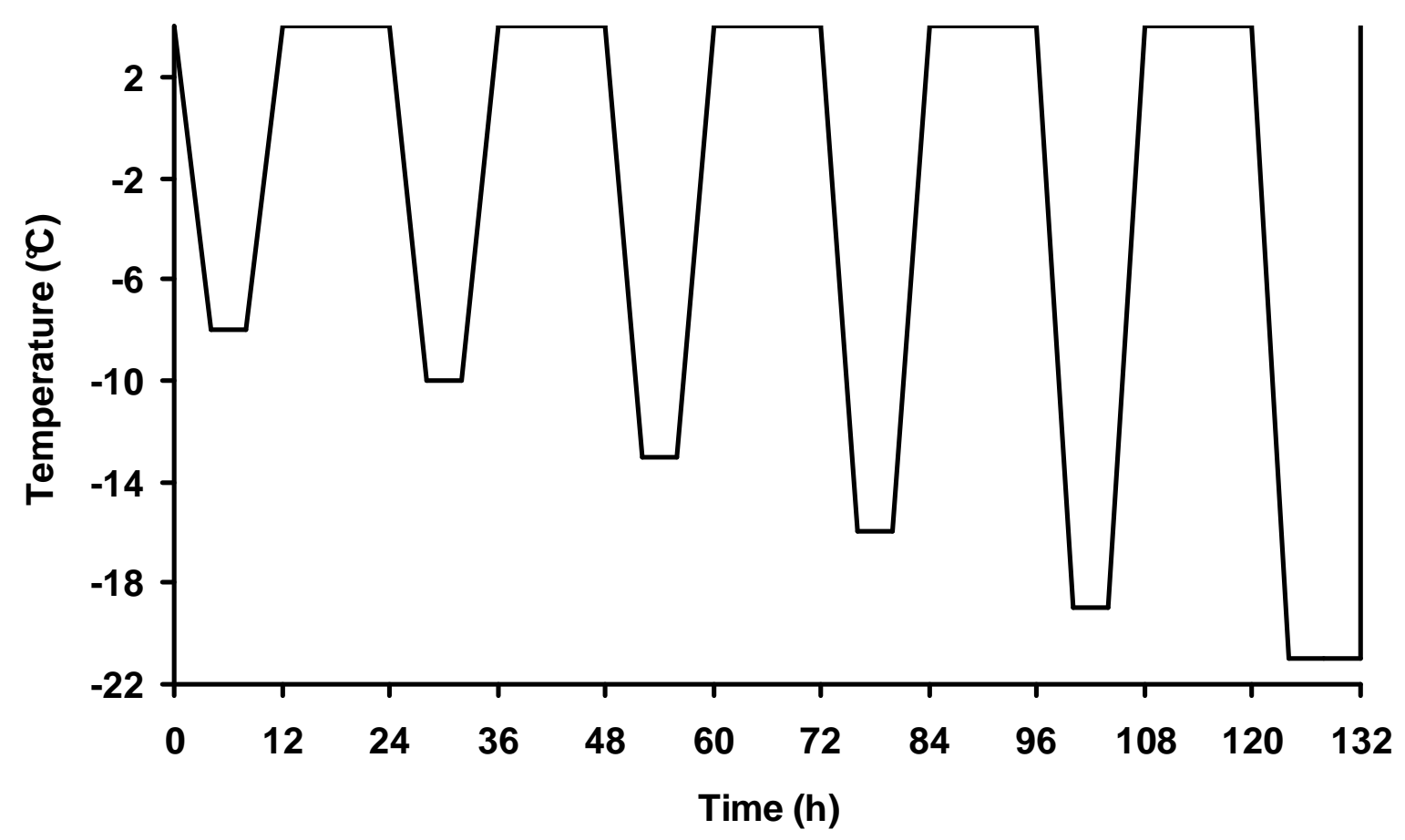

Figure III-1. Temperature profile of the artificial frost test. 


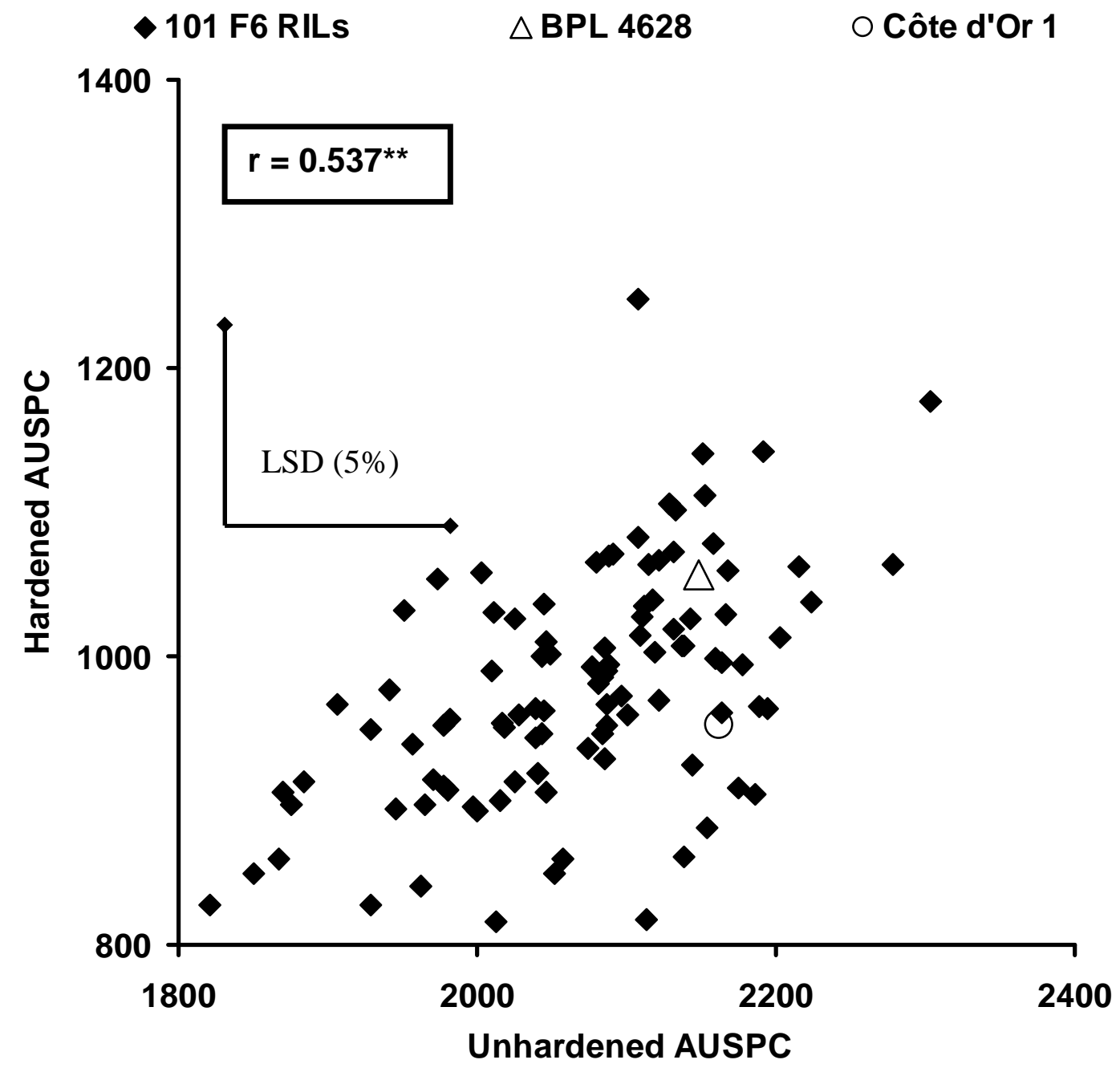

Figure III-2. Correlation between hardened AUSPC and unhardened AUSPC. 
$\bullet 101$ F6 RILs $\triangle$ BPL $4628 \quad$ OCôte d'Or1

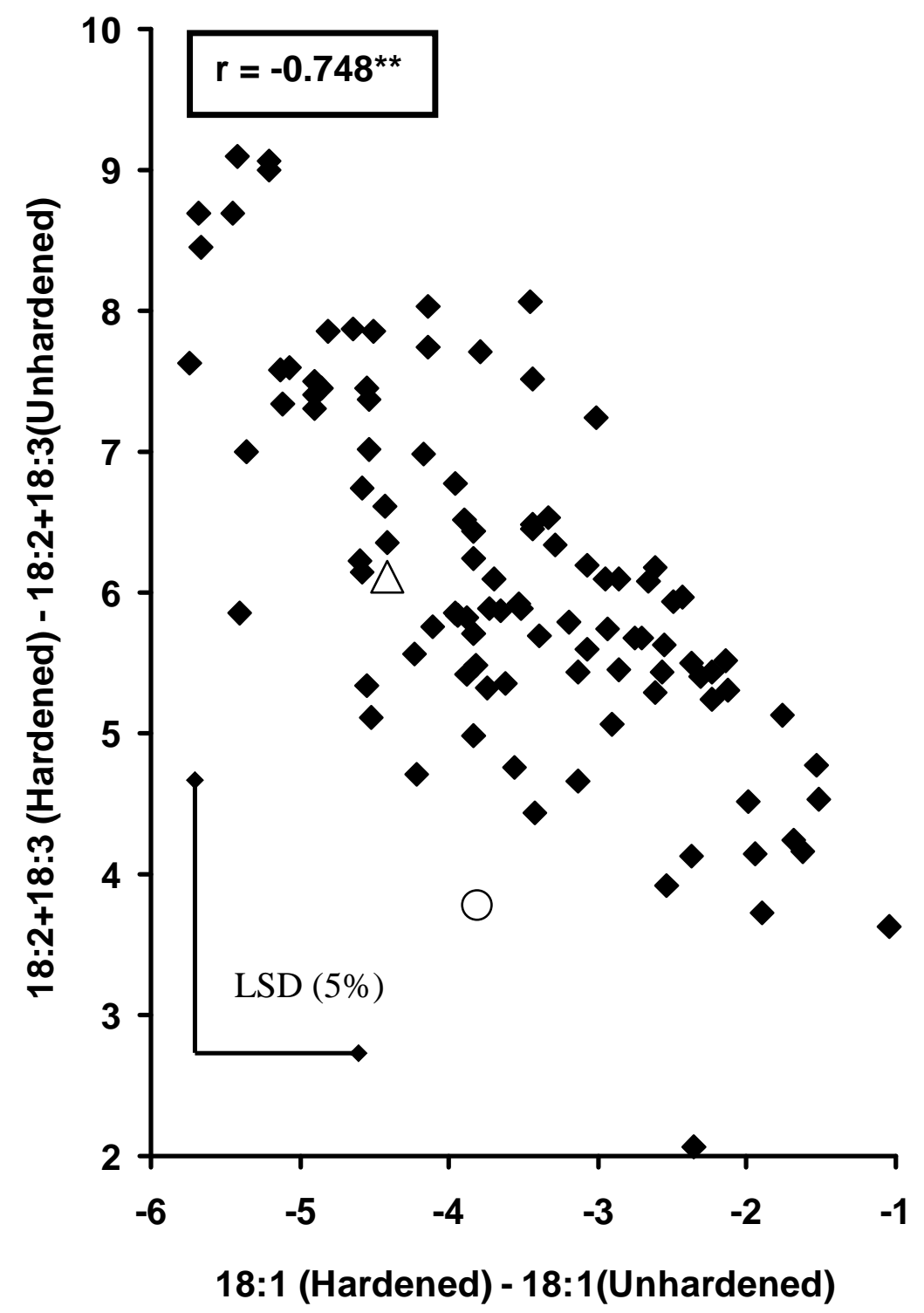

Figure III-3. Correlation between changes in 18:1 and 18:2+18:3 due to hardening. 


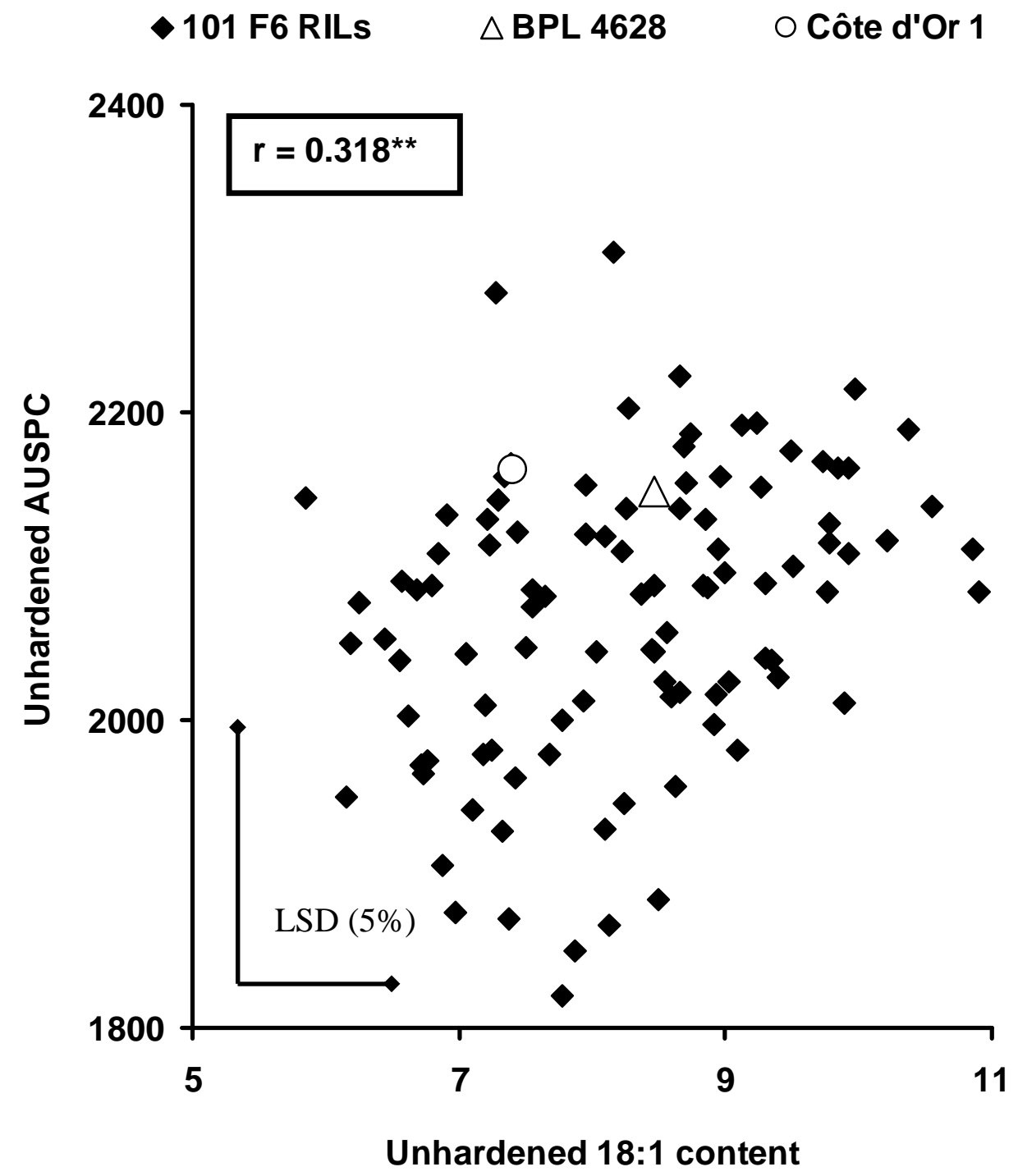

Figure III-4. Correlation between 18:1 content in unhardened leaves and unhardened AUSPC. 

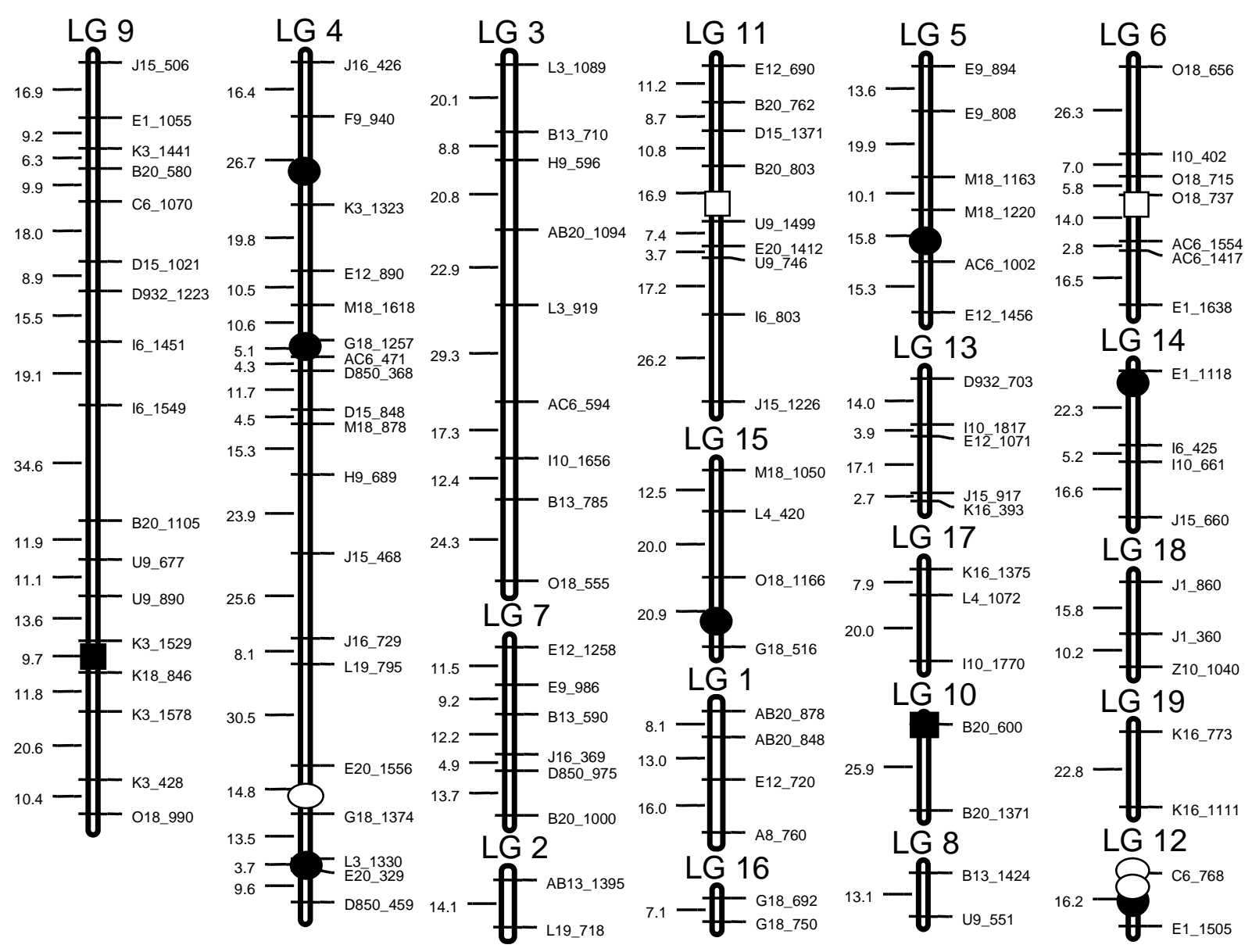

- Hardened frost tolerance Unhardened frost tolerance

Fattv acid content

Fatty acid changes

Figure III-5. Genetic linkage map of faba bean based on $101 \mathrm{~F} 6$ recombinant inbred lines derived from the cross between Côte d'Or 1 and BPL 4628. Quantitative trait loci (QTL) mapping for hardened and unhardened frost tolerance, fatty acid content, and fatty acid changes due to hardening.

\section{References}

Arbaoui, M., C. Balko, and W. Link. 2007. Study of faba bean (Vicia faba L.) winterhardiness and development of screening methods for frost tolerance. (Submitted to Crop Sci).

Badaruddin,M., and D.W. Meyer. 2001. Factors modifying frost tolerance of legume species. Crop Sci. 41:1911-1916.

Bates, L.S., R.P. Waldren, and J.D. Teare. 1973. Rapid determination of free proline for water stress studies. Plant Soil. 39:205-207. 
Beavis, W.D. 1998. QTL Analyses: Power, Precision, and Accuracy. Pp. 145-162. In Molecular dissection of complex traits. Paterson, A.H. (ed.) CRC Press, Boca Raton / New York.

Bouchez, A., F. Hospital, M. Causse, A. Gallais, and A. Charcosset. 2002. Markerassisted introgression of favourable alleles at quantitative trait loci between maize elite lines. Genetics. 162:1945-1959.

Chandrasekar, V., R.K. Sairam, and G.C. Srivastava. 2000. Physiological and biochemical responses of hexaploid and tetraploid wheat to drought stress. J. Agron. Crop Sci. 185:219-227.

Cyril, J., G.L. Powell, R.R. Duncan, and W.V. Baird. 2002. Changes in membrane polar lipid fatty acids of Seashore Paspalum in response to low temperature exposure. Crop Sci. 42:2031-2037.

Davis, D.L., and W.B. Gilbert. 1970. Winter hardiness and changes in soluble protein fractions of bermudgrass. Crop Sci. 10:7-9.

Duc, G., and F. PetitJean. 1995. Study of inheritance of freezing tolerance in Vicia faba L. 2nd European Conference on Grain Legumes. Copenhagen. Denmark. 11-15 july 1995.

Dörffling, K., H. Dörffling, G. Lesselich, E. Luck, C. Zimmermann, G. Melz, and H.U. Jürgens. 1997. Heritable improvement of frost tolerance in winter wheat by in vitro-selection of hydroxyproline-resistant proline overproducing mutants. Euphytica. 93:1-10.

Fridman, E., T. Pleban, and D. Zamir. 2000. A recombination hotspot delimits a wildspecies quantitative trait locus for tomato sugar content to $484 \mathrm{bp}$ within an invertase gene. Proc. Natl. Acad. Sci. USA. 97:4718-4723.

Haldane, J.B.S. 1919. The combination of linkage values, and the calculation of distance between the loci and the linked factor. J. Genet. 8:299-309.

Herzog, H. 1987. A quantitative method to assess freezing resistance in faba beans. J. Agron. Crop Sci. 158:195-204.

Hospital, F., and A. Charcosset. 1997. Marker assisted introgression of quantitative trait loci. Genetics. 147:1469-1485. 
Jansen, R.C., and P. Stam. 1994. High resolution of quantitative traits into multiple loci via interval mapping. Genetics. 136:1447-1455.

Knapp, S. 1998. Marker assisted selection as a strategy for increasing the probability of selecting superior genotypes. Crop Sci. 38:1164-1174.

Lande, R., and R. Thompson. 1990. Efficiency of marker assisted selection in the improvement of quantitative traits. Genetics. 124:743-756.

Lander, E.S., P. Green, J. Abrahamson, A. Barlow, M.J. Daly, S.E. Lincoln, and L. Newburg. 1987. MAPMAKER: an interaction computer program for constructing genetic linkage maps of experimental and natural populations. Genomics. $1: 174-181$.

Lange, C., and J. Whittaker. 2001. On prediction of genetic values in marker-assisted selection. Genetics. 159:1375-1381.

Levitt, J. 1980. Responses of Plants to Environmental Stresses. Vol. 1. Academic Press, New York. 166-222.

McKenzie, J.S., R. Paquin, and S.H. Duke. 1988. Cold and Heat Tolerance. In: Alfalfa and Alfalfa Improvement. Hanson, A.A., Barnes, D.K., and Hill, R.R., Jr (eds.) Agronomy monograph No. 29, ASA, WI, pp. 259-302.

Melchinger, A.E., H.F. Utz, and C.C. Schön. 1998. Quantitative trait locus (QTL) mapping using different testers and independent population samples in maize reveals low power of QTL detection and large bias in estimates of QTL effects. Genetics. 149:383-403.

Melchinger, A.E., H.F. Utz, and C.C. Schön. QTL analyses of complex traits with cross validation, bootstrapping, and other biometric methods. Euphytica. 137:111.

Micic, Z., V. Hahn, E. Bauer, C.C. Schön, S.J. Knapp, S. Tang, and A.E. Melchinger. 2004. QTL mapping of Sclerotinia midstalk-rot resistance in sunflower. Theor. Appl. Genet. 109:1474-1484.

Moreau, L., A. Charcosset, F. Hospital, and A. Gallais. 1998. Marker assisted selection efficiency in populations of finite size. Genetics. 148:1353-1365. 
Ohno, R., S. Takumi, and C. Nakamura. 2001. Expression of cold-responsive Lt-Cor gene and development of freezing tolerance during cold acclimation in wheat (Triticum aestivum L.). J. Exp. Bot. 52:2367-2374.

Openshaw, S., and E. Frascaroli. 1997. QTL detection and marker assisted selection for complex traits in maize. $52^{\text {nd }}$ Annual Corn and Sorghum Industry Research Conference. ASTA, Washington, DC, pp. 44-53.

Petcu, E., and M. Terbea. 1995. Proline content and the conductivity test as screening methods for frost tolerance of winter wheat. Bulg. J. Plant Physiol. $21: 3-11$.

Pollock, C.J. 1986. Fructans and the metabolism of sucrose in vascular plants. New Phytol. 104:1-24.

Rizza, F., C. Crosatti, A.M. Stanca, and L. Cativelli. 1994. Studies for assessing the influence of hardening on cold tolerance of barley genotypes. Euphytica. 75:131-138.

Romagosa, I., F. Han, S.E. Ullrich, P.M. Hayes, and D.M. Wesenberg. 1999. Verification of yield QTL through realized molecular marker-assisted selection responses in a barley cross. Molecular Breeding. 5:143-152.

Román B., A.M. Torres, D. Rubiales, J.I. Cubero, and Z. Satovic. 2002. Mapping of quantitative trait loci controlling broomrape (Orobanche crenata Forsk.) resistance in faba bean (Vicia faba L.). Genome. 45:1057-1063.

Román B., Z. Satovic, C.M. Avila, D. Rubiales, M.T. Moreno, and A.M. Torres. 2003. Locating genes associated with Aschochyta fabae resistance in Vicia faba. Aust. J. Agric. Res. 54:85-90.

Santoiani, C.S., J.A. Tognetti, H.G. Pontis, and G.L. Salerno. 1993. Sucrose and fructan metabolism in wheat roots at chilling temperature. Physiol. Plant. 87:8488.

Schön, C.C., H.F. Utz, S. Groh, B. Truberg, S. Openshaw, and A.E. Melchinger. 2004. Quantitative Trait Locus mapping based on resampling in a vast maize testcross experiment and its relevance to quantitative genetics for complex traits. Genetics. 167:485-498. 
Shaner, G., and R.E. Finney. 1977. The effect of nitrogen fertilization on the expression of slow-mildewing resistance in Knox wheat. Phytopathology. 67:1051-1056.

Steel, R.G.D., and J.H. Torrie. 1981. Principles and Procedures of Statistics. International student editions. Mcgraw-Hill, New York.

Stone, J.M., J.P. Palta, J.B. Bamberg, L.S. Weiss, and J.F. Harbage. 1993. Inheritance of freezing resistance in tuber bearing Solanum species: evidence for independent genetic control of non-acclimated freezing tolerance and cold acclimation capacity. Proc. Natl. Acad. Sci. USA. 90:7869-7873.

Thies, W. 1971. Schnelle und einfache Analysen der Fettsäurezusammensetzung in einzelnen Raps-Kotyledonen. I. Gaschromatographische und papierchromatographische Methode. Z. Pflanzenzüchtung. 65:181-202.

Thomashow, M.F. 1999. Plant cold acclimation: freezing tolerance genes and regulatory mechanisms. Annu. Rev. Plant Physiol. Plant Mol. 50:571-599.

Torres, A.M., N.F. Weeden, and A. Martin. 1993. Linkage among isozyme, RFLP and RAPD markers in Vicia faba. Theor. Appl. Genet. 85:937-945.

Troll, W., and J. Lindsley. 1955. A photometric method for the determination of proline. J. Biol. Chem. 215:655-660.

Utz, H.F. 1991. A computer program for statistical analysis of plant breeding experiments. Institute of Plant Breeding, Seed Science and Population Genetics. University of Hohenheim.

Utz, H.F., and A.E. Melchinger. 1994. Comparison of different approaches to interval mapping of quantitative trait loci. In: Biometrics in Plant Breeding: Applications of Molecular Markers. Proceedings of the Ninth Meeting of the EUCARPIA Section Biometrics in Plant Breeding, edited by J.W. Van Ooijen and J. Jansen. July 6-8, 1994, pp. 195-204, CPRO-DLO, Wageningen, The Netherlands.

Utz, H.F., and A.E. Melchinger. 1996. PLABQTL: a program for composite interval mapping of QTL. J. Quant. Trait Loci 2. 1:1-5.

Utz, H.F., A.E. Melchinger, and C.C. Schön. 2000. Bias and sampling error of the estimated proportion of genotypic variance explained by quantitative trait loci 
determined from experimental data in maize using cross validation and validation with independent samples. Genetics. 154:1839-1849.

Vales, M.I., C.C. Schön, F. Capettini, X.M. Chen, A.E. Corey, D.E. Mather, C.C. Mundt, K.L. Richardson, J.S. Sandoval-Islas, H.F. Utz, and P.M. Hayes. 2005. Effect of population size on the estimation of QTL: a test using resistance to barley strip rust. Theor. Appl. Genet. Original paper.

Williams, J.G.K., A.R. Kubelik, K.J. Livak, J.A. Rafalski, and S.V. Tingey. 1990. DNA polymorphisms amplified by arbitrary primers are useful as genetic markers. Nucleic Acids Res. 18:6531-6535.

Wei, H., A.L. Dhanaraj, R. Arora, L.J. Rowland, Y. Fu, and L. Sun. 2005. Identification of cold acclimation-responsive Rhododendron genes for lipid metabolism, membrane transport and lignin biosynthesis: importance of moderately abundant ESTs in genomic studies. Plant Cell Environ. 29:558-570.

Yousef, G.G., and J.A. Juvik. 2001. Comparison of phenotypic and marker-assisted selection for quantitative traits in sweet corn. Crop Sci. 136:1457-1468. 


\section{Study on heterosis for frost tolerance in faba bean (Vicia faba L.)}

M. Arbaoui and W. Link (prepared for Plant Breeding)

\section{Abstract}

Faba bean (Vicia faba L.) is a partial allogamous crop. It is mostly grown as spring crop in North Europe, although superiority of winter bean was proven. In order to improve its winter-hardiness, heterosis for frost tolerance was studied to eventually make use of it. Four parental lines were used to construct a half diallel. Significant heterosis was observed; especially among crosses of the two European lines with the exotic line and the spring line. The average of the F2-hybrids was as expected near to the mean of mid-parents and F1-hybrids. The cross between the two European lines showed no heterosis. It suggested that these two lines shared most favourable alleles for frost tolerance.

\section{Introduction}

In most North and Central European countries, faba bean (Vicia faba L.) is mainly grown as spring crop because of the limited winter-hardiness of the present winter cultivars. Motivated by the superiority of winter types as compared to spring types for protein and grain yield, breeding programs were initiated to improve faba bean winter-hardiness.

The actual winter-hardiness of a plant depends on its resistance to biotic winter stress, and adverse abiotic conditions such as freezing temperatures (Davidson and Reid, 1987; Herzog, 1987a; Badaruddin and Meyer, 2001). Because of the unpredictability of natural freezing temperatures, methods were developed to test for frost tolerance under controlled conditions (Herzog, 1987b; Herzog, 1989; Rizza et al., 1994; Duc and PetitJean, 1995; Badaruddin and Meyer, 2001; Arbaoui et al., 2007a). Among other methods, visual scoring of freezing injuries was commonly used because it is non-destructive and it is as reliable as e.g. chlorophyll and conductivity measurements (Herzog, 1987b; Herzog and Olszewski, 1998). These methods were mainly applied to leaves because they are directly exposed to freezing and low non-freezing temperatures. In faba bean (Arbaoui et al., 2007a) and in other plant species (Rizza et al, 1994; Petcu and Terbea, 1995), frost tolerance was found to be a main component of winter-hardiness. 
Faba bean is a partial allogamous crop with an average of $50 \%$ of cross-pollination (Link et al., 1994). Therefore, the existing cultivars are mainly synthetics or populations. In these cultivars, on average half of the plants are expected to be noninbred. A cultivar's phenotypic trait expression is thus a combined result of trait expression at different levels of heterozygosity.

The objective of this study was (1) to determine mid-parent heterosis for frost tolerance and (2) to suggest a strategy to make an optimum use of heterosis in faba bean breeding.

\section{Material and Methods}

Plant Materials

Four parental inbred lines were used: Côte d'Or 1 (Cor1; derived from the winterhardy French landrace Côte d'Or), BPL 4628 ("Bean Pure Line", Chinese inbred line from the ICARDA germplasm collection), Wibo/1 (derived from the cultivar Wibo bred by Littman), and Kristall/25 (K25; derived from the spring cultivar Kristall). Manual crosses among these lines were performed in isolating cages. From the six possible F1-hybrids, F2-hybrids were also produced by controlled self-fertilization (Link, 1990).

Artificial frost tests

Thus, the four parental lines, the six F1-hybrids, the six F2-hybrids, and six checks (European winter beans) were tested in artificial frost conditions to assess their frost tolerance. The growing conditions to produce hardened seedlings, the method of testing, and the scoring of freezing injuries on leaves and stems were performed as described by Arbaoui et al. (2007a). Accordingly, the "Area Under Symptom Progress Curve" (AUSPC) was calculated and considered as the expression of the genotype's frost tolerance; low values indicating high frost tolerance. All genotypes were tested in five experiments. Each experiment was laid out as randomized complete block design with four replicates; one replicate of a genotype being one pot with four plants.

Analyses of variance were performed excluding the checks in order to test significance among parental lines, F1-hybrids, and F2-hybrids. These analyses were performed by PLABSTAT (Utz, 1991). To test GCA and SCA for significance, PZ14 
software was used (Utz, 1992). Mid-parent heterosis was assessed as follows: F1 minus midparental values, and tested for significance by mid-parents vs F1 (Table 1).

\section{Results}

Performance and analysis of variance

On average, $\mathrm{F} 1$-hybrids were more frost tolerant (AUSPC $=897$ scoreunit ${ }^{\circ} \mathrm{C} h$ ) than their parental lines $\left(\right.$ AUSPC $=990$ scoreunit ${ }^{\circ} \mathrm{h}$ ); F2-hybrids being near to the mean of F1 and parents (Figure 1). Heterosis for frost tolerance increased significantly with the decrease of mid-parent frost tolerance $(r=-0.815)$. In case of the cross between Côte d'Or/1 and Wibo/1, being the cross with the lowest parental mean for AUSPC (highest tolerance), F1- and F2-hybrids were not significantly more frost tolerant than their parental mean. On the other hand, hybrids of these two lines with BPL 4628 were more frost tolerant than mid-parents. None of the hybrids was better performing than the most frost tolerant parent Côte d'Or/1 (its AUSPC was 810 scoreunit ${ }^{\circ} \mathrm{C} h$ ). Analyses of variance showed significant differences among parents, F1-hybrids, and F2-hybrids but also between the parental means and the corresponding F1-hybrids. On the other hand, the generation mean of F2 was as expected not different from the average of parental means and F1 (Table 1).

Among the checks, Hiverna/2 was the most frost tolerant genotype (838 scoreunit ${ }^{\circ} \mathrm{C}$ h) and HBNr 40652 the most sensitive (1340 scoreunit ${ }^{\circ} \mathrm{h}$ ).

\section{Estimates of combining abilities}

The results showed significant GCA at $p=5 \%$ and SCA at $p=10 \%$ for frost tolerance (Table 1). The GCA effects (in scoreunit ${ }^{\circ} \mathrm{C}$ h) for Côte d'Or/1, Wibo/1, BPL 4628, and K25 were $-34,-20,-53$, and +107, respectively. Thus, BPL 4628, in spite of being the third best line, inherited a stronger (the highest) favourable effect than it realized itself.

The higher variance component observed for GCA (4134.3) than for SCA (823.6) was reflected by the very high correlation between the actual F1-hybrids' performance and their predicted performance based on GCA alone (i.e., without use of SCA, $r=0.967)$. Similar findings were observed by Duc and PetitJean (1995). 


\section{Discussion}

Significant and very marked increase of frost tolerance was observed from the parents across F2 to the F1-hybrids. Nevertheless, this heterosis cannot be fully exploited in faba bean breeding because no hybrid cultivars are commercially available due to the unstable CMS systems. The realized alternatives, synthetic and population cultivars, make use of about half of the total heterosis due to the limited degree of cross-fertilization.

Although highest heterosis occurred in the three crosses with K25 (spring bean; Figure 1), these hybrids were less performing than the further hybrids. The seemingly absence of heterosis in the cross Côte d'Or/1 x Wibo/1 suggested that these two lines shared most favourable alleles for this trait. Since both lines are European winter types this may be true. The most promising cross was Côte d'Or/1 x BPL 4628 (Duc and Petitjean, 1995), because it showed marked heterosis in spite of both parents being rather frost tolerant. Likely, these parents are complementary for frost tolerance genes. Given the exotic provenience of BPL 4628 this cross promises marked segregation and transgression. Indeed, a population of 101 inbred lines from this cross showed several QTL associated with frost tolerance and contained 27 lines with significantly higher frost tolerance than the better parent Côte d'Or/1 (Arbaoui et al., 2007b).

Since overwintering is a precondition for grain yield and since both traits show marked heterosis, winter faba beans make higher use of heterosis and suffer more from inbreeding depression than spring beans. Thus, the optimum number of components for a synthetic cultivar in spring bean $(4<\mathrm{N}<6$; Link and Ederer, 1993) should be reconsidered with a higher weight for winter bean given to the aspect of heterosis. The optimum number of inbred lines to establish a synthetic cultivar in winter faba bean should be rather eight to ten.

\section{Acknowledgements}

This work was supported by funds from the commission of the European Communities, specific Research Program Quality of Life and Management of Living Resources, QLK5-2001-02307. It does not necessarily reflect its views and in no way anticipates the Commissions' future policy in this area. The authors thank NPZLembke Company for their financial contribution. 
Table IV-1. Analysis of variance of combining ability for frost tolerance in $6 \mathrm{~F} 1$ and F2-hybrids of faba bean.

\begin{tabular}{lrrrc}
\hline Sources of variation & DF & \multicolumn{1}{c}{ SS } & \multicolumn{1}{c}{ MS } & F \\
\hline Experiments & 4 & 1205050.30 & 301262.60 & $69.62^{* *}$ \\
Entries & 17 & 978363.25 & 57550.78 & $13.30^{* *}$ \\
F2-hybrids & 5 & 257763.01 & 51552.60 & $7.89^{* *}$ \\
F2 vs. (Mid-parents and F1) & 1 & 163.43 & 163.43 & 0.03 \\
(Mid-parents and F1-hybrids) & 11 & 720436.81 & 65494.26 & $20.57^{* *}$ \\
$\quad$ Mid-parents & 5 & 422768.88 & 84553.78 & $55.62^{* *}$ \\
$\quad$ Mid-parents vs. F1 & 1 & 130049.52 & 130049.50 & $29.96^{* *}$ \\
$\quad$ F1-hybrids & 5 & 167618.41 & 33523.68 & $7.26^{* *}$ \\
$\quad$ GCA & 3 & 156742.39 & 52247.46 & $4.37^{*}$ \\
SCA & 2 & 10876.02 & 5438.01 & $4.12+$ \\
F2-hybrids x Experiments & 20 & 130758.09 & 6537.90 & 1.51 \\
F2 vs (Mid-parents and F1) x Exp & 4 & 23372.61 & 5843.15 & 1.35 \\
(Mid-parents and F1) x Exp & 44 & 140129.04 & 3184.75 & 0.74 \\
$\quad$ Mid-parents x Exp & 20 & 30405.04 & 1520.25 & 0.35 \\
$\quad$ Mid-parents vs. F1 x Exp & 4 & 17362.57 & 4340.64 & 1.00 \\
$\quad$ F1 x Experiments & 20 & 92361.43 & 4618.07 & 1.07 \\
$\quad$ GCA x Experiments & 12 & 81800.67 & 6816.72 & $5.16^{*}$ \\
$\quad$ SCA x Experiments & 8 & 10560.76 & 1320.09 & 0.00 \\
Error & 68 & 294259.73 & 4327.35 & \\
\hline
\end{tabular}

$+,{ }^{*},{ }^{*}$, significant at $10 \%, 5 \%, 1 \%$ respectively. 


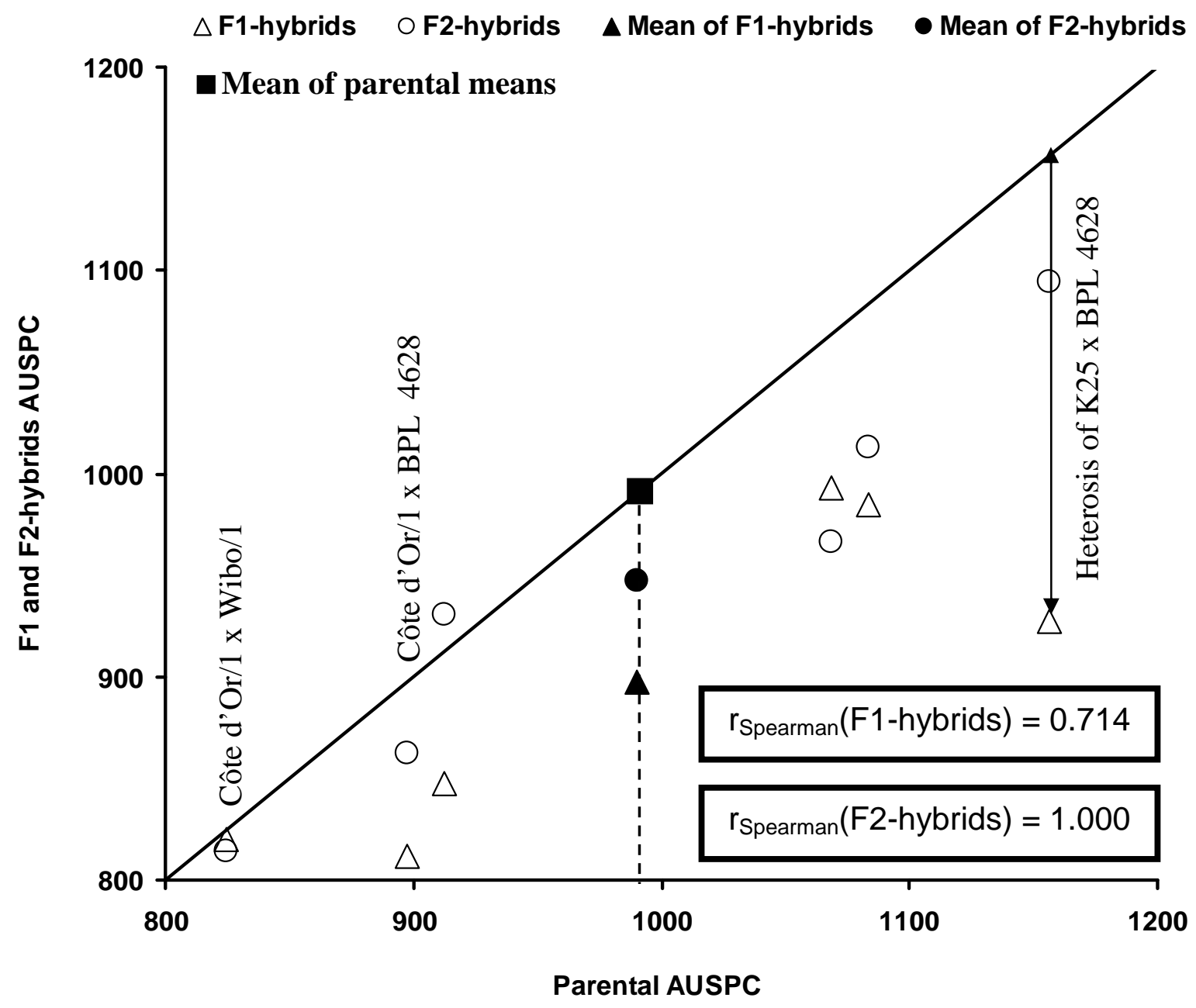

Figure IV-1. Frost tolerance of mid-parents and their respective F1 and F2-hybrids.

\section{References}

Arbaoui, M., C. Balko, and W. Link. 2007a. Study of faba bean (Vicia faba L.) winterhardiness and development of screening methods for frost tolerance. (Submitted to Crop Sci).

Arbaoui, M., A.M. Torres, and W. Link. 2007b. QTL mapping of frost tolerance and physiological traits on faba bean (Vicia faba L.).

Badaruddin,M., and D.W. Meyer. 2001. Factors modifying frost tolerance of legume species. Crop Sci. 41:1911-1916.

Davidson, N.J., and J.B. Reid. 1987. The influence of hardening and waterlogging on the frost resistance of subalpine eucalypts. Aust. J. bot. 35:91-101. 
Duc, G., and F. PetitJean. 1995. Study of inheritance of freezing tolerance in Vicia faba L. 2nd European Conference on Grain Legumes. Copenhagen. Denmark. 11-15 july 1995.

Herzog, H. 1987a. Freezing resistance and development of faba beans as affected by ambient temperatures, soil moisture and variety. J. Agron. Crop Sci. 159:90100.

Herzog, H. 1987b. A quantitative method to assess freezing resistance in faba beans. J. Agron. Crop Sci. 158:195-204.

Herzog, H. 1989. Influence of pre-hardening duration and dehardening temperatures on varietal freezing resistance in faba beans (Vicia faba L.). Agronomie (Paris). 9:55-61.

Herzog H., and A. Olszewski. 1998. A rapid method for measuring freezing resistance in crop plants. J. Agron. Crop Sci. 181:71-79.

Link, W. 1990. Autofertility and rate of cross-fertilization: Crucial characters for breeding synthetic varieties in faba beans (Vicia faba L.). Theor. Appl. Genet. 79:713-717.

Link, W. and W. Ederer. 1993. The concept of varietal ability for partially allogamous crops. Plant Breeding 110:1- 8.

Link, W. et al. 1994. Genotypic and environmental variation for degree of crossfertilization in faba bean. Crop Sci. 34:960-964.

Petcu E., and M. Terbea .1995. Proline content and the conductivity test as screening methods for frost tolerance of winter wheat. Bulg. J. Plant Physiol. 21:3-11.

Rizza, F., C. Crosatti, A.M. Stanca, and L. Cativelli. 1994. Studies for assessing the influence of hardening on cold tolerance of barley genotypes. Euphytica. $75: 131-138$.

Utz, H.F. 1991. A computer program for statistical analysis of plant breeding experiments. Institute of Plant Breeding, Seed Science and Population Genetics. University of Hohenheim.

Utz, H.F. 1992. PZ14. Programm zur Verrechnung dialleler Kreuzungsanlagen über Orte und Jahre. Institute of Plant Breeding, Seed Science and Population genetics, University of Hohenheim, Stuttgart. 


\section{General discussion}

In a research program on faba bean breeding for winter-hardiness, five European winter beans with high overwintering were identified (Chapter I); among them Bulldog/1 (5.27 scoreunit) and Hiverna/2 (5.82 scoreunit). In artificial frost tests (Chapter I), Hiverna/2 displayed high frost tolerance (1058.50 scoreunit ${ }^{\circ} \mathrm{h}$ ) albeit it did not (as all other genotypes), fully survive the last step of testing (showing then a mean symptom score of 2.70). Indeed, based on an experiment of re-growth of plants after testing them in artificial frost tests (details not given), the score threshold for a hardened plant to survive was found to be 2.10 scoreunit. Using this threshold score, the LT50 of Hiverna/2 was identified at the fifth temperature step $\left(-19{ }^{\circ} \mathrm{C}\right)$ of the test. For genotypes with higher frost tolerance (e.g. F7-95), the LT50 was between the fifth $\left(-19^{\circ} \mathrm{C}\right)$ and the sixth $\left(-22^{\circ} \mathrm{C}\right)$ step; and between the third $\left(-13^{\circ} \mathrm{C}\right)$ and fourth $\left(-16{ }^{\circ} \mathrm{C}\right)$ step for spring beans (Figure I-1).

The significant GxE interactions for overwintering and grain yield (Table I-1) enabled further investigations on the specific and/or general adaptation of these genotypes to the studied environments. Such an analysis was performed as "additive main effect and multiplicative interaction" (AMMI) decomposition. The AMMI approach combines an analysis of variance of genotype and environment main effects with a principal component analysis of the GxE interactions into a unified approach (Gauch and Zobel, 1996). In this analysis, the environments Gleisdorf in 2004 and Jõgeva in 2005 were excluded because these winters were too harsh and the variance among genotypes was rather low. The three spring beans were as well excluded because there was no variation in their performance (no survival) across all environments. Thus, for overwintering and grain yield, the two first principal component axes were significant. They explained $55 \%$ of the GxE interactions variability of overwintering and $78 \%$ of grain yield. The results showed higher stability of European beans than experimental beans for overwintering and grain yield. Among European beans, Hiverna/2 displayed the highest main effect for overwintering and a high general adaptation to the ten environments (Figure 1). For grain yield, this line was good performing and displayed the highest stability over all nine environments; apparently thanks to its high overwintering (Figure 2). Moreover, based on a selection index (details not shown) developed to combine overwintering and grain yield performance, Hiverna/2 was the best performing among inbred lines; GöttWAB and Karl being the 
two best over all genotypes. Significant progress for frost tolerance and ultimately for winter-hardiness is expected from the cross between the experimental line F7-(Côte d'Or/1 x BPL 4628)-95 with Hiverna/2 and Bulldog/1 (Chapter I). Regression analysis of mean winter-hardiness on frost tolerance (hardened and unhardened AUSPC-AFT and AUSPC-PFT) and on physiological responses to hardening (proline and fatty acid content, and membrane stability) showed that only hardened AUSPC-AFT was explaining significant parts of overwintering variance (details not shown). Still, it is clear that these proposed crosses are not the final solution for the frost tolerance and ultimately the winter-hardiness improvement. Indeed, the material tested in this experiment was sampled from a large, but limited, set of winter bean genotypes. There are further European winter-hardy genotypes (e.g. L977/88/S1wn, L979/S1/1/1sn, Bourdon) and exotic frost tolerant beans (e.g. ILB 506, ILB 523, ILB 87; Olsewski, 1995) that could as well contribute to the genetic improvement of winter-hardiness.

The absence of heterosis for frost tolerance observed in the cross of two European inbred lines (Côte d'Or/1 and Wibo/1; Chapter IV) is not a good argument in favour of reasonable genetic diversity for frost tolerance in such highly tolerant European material, including Hiverna, Karl, etc. Rather the contrary may be true. This assumption would have been more valid if more than two European lines were tested in the diallel experiment. Moreover, the lack of reciprocal crosses prevents conclusions on the maternal effect for frost tolerance.

In order to keep the good field based performance of Hiverna/2 (or any other proven European type of winter bean) and to improve solely its frost tolerance, introgression by back-crosses of exotic favourable alleles originated from BPL 4628 could be achieved. Indeed, based on a recombinant inbred line population derived from the cross between Côte d'Or/1 and BPL 4628, Arbaoui et al. (Chapter III) detected four putative QTL for frost tolerance that were equally inherited from both parents. If similar allelic composition of Hiverna/2 and Côte d'Or/1 was assumed for frost tolerance because of their common European background and if only the two detected QTL favourably inherited from BPL 4628 were introgressed to Hiverna/2 (or any other proven European type of winter bean), a gain on mean frost tolerance of 52 scoreunit ${ }^{\complement} \mathrm{C} h$ would be expected on this material. Based on the regression analysis of winter-hardiness on frost tolerance, this gain in frost tolerance was translated into a corresponding gain in overwintering. Thus, across all environments, with the given 
frost tolerance gain, overwintering would increase by 0.34 scoreunit. In intermediate winter environments, with this frost tolerance gain, a marked and maybe decisive gain in overwintering is expected due to the higher slope of regression in such environments (Chapter I; e.g. a gain of 0.84 scoreunit at Göttingen in 2006).

Moreover, in the RIL population (Chapter III), the mean frost tolerance across hardened and unhardened plants of four lines (F7-95, F7-73, F7-94 and F7-33) exceeded the performance of Côte d'Or/1 by more than 180 scoreunit ${ }^{\circ} \mathrm{C}$ h. In addition to these two detected QTL, there were obviously other non detected QTL originated from BPL 4628. If detected, these QTL could be used to further improve frost tolerance and thus increase overwintering of any European lines by 1.10 scoreunit on average across all environments and even more in intermediate winters (e.g., by 2.90 scoreunit at Göttingen in 2006). Further material with favourable "exotic" alleles like BPL 4628 should be sought.

Based on phenotypic data, physiological traits related to frost tolerance such as leaf proline, fatty acid, and sugar content could also be used to select for higher frost tolerance. Based on the material of Chapter I, single regression analyses of hardened frost tolerance on all physiological traits revealed that proline content, unhardened oleic acid content, its changes and linoleic+linolenic acid changes due to hardening were significant. After multiple regression, only proline content was significant and was therefore included in the regression model. Based on the RIL, significant correlations were also found between frost tolerance and unhardened oleic acid $\left(r=0.318^{\star *}\right.$; Chapter III), proline content $\left(r=-0.351^{* *}\right.$; Figure 3$)$ and sugar content $\left(r=-0.360^{\star *}\right.$; Figure 4). Similarly an accumulation of proline and soluble sugar content in leaf cells due to hardening significantly increased faba bean frost tolerance. This result corroborated the important role of these physiological responses in the frost tolerance expression.

The QTL analyses for proline content detected one putative marker loci with a low LOD score (2.06) which was congruent (interval distance of $4 \mathrm{cM}$ ) with a marker loci associated with the unhardened frost tolerance $\left(B 20 \_803\right.$, LOD $\left.=3.83\right)$. This QTL might therefore be involved in the inheritance of both traits. In case of soluble sugars, two putative QTL were detected on LG 4 and 7 that explained $17.20 \%$ of the genotypic variance of the trait. None of these QTL was linked to frost tolerance loci 
and might solely influence the soluble sugar content. However, cross-validation revealed that the bias in the genotypic variance explained was high (Appendix I).

European type $\square$ Exotic type $\Delta$ Mild winters $\Delta$ Intermediate winters $\Delta$ Harsh winters

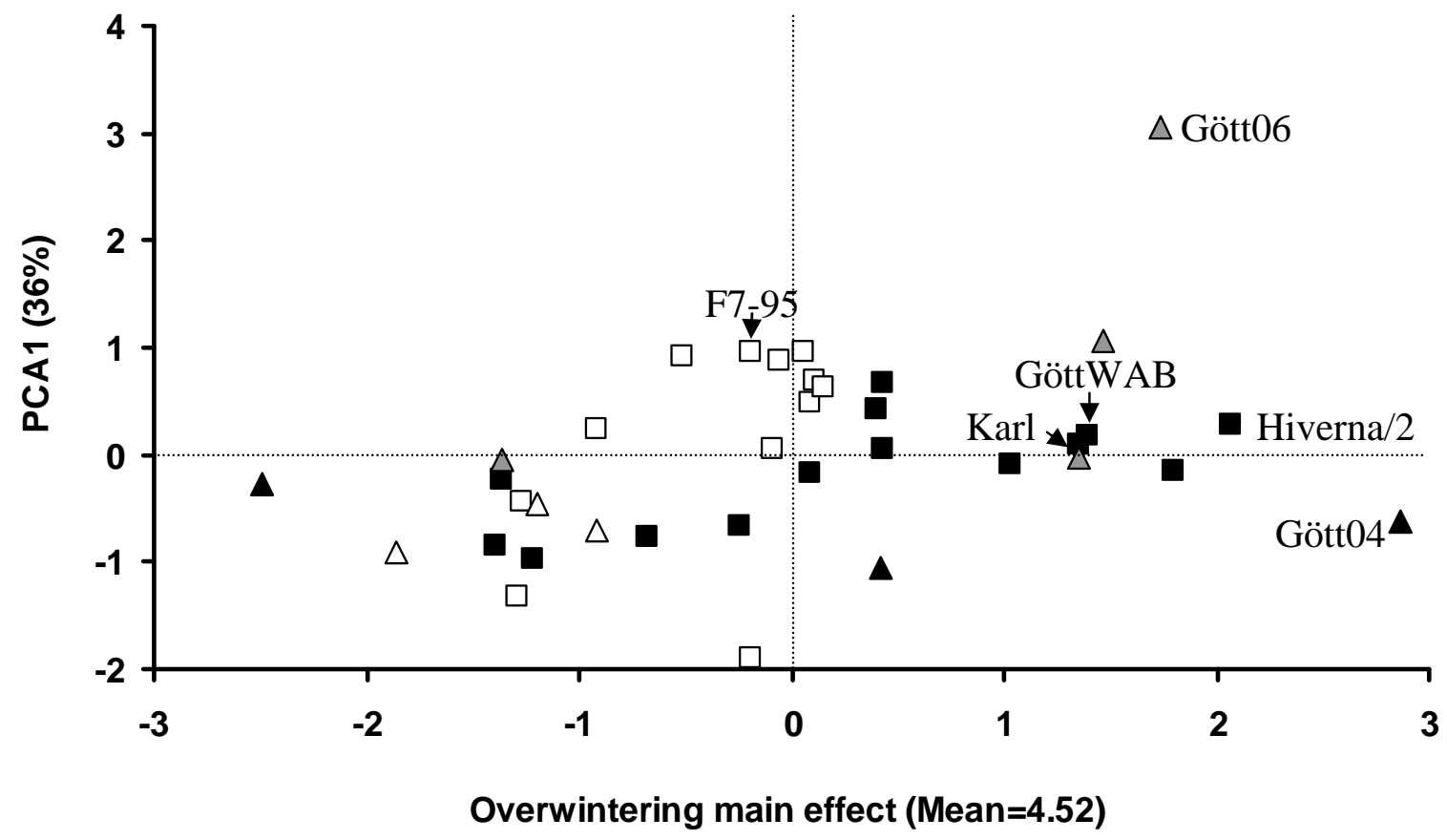

Figure GD-1. AMMI biplot of the first principal component axis and the overwintering main effect (scoreunit) of 26 genotypes and 10 environments.

European type $\square$ Exotic type $\Delta$ Mild winters $\Delta$ Intermediate winters $\Delta$ Harsh winters

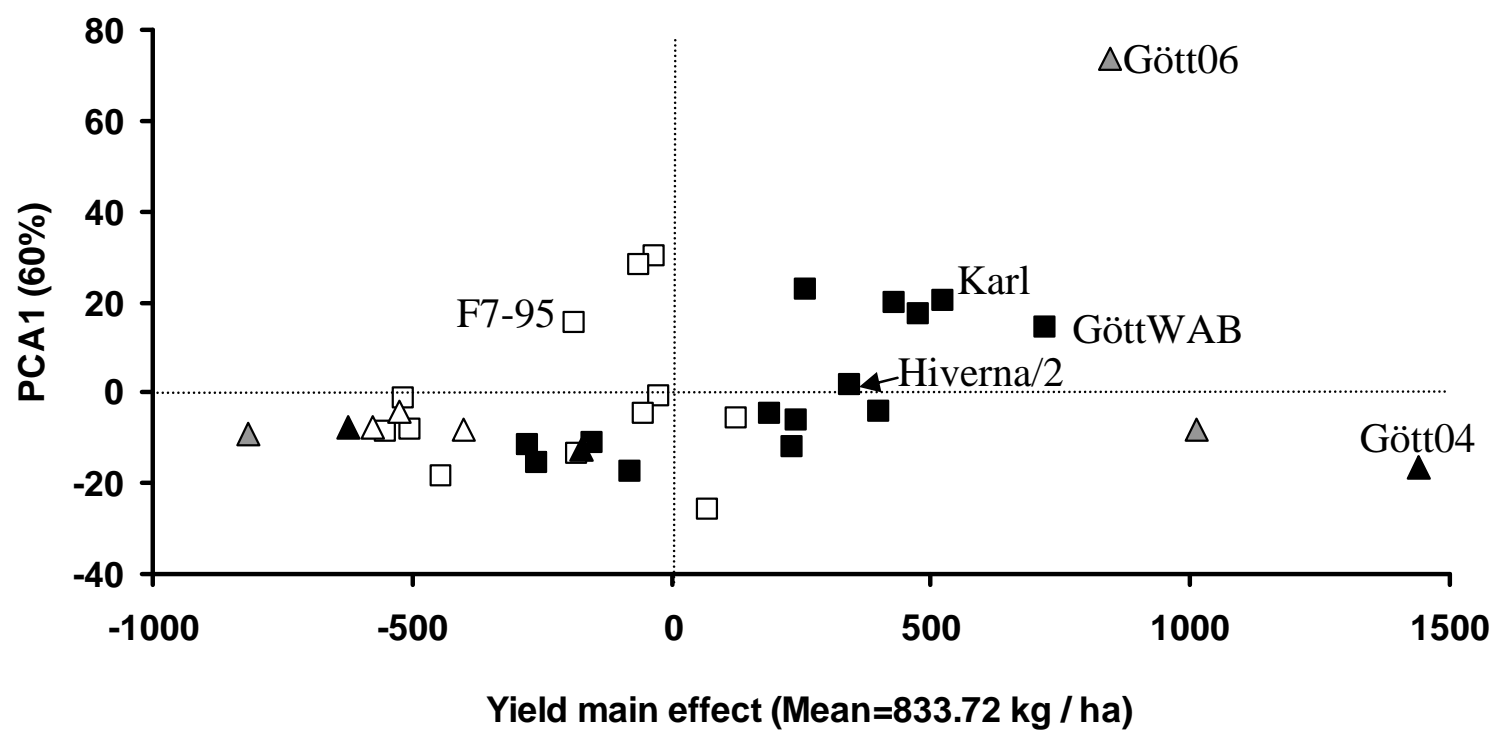

Figure GD-2. AMMI biplot of the first principal component axis and the grain yield main effect (scoreunit) of 26 genotypes and 9 environments. 


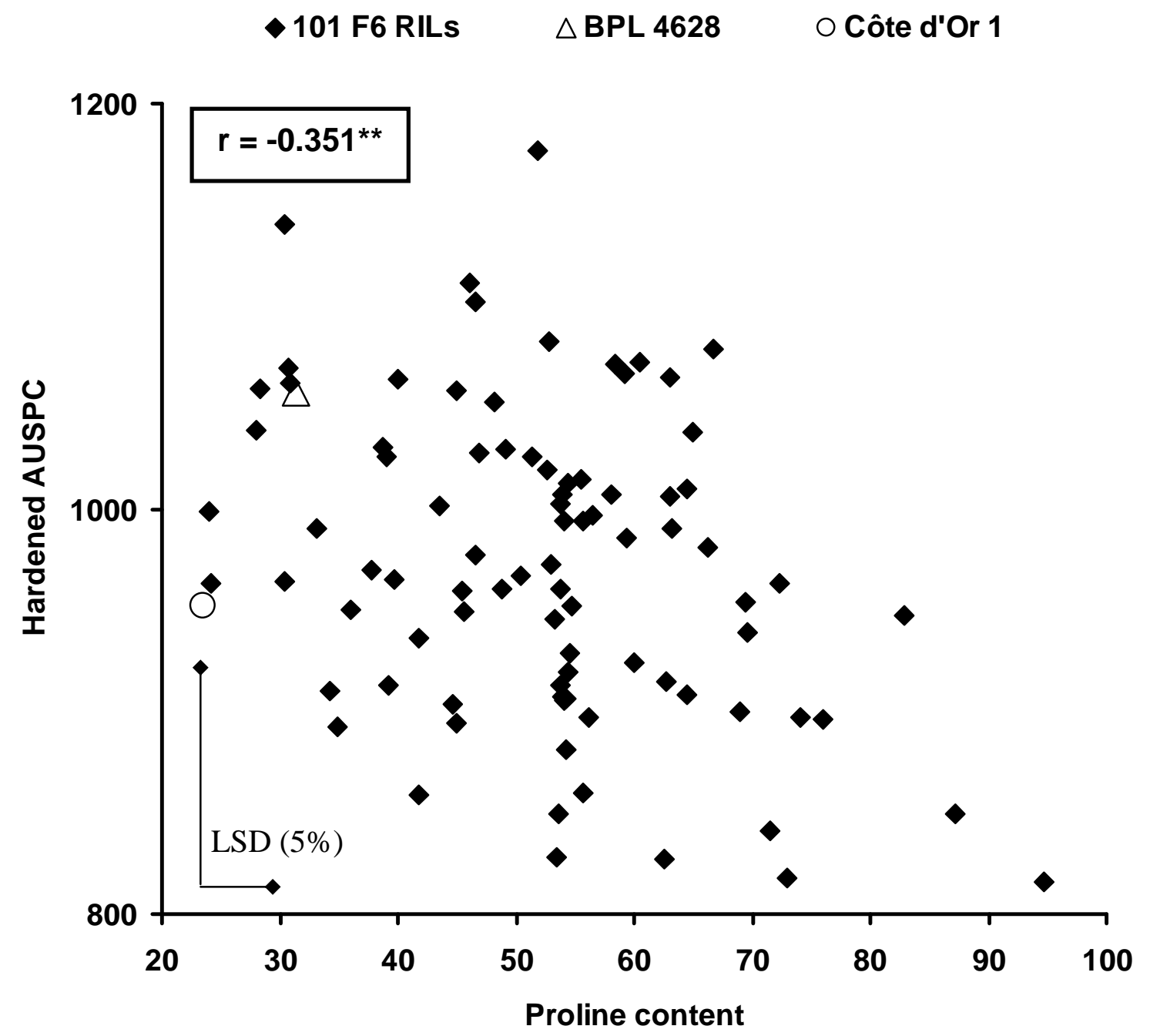

Figure GD-3. Correlation between proline (content $\mu \mathrm{mol} \mathrm{g}^{-1}$ dry matter) after hardening and hardened frost tolerance (scoreunit ${ }^{\circ} \mathrm{C} h$ ) on the 87 recombinant inbred lines and the parental lines. 


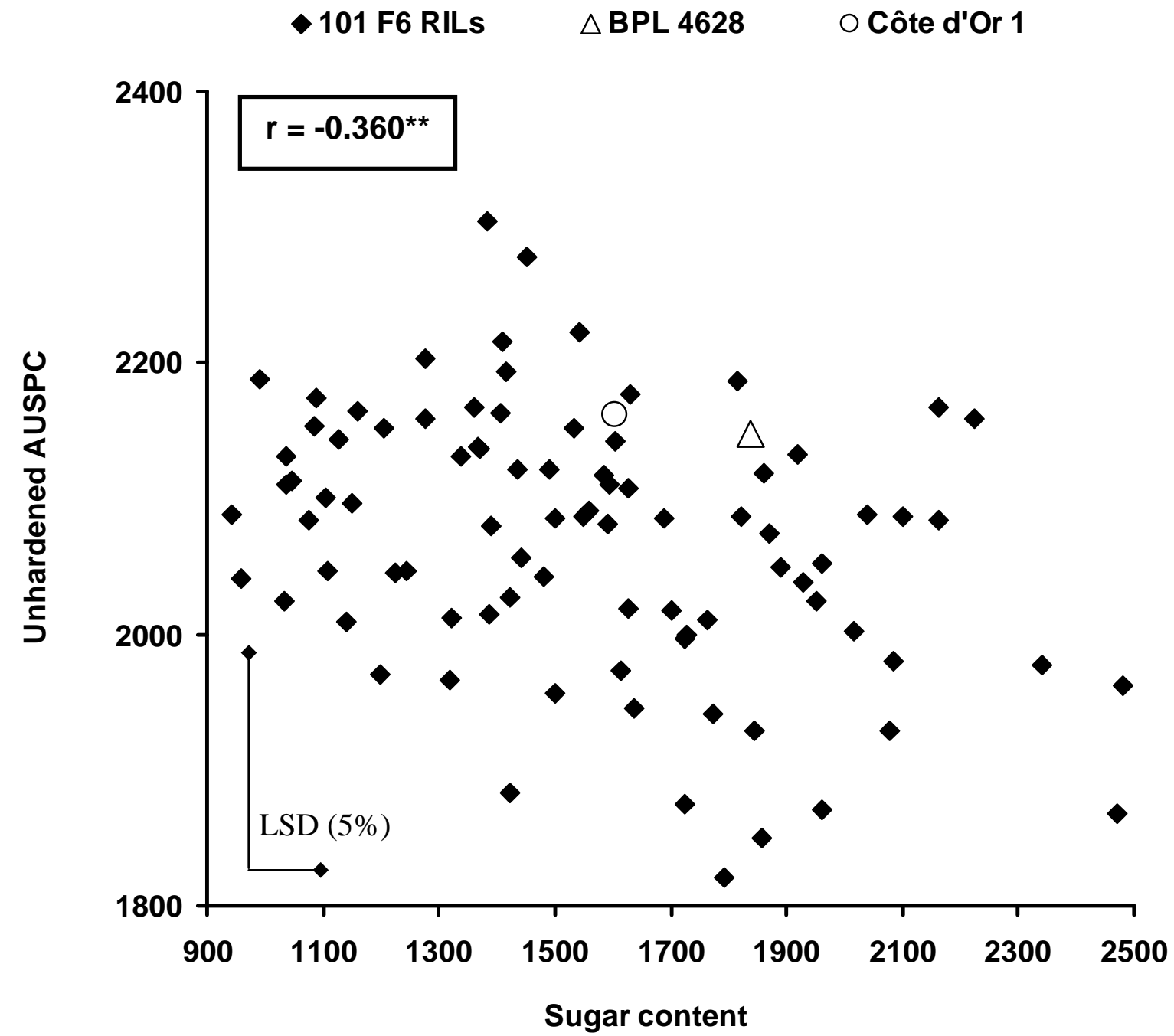

Figure GD-4. Correlation between sugar content ( $\mu \mathrm{mol}$ eq glucose $\mathrm{g}^{-1}$ dry matter) after hardening and hardened frost tolerance (scoreunit ${ }^{\circ} \mathrm{C}$ ) on the 87 recombinant inbred lines and the parental lines.

In marker assisted selection, the selection on a secondary trait is probably not necessary since any detected QTL of this secondary trait that influences as well the main trait should be detected as QTL of the main trait on the same or tightly linked to this position. Thus, for hardened and unhardened frost tolerance, the relative efficiency of pure and combined marker assisted selection over the classical phenotypic selection was determined using the Lande and Thompson formula (1990). In order to assess the relative efficiency of pure MAS for the frost tolerance across both treatments, an index of selection based on marker data and on phenotypic data was constructed. From these indices and the response to selection (Baker, 1986), a more generalized formula of the RE of MAS was developed (Appendix II) and applied in the present study. It appeared that pure MAS would be 
still less efficient than CPS (RE = 0.60; Appendix II, cf. Example); mainly due to the low genotypic variance explained by the putative QTL. 


\section{Appendix I. QTL analyses with LOD threshold of 1.5}

Parameters associated with putative quantitative trait loci (QTL) for frost tolerance and fatty acid composition in both treatments assessed from genotypic and phenotypic data of 101 F6 recombinant inbred lines from the cross Côte d'Or 1 x BPL 4628.

\begin{tabular}{|c|c|c|c|c|c|c|c|c|c|c|}
\hline \multicolumn{3}{|c|}{ Phenotypic traits } & $\begin{array}{l}\text { Linkage } \\
\text { Groups } \\
\text { (LG) }\end{array}$ & Marker & $\begin{array}{c}\text { Position } \\
\text { on LG } \\
\text { (cM) }\end{array}$ & $\begin{array}{l}\text { LOD at } \\
\text { QTL } \\
\text { position }\end{array}$ & $\begin{array}{c}\text { Additive } \\
\text { effect }\end{array}$ & $\begin{array}{l}\text { Phenotypic } \\
\text { variance } \\
\text { explained }\end{array}$ & $\begin{array}{l}p_{D S} \\
\%\end{array}$ & $\begin{array}{l}\mathrm{p}_{\text {TS }} \\
\%\end{array}$ \\
\hline & \multirow{12}{*}{ 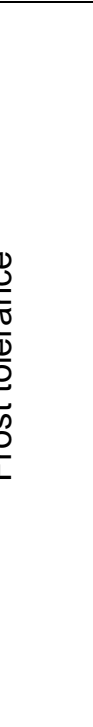 } & \multirow{4}{*}{$\begin{array}{l}\frac{0}{d} \\
\frac{1}{d} \\
\frac{0}{0} \\
\frac{0}{5} \\
\frac{5}{J}\end{array}$} & LG11 & B20_803 & 54 & 3.83 & -33.52 & 16.30 & \multirow{4}{*}{47.50} & \multirow{4}{*}{13.91} \\
\hline & & & LG6 & O18_737 & 48 & 3.54 & 32.77 & 14.40 & & \\
\hline & & & LG14 & $16 \_425$ & 32 & 2.91 & -29.79 & 12.90 & & \\
\hline & & & LG4 & E20_329 & 302 & 1.57 & -26.15 & 9.70 & & \\
\hline & & \multirow{8}{*}{ 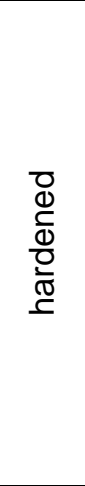 } & LG10 & B20_600 & 0 & 4.54 & -32.13 & 22.20 & \multirow{8}{*}{67.10} & \multirow{8}{*}{7.97} \\
\hline & & & LG9 & K3_1529 & 216 & 4.28 & 31.14 & 20.00 & & \\
\hline & & & LG13 & J15_917 & 42 & 3.24 & -28.23 & 18.10 & & \\
\hline & & & LG7 & B13_590 & 30 & 2.44 & -26.33 & 12.60 & & \\
\hline & & & LG3 & I10_1656 & 150 & 2.39 & 25.71 & 12.10 & & \\
\hline & & & LG14 & I10_661 & 38 & 1.83 & -22.62 & 10.20 & & \\
\hline & & & LG11 & E12_690 & 0 & 1.78 & -17.53 & 7.70 & & \\
\hline & & & LG11 & B20_803 & 54 & 1.83 & -16.96 & 7.60 & & \\
\hline \multirow{19}{*}{ 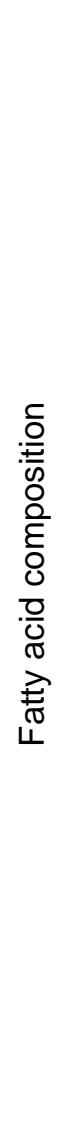 } & \multirow{19}{*}{ 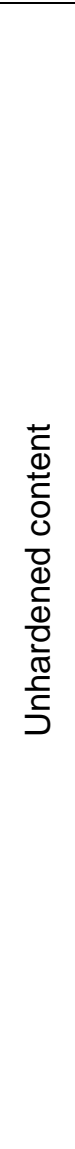 } & \multirow{6}{*}{$16: 0$} & LG15 & O18_1166 & 60 & 4.05 & -0.21 & 16.10 & \multirow{6}{*}{46.80} & \multirow{6}{*}{4.02} \\
\hline & & & LG3 & B13_710 & 22 & 1.78 & -0.17 & 12.40 & & \\
\hline & & & LG4 & E20_1556 & 272 & 2.29 & 0.17 & 12.00 & & \\
\hline & & & LG5 & AC6_1002 & 70 & 1.91 & -0.15 & 9.50 & & \\
\hline & & & LG4 & F9_940 & 38 & 2.61 & -0.18 & 8.30 & & \\
\hline & & & LG16 & G18_692 & 0 & 1.51 & 0.10 & 4.80 & & \\
\hline & & \multirow{4}{*}{$16: 1$} & LG7 & D850_975 & 56 & 2.39 & 0.08 & 12.40 & \multirow{4}{*}{39.70} & \multirow{4}{*}{16.34} \\
\hline & & & LG3 & B13_785 & 188 & 2.73 & 0.07 & 12.00 & & \\
\hline & & & LG19 & K16_773 & 26 & 2.17 & -0.07 & 9.90 & & \\
\hline & & & LG9 & D932_1223 & 94 & 1.88 & -0.06 & 8.30 & & \\
\hline & & \multirow{3}{*}{$18: 0$} & LG4 & G18_1257 & 106 & 6.08 & -0.05 & 22.10 & \multirow{3}{*}{38.70} & \multirow{3}{*}{8.47} \\
\hline & & & LG13 & E12_1071 & 26 & 2.22 & -0.03 & 5.30 & & \\
\hline & & & LG9 & 16_1451 & 116 & 2.37 & -0.03 & 5.20 & & \\
\hline & & \multirow{6}{*}{$18: 1$} & LG12 & C6_768 & 4 & 7.66 & 0.64 & 37.00 & \multirow{6}{*}{67.10} & \multirow{6}{*}{42.69} \\
\hline & & & LG4 & L3_1330 & 290 & 6.11 & -0.41 & 23.40 & & \\
\hline & & & LG14 & E1_1118 & 8 & 3.52 & 0.43 & 17.30 & & \\
\hline & & & LG4 & J15_468 & 208 & 2.20 & -0.26 & 10.30 & & \\
\hline & & & LG3 & I10_1656 & 158 & 1.76 & -0.23 & 8.70 & & \\
\hline & & & LG5 & M18_1220 & 66 & 2.06 & 0.23 & 7.90 & & \\
\hline
\end{tabular}




\begin{tabular}{|c|c|c|c|c|c|c|c|c|c|c|}
\hline & & & LG5 & M18_1220 & 64 & 3.56 & -0.58 & 15.30 & & \\
\hline & & & LG7 & E12_1258 & 2 & 2.69 & 0.48 & 12.60 & & \\
\hline & & & LG12 & C6_768 & 0 & 2.20 & -0.43 & 12.20 & & \\
\hline & $\stackrel{\frac{\Phi}{\sigma}}{0}$ & $18: 2$ & LG4 & L19_795 & 220 & 2.99 & 0.45 & 11.00 & 48.90 & 1.71 \\
\hline & 0 & & LG4 & F9_940 & 52 & 1.84 & -0.40 & 10.30 & & \\
\hline & $\frac{5}{0}$ & & LG7 & D850_975 & 56 & 1.96 & -0.40 & 9.70 & & \\
\hline & $\underset{\frac{\bar{\sigma}}{c}}{\tau}$ & & LG3 & AB20_1094 & 70 & 2.13 & 0.47 & 7.70 & & \\
\hline & & 10.0 & LG4 & F9_940 & 42 & 3.59 & 0.80 & 12.80 & ת 20 & ק? \\
\hline & & 10.0 & LG15 & O18_1166 & 50 & 2.64 & 0.66 & 9.80 & $2<.00$ & $-4 . \angle S$ \\
\hline & & $18: 4$ & LG6 & I10_402 & 40 & 4.03 & -0.15 & 9.10 & 16.40 & 3.81 \\
\hline & & $16 \cdot 0$ & LG3 & B13_710 & 26 & 2.75 & -0.18 & 10.10 & 1870 & 1228 \\
\hline & & 10.0 & LG4 & E20_1556 & 272 & 2.37 & 0.18 & 9.00 & 10.10 & $1<.<0$ \\
\hline & & & LG3 & AB20_1094 & 86 & 2.88 & -0.07 & 13.80 & & \\
\hline & & $16: 1$ & LG17 & K16_1375 & 0 & 3.21 & 0.06 & 13.40 & 25.80 & -1.33 \\
\hline & & & LG3 & B13_710 & 26 & 1.66 & 0.05 & 6.40 & & \\
\hline & & $18: 0$ & LG4 & E12_890 & 88 & 1.57 & -0.04 & 8.70 & 8.70 & -1.46 \\
\hline & & & LG4 & G18_1374 & 284 & 3.15 & -0.39 & 13.30 & 151 & 101 \\
\hline 든 & & 10.1 & LG6 & O18_737 & 50 & 1.63 & 0.24 & 5.60 & 10.10 & -1.01 \\
\hline क & & & LG9 & D15_1021 & 74 & 3.25 & 0.45 & 14.50 & & \\
\hline $\bar{E}$ & $\stackrel{\bar{\Phi}}{\Xi}$ & & LG3 & L3_1089 & 0 & 2.36 & 0.34 & 10.50 & & \\
\hline$\frac{0}{0}$ & 욱 & $18: 2$ & LG2 & AB13_1395 & 2 & 2.40 & -0.30 & 7.10 & 32.90 & -1.23 \\
\hline$\underset{\pi}{\pi}$ & $\stackrel{\Phi}{\frac{\Phi}{\alpha}}$ & & LG19 & K16_773 & 0 & 1.73 & -0.28 & 7.00 & & \\
\hline$\stackrel{+}{\mathscr{\sigma}}$ & 훙 & & LG4 & E20_1556 & 264 & 2.00 & -0.26 & 4.60 & & \\
\hline & & & LG11 & U9_1499 & 56 & 2.15 & 0.57 & 13.20 & & \\
\hline & & & LG5 & M18_1163 & 46 & 2.15 & 0.58 & 13.10 & & \\
\hline & & $18: 3$ & LG11 & B20_762 & 22 & 3.78 & -0.53 & 12.40 & 35.90 & -7.02 \\
\hline & & & LG6 & AC6_1554 & 64 & 1.94 & -0.36 & 7.10 & & \\
\hline & & & LG4 & J16_426 & 0 & 2.03 & 0.35 & 6.50 & & \\
\hline & & & LG16 & G18_692 & 2 & 3.80 & 0.14 & 13.90 & & \\
\hline & & 10.1 & LG3 & AB20_1094 & 70 & 1.57 & -0.15 & 9.70 & 0730 & 66 \\
\hline & & 10.4 & LG17 & K16_1375 & 4 & 2.18 & 0.11 & 8.20 & 87.50 & -0.05 \\
\hline & & & LG19 & K16_773 & 0 & 1.54 & 0.10 & 7.40 & & \\
\hline & & & Lg12 & C6_768 & 2 & 2.24 & 0.16 & 10.50 & & \\
\hline &.$\subsetneq \frac{.}{\bar{C}}$ & 10.0 & LG4 & M18_878 & 132 & 2.34 & 0.16 & 9.80 & 20 & $5 ? 2$ \\
\hline & 흠 & 10.0 & LG9 & K3_428 & 258 & 2.17 & -0.15 & 9.00 & 13.30 & 0.23 \\
\hline & 웅 & & LG15 & L4_420 & 28 & 1.62 & 0.16 & 7.60 & & \\
\hline & $\frac{0}{\partial}$ & $16 \cdot 1$ & LG9 & K3_428 & 256 & 2.47 & 0.08 & 10.40 & 2750 & 916 \\
\hline & $\mathscr{8}$ & 10.1 & LG4 & J15_468 & 198 & 2.28 & 0.09 & 8.00 & 27.00 & 9.10 \\
\hline & $\underset{\mathcal{D}}{\mathcal{C}}$ & $10 \cdot 0$ & LG4 & D15_848 & 124 & 2.47 & 0.04 & 6.60 & 600 & 207 \\
\hline & & 10.0 & LG18 & J1_860 & 16 & 2.79 & 0.02 & 1.00 & 0.00 & -0.01 \\
\hline
\end{tabular}




\begin{tabular}{|c|c|c|c|c|c|c|c|c|c|c|}
\hline \multirow{12}{*}{ 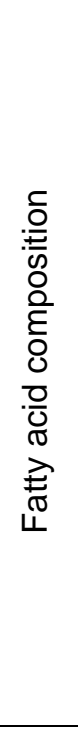 } & \multirow{12}{*}{ 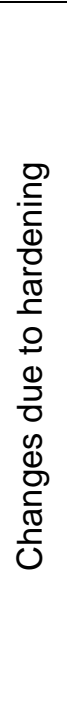 } & \multirow{4}{*}{$18: 1$} & LG12 & C6_768 & 0 & 4.94 & -0.55 & 28.70 & \multirow{4}{*}{48.10} & \multirow{4}{*}{10.59} \\
\hline & & & LG5 & M18_1220 & 68 & 1.99 & -0.29 & 9.60 & & \\
\hline & & & LG4 & D850_368 & 118 & 1.78 & 0.29 & 8.30 & & \\
\hline & & & LG9 & $16 \_1451$ & 108 & 1.83 & -0.31 & 7.30 & & \\
\hline & & \multirow{3}{*}{$18: 2$} & LG12 & C6_768 & 6 & 4.56 & 0.76 & 17.50 & \multirow{3}{*}{41.50} & \multirow{3}{*}{-2.32} \\
\hline & & & LG4 & E20_1556 & 270 & 4.06 & -0.63 & 12.80 & & \\
\hline & & & LG9 & K3_428 & 256 & 2.18 & -0.43 & 8.40 & & \\
\hline & & \multirow{4}{*}{$18: 3$} & LG9 & K3_428 & 256 & 1.66 & 0.53 & 9.00 & \multirow{4}{*}{23.40} & \multirow{4}{*}{-5.35} \\
\hline & & & LG15 & O18_1166 & 56 & 2.41 & -0.61 & 7.60 & & \\
\hline & & & LG4 & M18_878 & 130 & 2.18 & -0.46 & 6.70 & & \\
\hline & & & LG4 & E20_329 & 302 & 1.93 & 0.43 & 5.50 & & \\
\hline & & $18: 4$ & NONE & & & & & & & \\
\hline & & & LG11 & U9_1499 & 58 & 2.06 & 4.97 & 10.80 & 8.90 & -1.44 \\
\hline & & LG3 & L3_1089 & 0 & 1.55 & 99.19 & 9.80 & \multirow{7}{*}{31.90} & \multirow{7}{*}{2.37} \\
\hline & & & LG4 & J16_426 & 14 & 1.66 & -117.37 & 9.50 & & \\
\hline & & & LG4 & AC6_471 & 108 & 4.57 & 147.04 & 18.11 & & \\
\hline & & & LG4 & L3_1330 & 290 & 1.64 & 75.34 & 6.30 & & \\
\hline & & & LG7 & E12_1258 & 0 & 5.26 & 150.39 & 21.11 & & \\
\hline & & & LG9 & D15_1021 & 70 & 2.11 & 61.44 & 4.30 & & \\
\hline & & & LG17 & K16_1375 & 8 & 1.62 & -100.91 & 10.40 & & \\
\hline
\end{tabular}

The additive effect was calculated as follows: Côte d'Or/1 - BPL 4928 


\section{Appendix II. Marker assisted selection}

With the development of molecular marker during the past 15 years, genetic linkage maps were developed to map quantitative trait loci (QTL) associated with important agronomic traits such as yield. The putative QTL detected explained a significant part of the phenotypic and genotypic variance of the trait under study.

Prospects of marker assisted selection (MAS) were assessed by calculating its relative efficiency $(\mathrm{RE})$ vs. the classical phenotypic selection (CPS) for one specific trait by:

Pure MAS vs. CPS, RE $=\sqrt{\frac{\mathrm{p}}{\mathrm{h}^{2}}}$ (Lande and Thompson, 1990).

Selection is rarely performed on a single trait, but more often on several traits simultaneously, which therefore implies the use of an index of selection. Moreover, the use of marker data associated with more than one agronomic trait would be very useful in MAS of multiple traits.

In this case, the RE formula of Lande and Thompson (1990) can not be applied since it is based on a single trait.

The objective of the present study was to develop the relative efficiency of pure MAS vs. CPS for multiple trait selection.

\section{Index of selection}

There are two types of index that should be developed; one for phenotypic based selection and one for molecular based selection. The ratio of their corresponding response to selection would represent the relative efficiency of pure MAS.

It was assumed that both indexes were constructed with independent (uncorrelated) traits and with therefore non-overlapping and unlinked QTL between and within traits. Based on the optimum selection indices of Smith (Baker, 1986), the index coefficients $b_{i}$ would correspond to $a_{i} \cdot h_{i}^{2}$. 


\section{Molecular Index}

Since in the case of molecular data, $h^{2}=1$, the index will be written as follows:

$I_{M}=a_{1} M_{1}+a_{2} M_{2}+\ldots+a_{m} M_{m}$

With $I_{M}$ being the index of selection based on molecular marker data, $a_{i}$ the economic value of the $m$ traits, and $M_{i}$ the $Q T L$ effect.

Phenotypic Index

In this case, the index of selection based on phenotypic data will be written as:

$\mathrm{I}_{\mathrm{P}}=\mathrm{h}^{2}{ }_{1} \mathrm{a}_{1} \mathrm{P}_{1}+\mathrm{h}^{2}{ }_{2} \mathrm{a}_{2} \mathrm{P}_{2}+\ldots+\mathrm{h}^{2}{ }_{\mathrm{m}} \mathrm{a}_{\mathrm{m}} \mathrm{P}_{\mathrm{m}}$

With $\mathrm{h}^{2}$ being the heritability of each single traits.

\section{Response to selection}

Molecular Index

In general, the response of selection based on an index is depending on the standard deviation of the phenotypic traits to be improved and on the correlation between the trait and the index. In our case, the response of the molecular base index will be then expressed by the standard deviation of the phenotypic index and its genotypic correlation to the molecular marker index:

$\mathrm{R}_{\mathrm{IM}}=\mathrm{i} \cdot \sigma_{\mathrm{IP}} \cdot \mathrm{r}\left(\mathrm{I}_{\mathrm{P}} ; \mathrm{I}_{\mathrm{M}}\right)$

With i the intensity of selection

$\sigma_{\mid}$the standard deviation of the phenotypic index

$r\left(I_{P ;} I_{M}\right)$ the correlation between molecular and phenotypic index.

And $\quad r\left(I_{P} ; I_{M}\right)=\frac{\operatorname{COV}\left(I_{P} ; I_{M}\right)}{\sigma_{I P} \cdot \sigma_{I M}}$

By replacing it in the equation (3), the response if molecular index selection becomes:

$\mathrm{R}_{\text {Im }}=\mathrm{i} \cdot \sigma_{I_{\mathrm{P}}} \cdot \frac{\operatorname{cov}\left(\mathrm{I}_{\mathrm{P}} ; \mathrm{I}_{\mathrm{M}}\right)}{\sigma_{\text {IP }} \cdot \sigma_{\text {IM }}}=\mathrm{i} \cdot \frac{\operatorname{cov}\left(\mathrm{I}_{\mathrm{P}} ; \mathrm{I}_{\mathrm{M}}\right)}{\sigma_{\text {IM }}}$ 
with $\operatorname{cov}\left(I_{P ;} I_{M}\right)=\frac{1}{m} \sum\left(I_{P i}-I_{P}\right) *\left(I_{M i}-I_{M}\right)$

$=\frac{1}{m} \sum\left(\left(h^{2}{ }_{1 i} a_{1 i} P_{1 i}+h^{2}{ }_{2 i} a_{2 i} P_{2 i}+\ldots+h^{2}{ }_{m i} a_{m i} P_{m i}\right)-\left(h^{2}{ }_{1} a_{1} P_{1}+h^{2}{ }_{2} a_{2} P_{2}+\ldots+h^{2}{ }_{m} a_{m} P_{m}\right)\right) *\left(\left(a_{1 i} M_{1 i}\right.\right.$

$\left.\left.+a_{2 i} M_{2 i}+\ldots+a_{m i} M_{m i}\right)-\left(a_{1} M_{1}+a_{2} M_{2}+\ldots+a_{m} M_{m}\right)\right)$

$=\frac{1}{m} \sum\left(\left(h^{2}{ }_{1 i} a_{1 i} P_{1 i}-h^{2}{ }_{1} a_{1} P_{1}\right)+\left(h^{2}{ }_{2 i} a_{2 i} P_{2 i}-h^{2}{ }_{2} a_{2} P_{2}\right)+\ldots+\left(h^{2}{ }_{m i} a_{m i} P_{m i}-h^{2}{ }_{m} a_{m} P_{m}\right)\right) *\left(\left(a_{1 i} M_{1 i}-\right.\right.$

$\left.\left.a_{1} M_{1}\right)+\left(a_{2 i} M_{2 i}-a_{2} M_{2}\right)+\ldots+\left(a_{m i} M_{m i}-a_{m} M_{m}\right)\right)$

$=a_{1} \operatorname{cov}_{g}\left(P_{1} ; M_{1}\right)+a_{2} \operatorname{cov}_{g}\left(P_{2} ; M_{2}\right)+\ldots+a_{m} \operatorname{cov}_{g}\left(P_{m} ; M_{m}\right)$

The heritability was kept with the phenotypic value to give its genotypic covariance with molecular marker data.

Moreover, since all $\mathrm{P}_{\mathrm{i}}$ traits were assumed to be independent, their corresponding molecular marker group had no common marker. Thus, $\operatorname{cov}_{g}\left(P_{1} ; M_{2}\right.$ or 3...m $)$ was 0 .

According to the correlation equation, the covariance between phenotypic and molecular marker data could be expressed as:

$\operatorname{cov}_{g}\left(P_{1} ; M_{1}\right)=r_{g}\left(P_{1} ; M_{1}\right) \cdot \sigma_{P_{1}} \cdot \sigma_{M_{1}}$

$={\sqrt{p_{1}}}_{1} \cdot \sigma_{P_{1}} \cdot \sigma_{M_{1}}$

$p$ being the genotypic variance of the trait explained by the group of marker data.

$\sigma_{P}$ and $\sigma_{M}$ being the standard deviation of the phenotypic trait data and QTL effect, respectively. Moreover, $\sigma_{M}$ could be taken as the mean square (MS) from the regression analysis performed by $P L A B Q T L$.

In order to complete the equation of the response of selection, the standard deviation of the molecular index should be assessed. Because all $\mathrm{P}_{\mathrm{i}}$ traits are independent, they do not share any QTL in common. Thus $\operatorname{cov}_{\mathrm{g}}\left(\mathrm{M}_{1} ; \mathrm{M}_{2}\right.$ or $\left.3 \ldots \mathrm{m}\right)$ was 0

$$
\begin{aligned}
& \sigma^{2}\left(I_{M}\right)=\sigma^{2}\left(a_{1} M_{1}+a_{2} M_{2}+\ldots+a_{m} M_{m}\right) \\
& =a^{2}{ }_{1} \sigma^{2}\left(M_{1}\right)+a^{2}{ }_{2} \sigma^{2}\left(M_{2}\right)+\ldots+a^{2}{ }_{m} \sigma^{2}\left(M_{m}\right)+2 a_{1} a_{2} \operatorname{cov}\left(M_{1} ; M_{2}\right)+\sum \sum 2 a_{i} a_{j} \operatorname{cov}(\ldots) \\
& =a^{2}{ }_{1} \sigma^{2}\left(M_{1}\right)+a^{2}{ }_{2} \sigma^{2}\left(M_{2}\right)+\ldots+a^{2}{ }_{m} \sigma^{2}\left(M_{m}\right)
\end{aligned}
$$

Which could then be generalised as:

$$
\sigma^{2}\left(I_{M}\right)=\sum_{i} a_{i}^{2} \cdot \sigma_{M i}^{2}
$$


Based on the generalisation of (5) and on (6), the response to selection from the multiple molecular index for $m$ traits could be assessed by:

$R_{I M}=i \cdot \frac{\sum_{i} a_{i} \cdot \sigma_{M i} \cdot \sigma_{i} \cdot \sqrt{p_{i}}}{\sqrt{\sum_{i} a_{i}^{2} \cdot \sigma_{M i}^{2}}}$

Based on the equation (7), if we assume only one trait, the response of the selection will be:

$R_{I M}=i \cdot \frac{a \cdot \sigma_{M} \cdot \sigma_{P} \cdot \sqrt{p}}{a \cdot \sigma_{M}}=i \cdot \sqrt{p} \cdot \sigma_{P}$

Phenotypic Index

The response of selection based on phenotypic data depends on the trait to be improved (e.g. gain for yield based on the index); the total response being the sum of all sub-responses of each trait included in the index:

$\mathrm{R}_{\mathrm{lp}}=\sum_{\mathrm{i}} \mathrm{i} \cdot \sigma_{\mathrm{gPi}} \cdot \mathrm{r}_{\mathrm{g}}\left(\mathrm{P}_{\left.\mathrm{i} ; \mathrm{l}_{\mathrm{p}}\right)}\right.$

If we consider one trait; let's say $\mathrm{P}_{1}$, then:

$\mathrm{R}_{\mathrm{lp} 1}=\mathrm{i} \cdot \sigma_{\mathrm{gP} 1} \cdot \mathrm{r}_{\mathrm{g}}\left(\mathrm{P}_{1} ; \mathrm{I}_{\mathrm{P}}\right)$

with $r_{g}$ the genotypic correlation between trait 1 and the phenotypic index and is expressed:

$r_{g}\left(P_{1} ; I_{P}\right)=\frac{\operatorname{COV}_{g}\left(P_{i} ; I_{P}\right)}{\sigma_{g} P_{1} \cdot \sigma_{l P}}$

According to Baker and based on the equation of the phenotypic index (2):

$\operatorname{Cov}_{g}\left(P_{1} ; l\right)=a_{1} \cdot h_{1}^{2} \cdot \sigma_{g P 1}^{2}+a_{2} \cdot h_{2}^{2} \cdot \operatorname{Cov}_{g}\left(P_{i} ; P_{2}\right)+\ldots+a_{m} \cdot h_{m}^{2} \operatorname{cov}_{g}\left(P_{i} ; P_{m}\right)$

Since the $\mathrm{m}$ traits used to construct the index were considered independent, the covariance among them is 0 ; which is then reducing the equation for a single trait improvement to:

$\operatorname{Cov}_{g}\left(P_{1} ; l\right)=a_{1} \cdot h_{1}^{2} \cdot \sigma_{g P 1}^{2}$

$\operatorname{Cov}_{g}\left(P_{i} ; l\right)=\sum_{i} a_{i} \cdot h_{i}^{2} \cdot \sigma_{g P i}^{2}$ for responses of selection of all traits 
With the assumption of uncorrelated traits composing the index and that the heritability is the ratio of genotypic to phenotypic variances, the standard deviation of the index is determined as:

$$
\sigma_{1}=\sqrt{\sum_{i} a_{i}^{2} \cdot h_{i}^{2} \cdot \sigma_{g P_{i}}^{2}} \quad \text { (details not shown) (11) }
$$

From equations (10) and (11), it is then possible to deduce the response of selection based on multiple phenotypic index:

$$
\mathrm{R}_{\mathrm{IP}}=\mathrm{i} \cdot \frac{\sum_{i} \mathrm{a}_{\mathrm{i}} \cdot \mathrm{h}_{\mathrm{i}}^{2} \cdot \sigma_{\mathrm{Pi}_{i}}^{2}}{\sqrt{\sum_{\mathrm{i}} \mathrm{a}_{\mathrm{i}}^{2} \cdot \mathrm{h}_{\mathrm{i}}^{2} \cdot \sigma_{\mathrm{Pi}}^{2}}}
$$

If the selection was considered to be done only for one trait, the response will be:

$$
R_{I P}=i \cdot \frac{a_{i} \cdot \sigma_{p}^{2} \cdot h^{2}}{a_{i} \cdot \sigma_{P} \cdot h}=i \cdot \sigma_{P} \cdot h
$$

Thus, the relative efficiency of marker assisted selection for 1 trait expressed by dividing equations (8) and (13) (derived from the generalized equation (7) and (12)) is:

$\mathrm{RE}=\frac{\mathrm{R}_{\mathrm{IP}}}{\mathrm{R}_{\text {IM }}}=\frac{\mathrm{i} \cdot \sqrt{\mathrm{p}} \cdot \sigma_{\mathrm{P}}}{\mathrm{i} \cdot \sigma_{\mathrm{P}} \cdot \mathrm{h}}=\frac{\sqrt{\mathrm{p}}}{\mathrm{h}}$

$=\sqrt{\frac{\mathrm{p}}{\mathrm{h}^{2}}}$

From the two generalised equations of the responses of multiple index selection, it was then possible to re-find the accepted Lande and Thompson formula (1990). Based on the deductions above, the following generalized formula of the pure relative efficiency of MAS based on several independent traits vs. CPS on the same set of traits is proposed:

$$
R E=\frac{i \cdot \frac{\sum_{i} a_{i} \cdot \sigma_{M_{i}} \cdot \sigma_{p i} \cdot \sqrt{p_{i}}}{\sqrt{\sum_{i} a_{i}^{2} \cdot \sigma_{M i}^{2}}}}{i \cdot \frac{\sum_{i} a_{i} \cdot h_{i}^{2} \cdot \sigma_{P_{i}}^{2}}{\sqrt{\sum_{i} a_{i}^{2} \cdot h_{i}^{2} \cdot \sigma_{P i}^{2}}}}=\frac{\left(\sum_{i} a_{i} \cdot \sigma_{M_{i}} \cdot \sigma_{p_{i}} \cdot \sqrt{p_{i}}\right) \cdot\left(\sqrt{\sum_{i} a_{i}^{2} \cdot h_{i}^{2} \cdot \sigma_{P i}^{2}}\right)}{\left(\sum_{i} a_{i} \cdot h_{i}^{2} \cdot \sigma_{P_{i}}^{2}\right) \cdot\left(\sqrt{\sum_{i} a_{i}^{2} \cdot \sigma_{M i}^{2}}\right)}
$$




\section{Example}

In the present study, three unlinked putative QTL ( $p_{D S}=32 \%$ and $\left.p_{T S}=3 \%\right)$ were detected for unhardened frost tolerance. For hardened frost tolerance, two unlinked putative QTL ( $p_{D S}=13 \%$ and $p_{T S}=5 \%$ ) were detected. These four putative $Q T L$ were not overlapping (Chapter III).

The genotypic variance of unhardened frost tolerance was 5894.23 (scoreunit ${ }^{\circ} \mathrm{h}$ ) ${ }^{2}$ with a heritability of 0.67 ; and 4370.10 (scoreunit $\left.{ }^{\circ} \mathrm{C} \mathrm{h}\right)^{2}$ with a heritability of 0.66 for hardened frost tolerance. From the regression analysis of the trait on all putative QTL effects, the variance of unhardened QTL effects was 98644.37 (scoreunit $\left.{ }^{\circ} \mathrm{C} \mathrm{h}\right)^{2}$ and 39425.41 (scoreunit ${ }^{\circ} \mathrm{C}$ h) ${ }^{2}$ for hardened QTL effect s.

For both traits, economic values were set to 1 .

The developed formula of the pure relative efficiency of marker assisted selection vs. classical phenotypic selection for multiple trait selection and single trait selection (Lande and Thompson, 1990) was applied:

Relative efficiency of MAS vs. CPS

\begin{tabular}{cccc}
\hline & $\begin{array}{c}\text { Selection on the two } \\
\text { traits simultaneously }\end{array}$ & $\begin{array}{c}\text { Unhardened frost } \\
\text { tolerance }\end{array}$ & $\begin{array}{c}\text { Hardened frost } \\
\text { tolerance }\end{array}$ \\
\hline $\mathrm{p}_{\mathrm{DS}}$ & 0.60 & 0.69 & 0.44 \\
$\mathrm{p}_{\mathrm{TS}}$ & 0.24 & 0.23 & 0.28 \\
\hline
\end{tabular}

If only one experiment was conducted (instead of three), the heritability of the genotypes for the unhardened frost tolerance would expectedly be on average 0.28 and 0.36 for hardened frost tolerance. In such case, the relative efficiency of MAS vs. CPS for multiple trait selection and single trait would have been:

Relative efficiency of MAS vs. CPS

\begin{tabular}{cccc}
\hline & $\begin{array}{c}\text { Selection on the two } \\
\text { traits simultaneously }\end{array}$ & $\begin{array}{c}\text { Unhardened frost } \\
\text { tolerance }\end{array}$ & $\begin{array}{c}\text { Hardened frost } \\
\text { tolerance }\end{array}$ \\
\hline $\mathrm{p}_{\mathrm{DS}}$ & 0.87 & 1.07 & 0.59 \\
$\mathrm{p}_{\mathrm{TS}}$ & 0.35 & 0.35 & 0.38 \\
\hline
\end{tabular}

\section{References}

Lande, R., and R. Thompson. 1990. Efficiency of marker assisted selection in the improvement of quantitative traits. Genetics. 124:743-756. 


\section{Summary}

Among grain legume species, faba bean (Vicia faba L.) could reduce the dependency of the European Union on international supply of vegetable protein. In order to promote and to genetically improve the crop, large European project was initiated. The present study, as part of the project, studied faba bean tolerance to North Europe winters, major abiotic constraint in these agro-ecological regions. This research aimed to study faba bean winter-hardiness and auxiliary traits, to determine the effect of hardening on plants, to detect QTL for frost tolerance, and to study heterosis for frost tolerance.

Based on a representative sample of frost tolerant and frost susceptible faba bean genotypes, extensive field experiments enabled to identify European winter genotypes with high winter-hardiness and grain yield. GxE interaction analyses using "additive main effect and multiplicative interaction" (AMMI) showed additionally that these genotypes were stable for both traits; displaying a general adaptation to most environments. Artificial and so called provocative frost tests indicated that frost tolerance was a significant, but not an exhaustive component of winter-hardiness $\left(0.021<|r|<0.737^{\star *}\right)$. These tests enabled to identify highly frost tolerant experimental lines such as F7-95, but also European genotypes known as winterhardy either with low frost tolerance e.g. Bulldog/1 or with high frost tolerance e.g. Karl. For environments with intermediate winter strength, these artificial and provocative frost tests could be used to indirectly screen for winter-hardiness. Fatty acid content in leaves and their changes due to hardening, proline content, and membrane stability index were significantly correlated with frost tolerance, corroborating their physiological importance for the frost tolerance. Moreover, the analyses of leaves and stems revealed that unhardened oleic acid content and changes in oleic acid and in linoleic plus linolenic acid content in leaves due to hardening partly explained their frost tolerance $\left(0.347+<|r|<0.543^{\star *}\right)$. In stems, although significant changes due to hardening were observed on oleic acid (-1.77\%) and linolenic acid $(+9.06 \%)$, they were unrelated with frost tolerance.

In order to molecularly assist selection for frost tolerance and ultimately for winterhardiness, QTL analyses were performed on a population of 101 recombinant inbred lines. For all studied traits, a LOD threshold of 3.25 was used to declare putative QTL. For frost tolerance, four putative QTL were detected; two for unhardened frost 
tolerance that explained $28.3 \%$ (3.44\% after cross-validation) of its genotypic variance and two for hardened frost tolerance that explained $12.5 \%(5.22 \%$ after cross-validation). Referring to physiological traits correlated to frost tolerance, three QTL were detected for oleic acid content in unhardened leaves that explained $57.7 \%$ (37.2\% after CV) of its genotypic variance. No QTL were detected for proline and soluble sugar content with LOD threshold of 3.25. The unbiased proportion of the genotypic variance that was explained after $\mathrm{CV}$ enabled to assess realistic prospects of MAS. Thus, combined MAS was more efficient than CPS and significant gains of selection for frost tolerance could therefore be expected on large populations at first generations of selection. Additionally, favourable alleles inherited from BPL 4628 could be used to further improve frost tolerance of European winter beans. Since most released faba bean cultivars are synthetics or populations, heterosis for frost tolerance represent an important aspect. In a diallel mating scheme with four parental lines, significant heterosis was observed. However, a cross between two European lines showed no heterosis. Unless hybrids cultivars are produced, heterosis could not be fully exploited for frost tolerance. 


\section{Zusammenfassung}

Als Körnerleguminose könnte die Fababohne (Vicia faba L.) die Abhängigkeit Europas von pflanzlichem Protein-Import reduzieren. Um diese Ackerfrucht zu fördern und genetisch zu verbessern wurde ein großes europäisches Projekt initiiert. Die gegenwärtige Studie betraf als Teil dieses Projektes die Toleranz der Fababohne gegen nordeuropäischen Winterbedingungen; der Winter ist ein Hauptfaktor für abiotischen Stress in diesen agro-ökologischen Regionen. Diese Studie hatte zum Ziel, die Winterhärte der Fababohne und auch Hilfsmerkmale für Winterhärte zu studieren, den Effekt von Härtung auf die Pflanzen zu bestimmen, QTL für Frosttoleranz zu entdecken und Heterosis für Frosttoleranz zu studieren.

Umfangreiche Feldversuch mit einer repräsentativen Stichprobe von frosttoleranten und frostanfälligen Fababohnen-Genotypen erlaubten es, europäische WinterGenotypen mit hoher Winterhärte und hohem Kornertrag zu identifizieren. Genotyp x Umwelt-Interaktionsanalysen mittels „additive main effect and multiplicative interaction“ (AMMI) zeigten zusätzlich, dass diese Genotypen stabil für beide Merkmale waren; sie verfügten über eine allgemeine Adaptation an die meisten Umwelten. Künstliche und sogenannte provokative Frostprüfungen deuteten an, dass die Frosttoleranz eine signifikante aber keine erschöpfende Komponente der Winterhärte war $\left(0,021<|r|<0,737^{* *}\right)$. Diese Prüfungen erlaubten es, hochgradig frosttolerante experimentelle Linien wie F7-95 zu identifizieren, aber auch europäische Genotypen, die als winterhart bekannt sind, und die entweder eine niedrige Frosttoleranz haben wie z.B. Bulldog/1 oder eine hohen Frosttoleranz wie z.B. Karl. Mit Blick auf Umwelten mit intermediärer Winterstrenge könnten diese künstlichen und provokativen Frostprüfungen benutzt werden, um indirekt die Winterhärte zu erfassen. Der Fettsäuregehalt in Blättern und deren Änderung aufgrund von Härtung, der Prolingehalt und der Membranstabilitätsindex waren signifikant mit der Frosttoleranz korreliert, was die physiologische Bedeutung dieser Merkmale für die Frosttoleranz bestätigt. Darüber hinaus zeigte die Analyse von Blättern und Stängeln, dass der Ölsäuregehalt ohne Härtung und die Veränderung im Ölsäuregehalt und im Linolsäure- plus Linolensäuregehalt in Blättern aufgrund von Härtung deren Frosttoleranz teilweise erklärte $\left(0,347^{*}<r<0,543^{\star *}\right)$. Obwohl in Stängeln signifikante Veränderung aufgrund von Härtung bei Ölsäure $(-1,77 \%)$ und 
Linolensäure $(+9,06 \%)$ beobachtet wurden, waren diese doch ohne Beziehung zur Frosttoleranz.

Um eine Auslese auf Frosttoleranz und schlussendlich auch auf Winterhärte mit DNA-Markern zu unterstützen, wurden QTL-Analysen mit einer Population von 101 sog. rekombinierten Inzuchtlinien durchgeführt. Für alle untersuchten Merkmale wurde eine LOD-Schwelle von 3,25 zur Absicherung mutmaßlicher QTL benutzt. Für Frosttoleranz wurden vier solche mutmaßliche QTL entdeckt; zwei für Frosttoleranz ohne Härtung, die 28,3\% (3,44\% nach Kreuzvalidierung) der genotypischen Varianz erklärten und zwei für Frosttoleranz mit Härtung, die 12,5\% (5,22\% nach Kreuzvalidierung) erklärten. Mit Bezug auf physiologische Merkmale die mit Frosttoleranz korreliert waren, wurden drei QTL für Ölsäuregehalt in ungehärteten Blättern entdeckt, die 57,7\% (37,2\% nach Kreuzvalidierung) der genotypischen Varianz erklärten. Für den Gehalt an Prolin und löslichem Zucker wurde mit einer LOD-Schwelle von 3,25 kein QTL entdeckt. Der unverzerrte Anteil der genotypischen Varianz der nach Kreuzvalidierung erklärt wurde erlaubte es, die Aussichten einer markergestützten Selektion realistisch zu bewerten. Es zeigte sich, dass eine kombinierte markergestützte und phänotypische Selektion effizienter wäre als eine nur phänotypische Selektion und dass somit bedeutende Selektionsgewinne für Frosttoleranz in großen Populationen in den ersten Selektionsgenerationen erwartet werden können. Zusätzlich könnten günstige Allele die von BPL4628 vererbt werden benutzt werden, um die Frosttoleranz europäischer Winterbohnen weiter zu verbessern. Da die meisten zugelassenen Fababohnensorten synthetische oder sonstige Populationssorten sind, stellt Heterosis für Frosttoleranz einen wichtigen Aspekt dar. In einem diallelen Schema mit vier elterlichen Linien wurde signifikante Heterosis beobachtet. Eine Kreuzung zwischen zwei europäischen Linien zeigte allerdings keine Heterosis. Solange keine Hybridsorten produziert werden kann Heterosis für Frosttoleranz nicht vollständig ausgenutzt werden. 


\section{Résumé}

En ce début du XXI ième siècle, l'Europe dépend fortement du marché international pour subvenir à ses besoins en protéines d'origine végétale. La teneur en protéine de la féverole (Vicia faba L.) étant en moyenne de $30 \%$, cette culture devrait permettre de réduire les importations de soja. Afin de promouvoir la féverole, un vaste projet Européen a été initié visant à améliorer la qualité nutritionnelle des graines, la résistance aux stress biotiques et abiotiques, et le développement d'outils moléculaires. Dans les pays Nord Européens, la féverole est principalement cultivée comme culture printanière. La faible capacité des cultivars à survivre à l'hiver représente la majeure limitation du semis en automne. Des études ont toutefois révélé la supériorité des génotypes d'hiver sur des génotypes de printemps pour les rendements en grain et en protéine, mais également une meilleure stabilité au fil des années et des localités. L'objectif de cette recherche fût donc l'étude de la capacité de la féverole à survivre à l'hiver et de ses composantes directes et indirectes, la détermination de l'effet de l'endurcissement à l'échelle de la plante, la détection de QTL associés à la tolérance au froid, et finalement l'estimation de l'hétérosis pour cette même tolérance.

En se basant sur un échantillonnage représentatif de génotypes de féverole tolérants et sensibles aux basses températures, les essais au champ ont permis d'identifier cinq génotypes Européens ayant une forte capacité à survivre à l'hiver et un rendement en grain élevé; parmi lesquels Hiverna/2 et Bulldog/1. L'analyse de l'interaction GxE par l'AMMI («Additive Main effect and Multiplicative Interaction») a permis de révéler la stabilité de ces génotypes pour ces deux traits. Les expériences en milieu contrôlé ont montré que la tolérance au froid était une composante principale mais non exhaustive de la capacité à survivre à l'hiver $(0.021<|r|<$ $\left.0.737^{\star *}\right)$. Ces analyses ont également permis de confirmer la tolérance élevée au froid de génotypes Européens d'hiver (e.g. Karl) mais aussi de révéler la tolérance de certaines lignées expérimentales (e.g. F7-95) et la sensibilité de génotypes Européens d'hiver (e.g. Bulldog/1). Les changements de teneur en acides gras et en proline, ainsi que la stabilité de la membrane cellulaire étaient significativement corrélés à la tolérance au froid. Par ailleurs, la composition en acides gras des feuilles était plus corrélée à la tolérance au froid $\left(0.347+<|r|<0.543^{\star *}\right)$ que celle des tiges. Bien que des effets significatifs aient été observés dans les tiges pour les 
acides oléique $(-1.77 \%)$ et linolénique $(+9.06 \%)$, ils n'étaient pas corrélés à la tolérance au froid.

Afin d'assister la sélection pour la tolérance au froid et par conséquent la capacité à survivre à l'hiver, une analyse QTL a été réalisée sur une population de lignées recombinantes. Le seuil du LOD score a été fixé à 3.25 pour déclarer des QTL putatifs. Avant endurcissement, deux QTL ont été détectés expliquant 28.3\% (3.44\% après cross-validation) de la variance génotypique. Après endurcissement, deux autres QTL ont été détecté expliquant $12.5 \%$ (5.22\% après cross-validation). Concernant les traits physiologiquement corrélés à la tolérance au froid, trois QTL ont été détecté pour la teneur en acide oléique avant endurcissement, expliquant $57.7 \%$ (37.2\% après CV) de sa variance génotypique. En revanche, aucun QTL n'a été détecté pour la teneur en proline et en sucres solubles. La proportion expliquée après CV fût utilisée pour estimer les gains réalisables par la sélection assistée par marqueurs moléculaires (MAS). Ainsi, la MAS combinée s'est avérée être plus efficace que la sélection phénotypique seule; laissant ainsi entrevoir une réponse significative à la sélection pour la tolérance au froid sur de larges populations. En outre, l'introgression des allèles favorables provenant de la lignée exotique BPL 4628 à une lignée Européenne d'hiver (e.g. Hiverna/2) pourrait permettre l'amélioration de sa tolérance aux basses températures. Dans les programmes d'amélioration de la féverole, la majorité des cultivars étant des populations ou des variétés synthétiques, l'hétérosis représente donc un aspect important. Basé sur un plan de croisement diallèle de quatre lignées, un effet significatif d'hétérosis a été observé. L'absence d'hétérosis entre deux lignées Européennes laisse à penser que ces deux lignées partageraient la majorité des allèles favorables à la tolérance au froid. Ainsi, à moins que des cultivars hybrides soient produits, l'hétérosis ne pourrait être complètement exploité. 


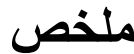

حاليا وفي بداية القرن الواحد والعشرين، تعتمد أوروبا أساسيا على السوق العالمي لتوفير حاجياتها من البروتينات النباتية، بما أن فصيلة الفول تحتوي على معدل من 30\% من البرونينات، فاستعمال هذه الزر اعة ستمكن من تخفيض إستير اد فول الصويا. لتشجيع زراعة الفول، تم قيادة مشروع أروبي واسع يسدد إلى تحسين الجودة الغذائية لحبات الفول، مقاومة الظروف الحيوية والاحيوية وتطوير تقنيات المعلمات الور اثية. يزرع الفول في بلدان الثمال الأروبي آساسيا كزراعة ربيعية. تعتبرطاقة الفول الضعيفة على مقاومة برودة الثتاء عائقا كبير الزراعة الفول الثتنوي. بالر غم من ذللك، أثنتت دراسات سابقة، تفوق أصناف الفول الثنوي على أصناف الفول الربيعي من حيث المردودية، محتوى البروتينات وكذا القدرة على الثبات باختلاف السنو ات و المو اقع. ارتكز هدف الدراسة الحالية على تحليل قدرة الفول على مقاومة فصل الثتاء، تحليل العناصر المباشرة و الغير المباثرة لهذه المقاومة، حسم تأثير التقوية "Hardening" على ع مستوى النبتة، كثف ال QTL المرتبطة بمقاومة واحتمال البرد و أخير ا تقييم مستوى الهجن (Heterosis) لخاصية احتمال البرد. اعتمادا على تجارب حقلية لعينة نمودجية لفصائل الفول المتحملة والمتأثرة بالدراجات الحرارية المنخفضة، تم التعرف على خمس أصناف أروبية ذات قدرة عالية على مقاومة برودة الثتاء وذات مردودية عالية ـ تتواجد Hiverna/2 و Bulldog من بين هاته الأصناف. مكن تحليل تفاعل الفصائل مع البيئة باستعمال "AMMI" من كثف ثبات الاصناف بالنسبة لمقاومة برودة الثتاء و المردودية. أظهرت التجارب المقادة في الوسط المراقب أن تحمل البرد يمثل عنصر ا أساسي لكن غير مطلق للقدرة على مقاومة فصل الثتاء (0.737) 
مكنت هذه التحاليل أيضا من تأكيد التحمل العالي للأصناف الأروبية للبرد (مثلKarl ). تم كثف التحمل العالي للبرد لبعض السلالات النقية التجاربية (مثل: F7-95) وكذا تأثر بعض الأصناف الأروبية (مثل: / / Bulldog ). الإختلاف في محتوى الأحماض الدهنية (acides gras) و البرولين وكذا ثبات الغشاء الخلوي مرتبطون بشكل كبير بالبرد. مقارنة مع الساق، ارتبط محتوى الأوراق بالأحماض

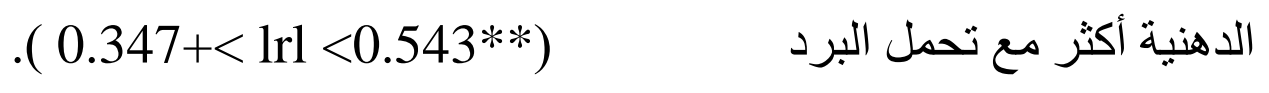

لتدعيم الإنتقاء لخاصية تحمل البرد وكذا مقاومة فصل الثتاء، نم قيادة تحاليل لـ QTL على لثى مستوى مجموعة من السلالات النقية. حددت عتبة "LOD score" إلى 3.25 لإعلان

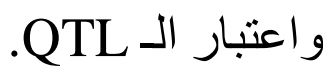
تم كثف اثنان QTL يفسران 28.3 من التغيرات الور اثية قبل التقوية. بعد التقوية، تم كثف اثنان QTL آخرين يفسران 12.5\% بالنسبة للخصائص الفسيولوجية المرتبطة بتحمل البرد، تم الكثف على ثلاث QTL مفسرة

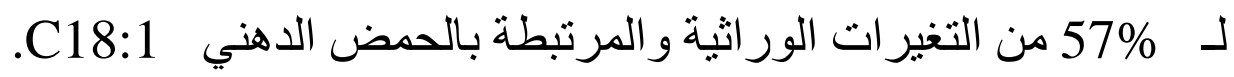
دلت النتائج على أن تقنية Marker Assisted Selection) MAS) أكثر فعالية مقارنة مع الإنتقاء الظاهري. نقل الأحاليل الإيجابية الناجمة عن السلالة النقية BPL 4628 إلى سلالة نقية أوروبية مثل Hiverna/ 2 قد بمن من تحسين قدرتها على تحمل الدرجات

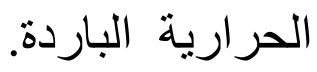
بما أن معجم الأصناف المستعملة في إطار برامج تحسين الفول ترتكز على الأصناف التركيية والعشائر، فإن مستوى الهجن يشكل عنصرا أساسيا. غياب الهجن بين سلالتين نقيتين أروبيتين يدل على أن هاتين السلالتين تثاركان معجم الأحاليل الإيجابية لخاصية تحمل البرد، وبذلك لايمكن استعمال الهجن بشكل مطلق إلا بإنتاج أصناف هجنية. 


\section{Acknowledgements}

This work was supported by funds from the commission of the European Communities, specific Research Program Quality of Life and Management of Living Resources, QLK5-2001-02307. It does not necessarily reflect its views and in no way anticipates the Commissions' future policy in this area.

I acknowledge the NPZ-Lembke Company for providing me a scholarship during these three years and for financing part of my staying at Cordoba, Spain and the DSV Company for financing my participation to an International Conference (PMAC).

I would like to express all my gratitude and my thanks to my supervisor Prof. Dr. Wolfgang Link for his excellent supervision and for our scientific and non-scientific discussions. I thank as well Prof. Mohammed Sadiki for presenting me to Prof. Dr. Link and for accepting to be my co-referee.

I thank Dr. Ana Maria Torres for inviting me at the Junta de Andalusia in Cordoba to develop a linkage map and QTL for frost tolerance, for supervising me during my staying there, and for helping and supporting me when I was coming at her office with non good looking gels. I am thankful to Dr. Christiane Balko for providing me results on membrane stability and proline and sugar content in leaves of my faba bean material, and to Johanna Winkler, Miroslav Hybl, Lea Narits, and Olaf Sass for conducting field experiments at their location.

I am grateful to Dr. Fred Stoddard who kindly reviewed several of my manuscripts before submission.

I thank Regina Martsch and Ulrike Kierbaum for their perfect assistance in the field and in the frost chamber, but also for all their friendship.

I am thankful to my colleague and wife Lamiae Ghaouti for her help and support during these three years. I thank also Susanne Voges for all her professional and personal support during my staying in Göttingen.

I am thankful to Mladen Radoev who extremely helps me in the understanding of molecular tools, but also for sharing with me most of my good times at Göttingen.

It is also my pleasure to thank Prof. Dr. H. Becker, Dr. C. Möllers, Dr. W. Ecke, Dr. Sabine Von Witzke-Ehbrecht and Dr. Friedrich Kopisch-Obuch for all formal and informal discussions; and all colleges of Institute and friends for all their support. 


\section{Curriculum Vitae}

\section{Mustapha ARBAOUI}

Date of birth: 30.03.1979

Marital Status: Married

Nationality: Moroccan

Von-Siebold-Str 8, 37075, Göttingen, Germany

Tel: +49 (0) 17623564349

E-Mail: mustaphaarbaoui@hotmail.com

\section{Education}

2007: Doctor Diploma in agronomy, specialised in plant breeding at the Crop Sciences Department at the Georg-August University in Göttingen (Germany).

The research aims to study the winterhardiness of several faba bean genotypes through field trials, experiments in artificial conditions (frost chamber), and laboratory analyses (leaves and stem fatty acids analyses; and QTL mapping). This study was part of the European project: faba bean breeding for sustainable agriculture (Eufaba). 2003: Master diploma. Engineer in agronomy, specialized in plant breeding at the Agronomic and Veterinary Institute (IAV-HassanlI), Rabat. Morocco (Bac+6).

The research aimed to analyze the genetic diversity of faba bean in North Morocco in order to establish in situ conservation approaches. This study was part of the research conducted by the IPGRI (International Plant Genetic Resources Institute) on genetic diversity maintain.

2001: Diploma of General Agronomy at the Agronomic and Veterinary Institute (IAVHassanll), Rabat. Morocco. (Bac+4)

1997: Diploma of Scientific Baccalaureate at Lycée Lyautey in Casablanca, French school.

\section{Professional experiences}

03.2004 to 06.2007: Research assistant at the Department of Crop Sciences of Göttingen (Georg-August University) in Germany. Tasks assigned encompassed the project management, trials planning and statistical and empirical analyses, as well as the contribution to national and international scientific meetings. 


\section{Training}

2000: Training on study of managing and analyzing agricultural systems of one specific Moroccan farm for one month.

1999: Training for nature and rural area discovery for three weeks in Morocco.

1998: Training as a worker in a French farm for two months and half.

\section{Publications}

- Sadiki, M., M. Arbaoui, L. Ghaouti, and D. Jarvis. 2004. Seed exchanges and supply systems and on farm maintenance of crop genetic diversity. A case study: faba bean in Morocco. In 'Seed System and Crop Genetic Diversity On Farm' Jarvis D.I., R. Sevilla Panizo, J.L. Chavez-Servia, and T. Hodgkin, Editors.

- Arbaoui, M., and W. Link. 2005. Three approaches to screen faba bean (Vicia faba L.) for winter hardiness. In International Workshop on faba bean breeding and agronomy. Cordoba. Spain. 25-27 October 2006. Junta de Andalucia Editors.

- Stoddard, F., W. Link, M. Arbaoui, and H. Khan. 2007. Faba bean breeding for drought and frost tolerance. Grain Legumes. 48:20-21.

Prepared for publication:

- Arbaoui, M., C. Balko, and W. Link. 2007. Study of faba bean (Vicia faba L.) winterhardiness and development of screening methods for frost tolerance. Article prepared for "Crop Science".

- Arbaoui, M., and W. Link. 2007. Effect of hardening on frost tolerance and fatty acid composition of leaves and stems of a set of faba bean (Vicia faba L.) genotypes. Accepted in "Euphytica".

- Arbaoui, M., A.M. Torres, and W. Link. 2007. Quantitative trait loci of frost tolerance ans physiologically related trait in faba bean (Vicia faba L.). Article prepared for submission.

- Arbaoui, M., and W. Link. 2007. Study on heterosis for frost tolerance in faba bean (Vicia faba L.). Short communication prepared for submission. 


\section{Informatics and statistical knowledge}

- Average in Pascal program

- Excellent in Microsoft Excel, Word, Power Point

- Very good in 2 statistical software (PLABSTAT, STATITCF) and average in SAS and $\mathrm{R}$

- Good in MAPMAKER 3.0 and PLABQTL

\section{Languages knowledge}

- Arabic: Mother tongue

- French: Very good

- English: Good

- German: Average

\section{References}

- Prof. Dr. Wolfgang Link

Professor at the department of Crop Sciences at the Georg-August University in Göttingen.

Von-Siebold Str. 8, 37075, Göttingen, Germany

Email: wlink@gwdg.de

Tel.: +49 (0) 551394353

- Prof. Mohamed Sadiki

Head of the Plant Breeding Department, and Director of the research and the doctoral education at the Institut Agronomique et Vétérinaire Hassan II

BP6202 Rabat Instituts, 10101, Rabat, Morocco

Email: m.sadiki@iav.ac.ma

Tel.: +212 (0) 37774869

- Prof. Dr. Heiko Becker

Head of the department of Crop Sciences at the Georg-August

University in Göttingen.

Von-Siebold Str. 8, 37075, Göttingen, Germany

Email: hbecker@gwdg.de

Tel.: +49 (0) 551394381 